\title{
Phytogeographic distribution groups of benthic marine algae in the North Atlantic Ocean. A review of experimental evidence from life history studies
}

\author{
C. van den Hoek \\ Department of Systematic Botany, Biological Centre, The University; \\ P.O. Box 14, 9750 AA Haren, Groningen, The Netherlands
}

\begin{abstract}
Experimentally determined lethal temperatures and temperatures limiting growth or reproduction in the life histories of 15 benthic algal species were used to infer possible phytogeographic boundaries in the North Atlantic Ocean. These appeared to correspond closely with phytogeographic boundaries based on distribution data. Many boundaries appeared to be of a composite nature. For instance, the southern boundary of Nemalion helminthoides is interpreted as a "southern reproduction boundary" on the N. Atlantic E. shore and a "southern lethal boundary" on the N. Atlantic W. shore. The northern boundary on both sides of the ocean is a "northern reproduction boundary". $N$. helminthoides is a typical representative of the "amphiatlantic temperate distribution group", to which seven other of the fifteen investigated species belong (Chondrus crispus, Desmarestia aculeata, D. viridis, Monostroma grevillei, Acrosiphonia "arcta" with a comparable composite southern boundary; Rhodochorton purpureum with a "southern lethal boundary"). Polysiphonia ferulacea and Dictyota dichotoma are treated as representatives of the "amphiatlantic tropical-to-warm-temperate distribution group", and $P$. denudata as representative of the "amphiatlantic tropical-to-temperate group". P. harveyi belongs to the N.E. American temperate group and is bounded by a "northern reproduction boundary" and a "southern reproduction boundary". This is one of the very few species endemic to N.E. America. This poor endemism is ascribed to the vast adverse sediment shores and their additional acting as barriers to glacial northsouth displacements of the flora; it is not related to the wide annual temperature fluctuations $\left(>20^{\circ} \mathrm{C}\right)$ typical for N.E. America. The temperate algal flora of Japan, however, which is extremely rich in endemic species is subject to equally wide annual temperature fluctuations. Bonnemaisonia hamifera is such a Japanese endemic, which has been accidentally introduced into the North Atlantic Ocean where its life history seems to be disrupted: it is maintained mainly by vegetative propagation of the heteromorphic tetrasporophyte. The species of the "warm temperate Mediterranean-Atlantic group" are probably too stenothermous for life on N.E. American shores; they need annual temperature fluctuations $<20^{\circ} \mathrm{C}$. Acrosymphyton purpuriferum seems to belong to this group, but arguments are presented to unite this species with $A$. caribaeum and to range it under the "amphiatlantic tropical-to-warm-temperate group". Clathromorphum circumscriptum belongs to the "Arctic distribution group" and has a "southern reproduction boundary" across the ocean along the $3{ }^{\circ} \mathrm{C}$ February isotherm. This species is able to survive temperatures of about $20^{\circ} \mathrm{C}$. Five amphiequatorial temperate species discussed in this paper and four in another related paper have similar maximum winter temperatures of $14-17^{\circ} \mathrm{C}$ (mean monthly values) allowing reproduction. Their amphiequatorial distribution can be explained by assuming similar low temperatures in the euphotic zone along E. Pacific and E. Atlantic equatorial coasts i.e. in narrow inshore belts of intensified upwelling during the presumably intensified glacial circulation of the ocean gyres.
\end{abstract}




\section{INTRODUCTION}

A recently finished revision (van den Hoek, 1981) and an earlier published one (van den Hoek, 1963) of the genus Cladophora (Chlorophyceae) have offered an opportunity to unravel the hitherto confused distribution patterns of 42 species of this genus in the North Atlantic Ocean (van den Hoek, 1979). These 42 species could be assigned to eight phytogeographic distribution groups which apparently had a general applicability to the marine algal flora of the North Atlantic Ocean (van den Hoek, 1982), and hypotheses were formulated about the nature of the phytogeographic boundaries of these distribution groups.

In principle, it is possible to test hypotheses about the nature of phytogeographic boundaries of individual benthic algal species by means of experimental studies on the environmental regulation of their life histories. A number of recent studies on the environmental regulation of life histories were, in general, not devised to answer questions on phytogeographic problems. Consequently the information contained in them is mostly too incomplete to solve such problems. Nonetheless, they contain a wealth of relevant information. Part of this information has been discussed elsewhere (van den Hoek, 1981), and part of it will be reviewed in the present paper.

\section{BASIC GEOGRAPHIC DISTRIBUTION GROUPS IN THE NORTH ATLANTIC OCEAN}

The above mentioned eight distribution groups will be described below, together with two additional ones.

(1) The amphiatlantic tropical-to-warm temperate group with a northeastern extension (Fig. 1). Species of this group are entirely or

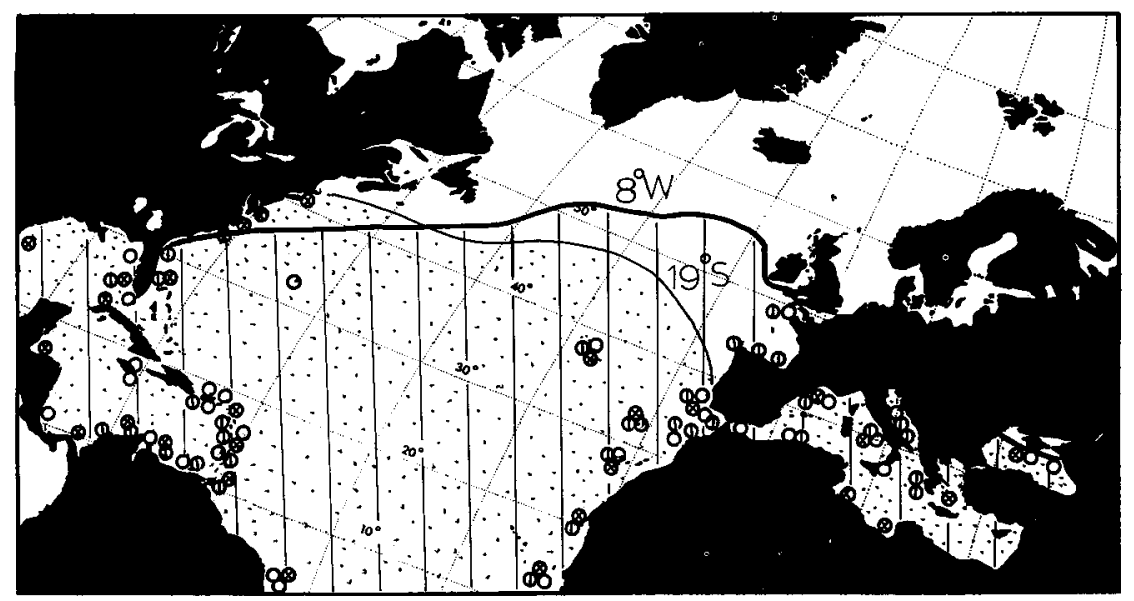

Fig. 1. The distribution of Cladophora prolifera (D), Cl. coelothrix $(0)$ and Hypnea musciformis $(\otimes)$ in the North Atlantic Ocean. 1. (hatched): the amphiatlantic tropical-to-warm temperate group with a northeastern extension (Cl, coelothrix type). 2 (stippled): the amphiatlantic tropical-to-warm temperate group with a northwestern extension (Hypnea musciformis type). $8^{\circ} \mathrm{W}=8^{\circ} \mathrm{C}$ winter (February) isotherm. $19^{\circ} \mathrm{S}=19^{\circ} \mathrm{C}$ summer (August) isotherm 
nearly restricted to the tropics in America and extend more or less far into the temperate zone in Europe. Cladophora coelothrix and $\mathrm{Cl}$. prolifera are examples. Their northern boundary is near the $8^{\circ} \mathrm{C}$ February isotherm. This suggests that both species are limited to the north by lethal winter temperatures of the surface water. At least 50 species (on a total of c. 580 considered in a phytogeographic study of the N. Atlantic Ocean, see van den Hoek, 1979) seem to belong to this distribution group on the basis of distribution data. Experimental evidence supports the hypothesis that the northern boundary of one species of this group, Gracilaria foliifera, does indeed follow the $8^{\circ} \mathrm{C}$ February isotherm, which can be considered as a "lethal boundary" (McLachlan \& Edelstein, 1977; van den Hoek, 1982). In another species of this group, Centroceras clavulatum, the northern boundary was set by a combination of a summer isotherm in Europe (determined by the lowest temperature allowing growth) and a winter isotherm in America (determined by the lethal winter temperature) (van den Hoek, 1982).

(2) The amphiatlantic tropical-to-warm temperate group with a northwestern extension (Fig. 1). The sole example, Hypnea musciformis, has a clearly more northern distribution in North America than in Europe. This is probably caused by the fact that $H$. musciformis needs a high minimum summer temperature for its growth, but can at the same time survive very low winter temperatures (down to $\mathrm{c} .-1{ }^{\circ} \mathrm{C}$ ).

(3) The amphiatlantic tropical-to-temperate group (Fig. 2). The northern limit of the example, Cladophora vagabunda, follows approximately the $12{ }^{\circ} \mathrm{C}$ summer isotherm, which suggests that this limit is determined by the minimum summer temperature allowing sufficient growth and reproduction. On the basis of distribution data, at least fifteen species (on a total of c. 580 considered in a phytogeographic study of the N. Atlantic Ocean; see van den Hoek, 1979) can probably be attributed to this group, with northern boundaries along the $15^{\circ} \mathrm{C}$ to $12^{\circ} \mathrm{C}$ summer isotherms. Sphacelaria rigidula Kütz. ( $=S$. furcigera Kütz.) has the same distribution as Cl. vagabunda. Its northern boundary, the $12^{\circ} \mathrm{C}$ summer isotherm, is determined by the lowest summer

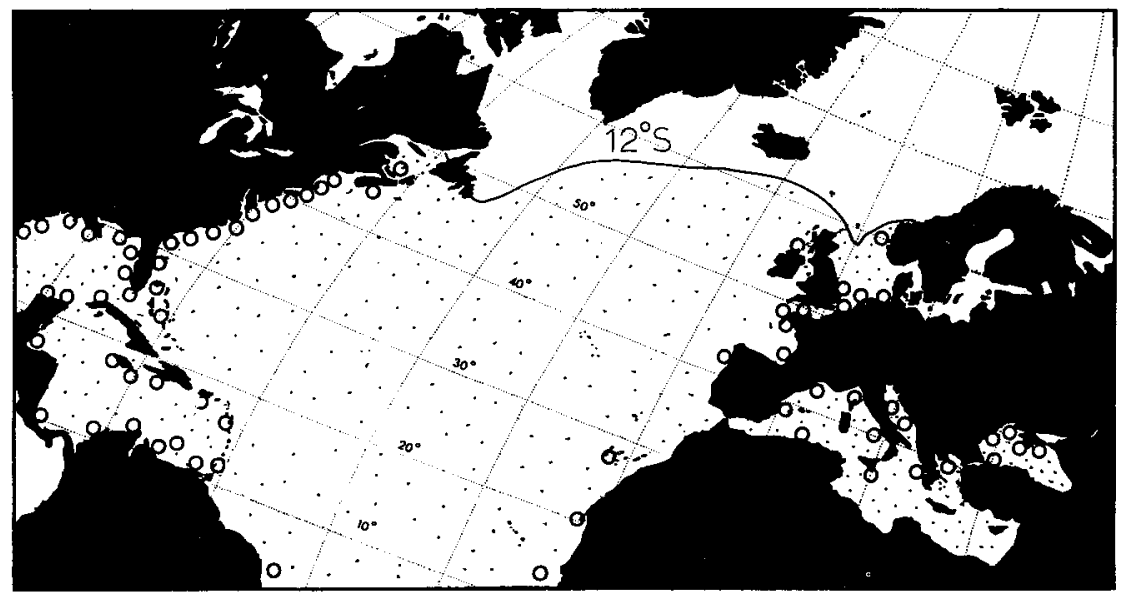

Fig. 2. The distribution of Cladophora vagabunda ( $\mathrm{O}$ and stippled area) in the North Atlantic Ocean: the amphiatlantic tropical-to-temperate group (Cladophora vagabunda type) 
temperature allowing formation of propagules (van den Hoek, 1982). This boundary is valid on a world wide scale.

$(4,5)$ The amphiatlantic temperate group; with a southern boundary near a summer isotherm (4) and near a winter is otherm (5) (Fig. 3). Both Cladophora rupestris and $\mathrm{Cl}$. albida have northern boundaries approaching August isotherms (the $5^{\circ} \mathrm{C}$ and $12{ }^{\circ} \mathrm{C}$ isotherms, respectively). This suggests that they are limited to the north by minimum summer temperatures allowing sufficient growth and/or reproduction. The southern boundary, however, of $\mathrm{Cl}$. rupestris is near the $20^{\circ} \mathrm{C}$ summer isotherm, and of $\mathrm{Cl}$. albida near the $14^{\circ} \mathrm{C}$ winter isotherm. This suggests that $C l$. rupestris is limited to the south by a lethal summer temperature; and Cl. albida by a winter temperature which is sufficiently low to permit growth and/or reproduction. At its southern boundary in Texas Cl. albida is a winter species, at its northern boundary a summer species. At least 40 species (on a total of $c$. 580 considered in a phytogeographic study of the N. Atlantic Ocean, see van den Hoek, 1979) can be attributed to group 4 on the basis of distribution data (van den Hoek, 1979, 1982). Their southern boundaries seem to follow the $17^{\circ} \mathrm{C}-23^{\circ} \mathrm{C}$ summer isotherms. The northern boundary of Callithamnion hookeri follows the $10^{\circ} \mathrm{C}$ summer isotherm, and this corresponds with a minimum temperature of c. $10^{\circ} \mathrm{C}$ allowing sufficient growth. The southern boundary at the $25^{\circ} \mathrm{C}$ summer isotherm corresponds with a lethal temperature of c. $27^{\circ} \mathrm{C}$ (Edwards, 1979; van den Hoek, 1982). In a comparable way, Dumontia contorta ( $=D$. incrassata) and Laminaria saccharina have southern boundaries along the $19^{\circ} \mathrm{C}$ summer isotherm corresponding with somewhat higher lethal temperatures (van den Hoek, 1982; Rietema \& Klein, 1981; Rietema, in prep.; Lüning, 1980). The southern boundary of $L$. digitata, however, follows approximately the $10^{\circ} \mathrm{C}$ winter isotherm in Europe, which corresponds with the highest winter temperature allowing sufficient maturation of the female gametophyte. In America the southern boundary is at the $19^{\circ} \mathrm{C}$ summer isotherm and this corresponds with a lethal temperature of c. $21^{\circ} \mathrm{C}$ (van den

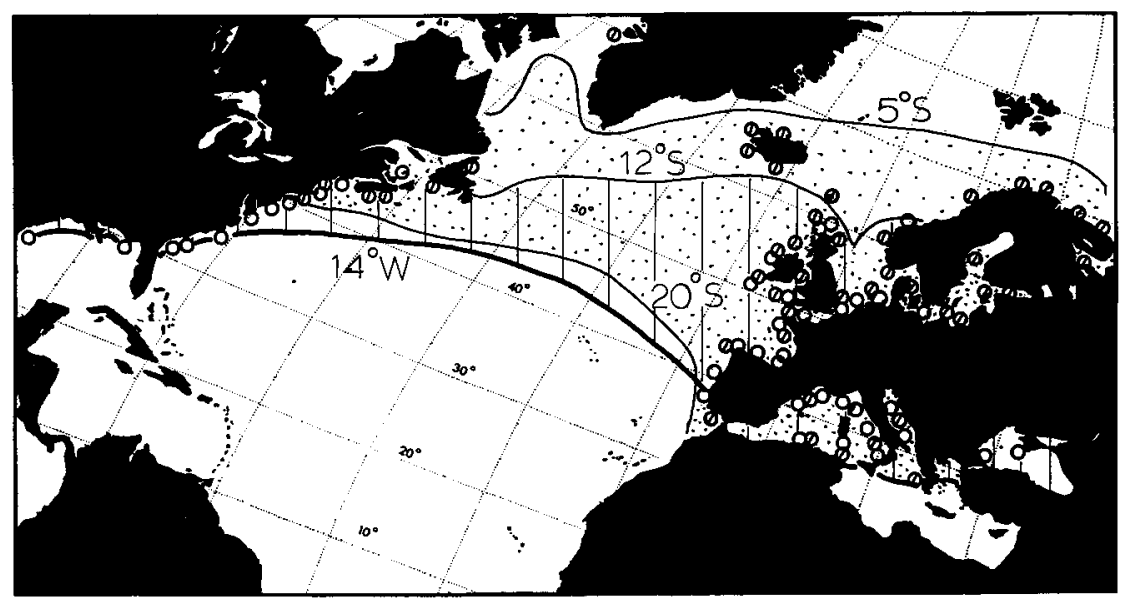

Fig. 3. The distribution of $C l$. rupestris $(\Theta$, stippled area: the amphiatlantic temperate group with a southern boundary near a summer isotherm). The distribution of $C l$. albida $(\mathrm{O}$, hatched area: the amphiatlantic temperate group with a southern boundary near a winter isotherm) 
Hoek, 1982; Lüning, 1980). A comparatively small number of at least twelve benthic algal species (out of c. 580 in the N. Atlantic Ocean considered in a phytogeographic study) can be assigned to the distribution group 5 .

Scytosiphon lomentaria and Petalonia fascia are both limited to the south by the $17^{\circ} \mathrm{C}$ winter isotherm. This corresponds with the highest temperature of c. $20^{\circ} \mathrm{C}$ which allows, in winter, the initiation of erect thalli from crustose thalli in southern ecotypes (Lüning, 1981a, 1981b; van den Hoek, 1982).

(6) The tropical Western Atlantic group (Fig. 4). Cladophora catenata is an example. So far, no experimental data are available to explain the temperature responses of the species in this group, which embraces at least 250 species of the 450 inhabiting the tropical Western Atlantic region (and of the c. 580 species in the $N$. Atlantic Ocean considered in a phytogeographic study, cf. van den Hoek, 1979) which were considered in the context of phytogeographic comparisons (van den Hoek, 1975).

(7) The American tropical-to-temperate group (Fig. 4). Only five species can be presently assigned to this group with some certainty. Gracilaria tikvahiae is limited to the North (in shallow embayments of the southern Gulf of St. Lawrence) by summer temperatures above $20^{\circ} \mathrm{C}$ allowing sufficient growth, and it is at the same time capable of surviving $-2{ }^{\circ} \mathrm{C}$ below winter ice cover (Edelstein et al., 1976; Bird et al., 1977a, b, 1978; McLachlan and Edelstein, 1977; Edelstein, 1977; von den Hoek, 1982). Three of the four other species (e.g., Grinnellia americana) prefer similar shallow embayments, where they profit by high summer temperatures of up to $30^{\circ} \mathrm{C}$, but can survive freezing (van den Hoek, 1982).

(8) The N.E. American temperate group (Fig. 4). Very few species, for instance Chondria baileyana are endemic to the N.E. American shores between $30^{\circ} \mathrm{N}$ and $45^{\circ} \mathrm{N}$. Just like most species of the previous group, C. baileyana inhabits inshore water and embayments with wide annual temperature fluctuations. This scarcity of

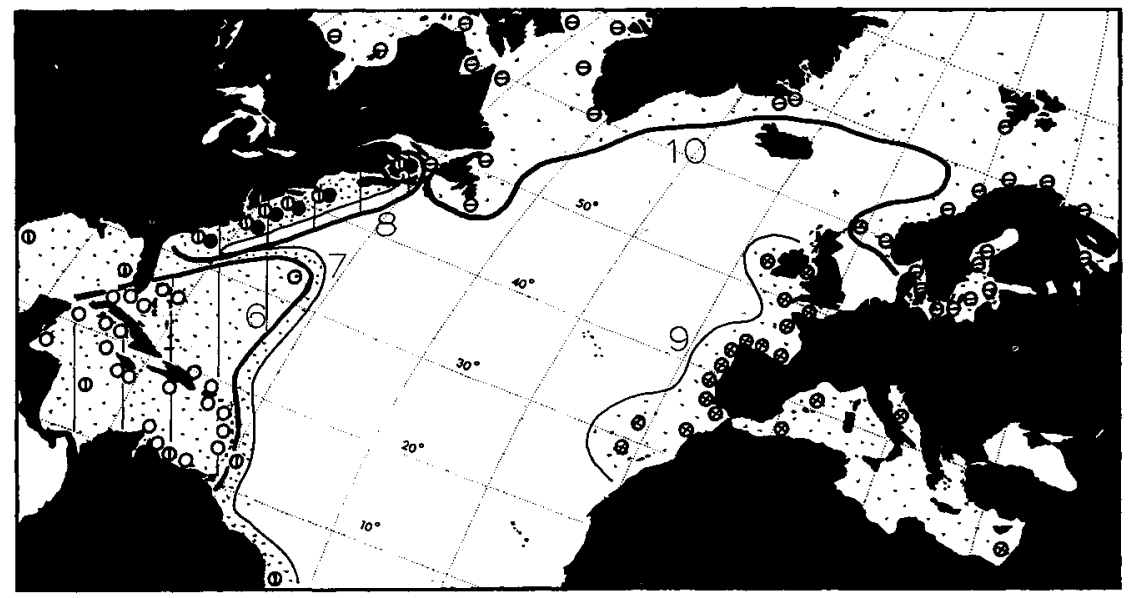

Fig. 4. The distribution of $C 1$. catenata $(0,6$ : the tropical Westem Atlantic group); Gracilaria tikvahiae $(0,7$ : the American tropical-to-temperate group); Chondria balleyana (e 8: the American temperate group); Cladophora pellucida $(\otimes, 9$; the warm temperate Mediterranean-Atlantic group); Sphacelaria arctica $(\Theta, 10$ : the Arctic group) 
endemic species in the American temperate distribution group contrasts sharply with the large number of endemic species in the algal flora of the Japanese coasts which occupy a comparable latitudinal belt between $30^{\circ} \mathrm{N}$ and $45^{\circ} \mathrm{N}$ with equally wide annual temperature fluctuations. Here 125 out of 170 "indicator species" (Funahashi, 1974) are endemic. The Japanese flora comprises in total c. 750 Chloro-, Rhodo-, and Phaeophyceae. Experimental evidence indicates that Campylaeophora hypneoides J. Ag. (Notoya, 1979) is limited to the north by the $15^{\circ} \mathrm{C}$ summer isotherm, which indicates the minimum temperature necessary for sufficient growth; and to the south by the $27^{\circ} \mathrm{C}$ summer isotherm, which corresponds approximately with a lethal temperature of $30^{\circ} \mathrm{C}$. As this species is able to survive in its northern range $-2{ }^{\circ} \mathrm{C}$, it can bridge a temperature range of $-2{ }^{\circ} \mathrm{C}$ to $30^{\circ} \mathrm{C}$. Sargassum muticum, a Japanese species which has been accidentally introduced in N.W. America und N.W. Europe, has a comparable wide temperature range. It is likely that the poverty of the endemic flora along N.E. American coasts between $30^{\circ} \mathrm{N}$ and $45^{\circ} \mathrm{N}$ can be attributed to the adverse nature of the sediment coasts to the growth of benthic macroalgae. Moreover, these adverse coasts have probably acted as barriers to north-south and south-north displacements of the benthic algal flora during glaciations and have thus caused its impoverishment and prevented successful speciation.

(9) The warm temperate Mediterranean-Atlantic group (Fig. 4). Cladophora pellucida is one of the numerous examples. At least 180 species of the 430 species inhabiting European Atlantic shores and considered in a phytogeographic comparison embracing c. 580 species in the N. Atlantic Ocean, can be attributed to this distribution group (van den Hoek, 1975, 1979). In one species, Saccorhiza polyschides (see Norton, 1977, for the regulation of its life history), the southern boundary in N.W. Africa is situated at about the $15^{\circ} \mathrm{C}$ February isotherm. This corresponds with the maximum winter temperature of $17^{\circ} \mathrm{C}$ allowing maturation of female gametophytes (at still higher temperatures they only grow vegetatively). The winter temperature lethal to female gametophytes and young sporophytes is $3^{\circ} \mathrm{C}$. The summer temperature lethal to sporophytes of $S$. polyschides is $25^{\circ} \mathrm{C}$. The corresponding lethal boundaries are the $4^{\circ} \mathrm{C}$ winter isotherm in the north and the $23^{\circ} \mathrm{C}$ summer isotherm in the south, embracing $19^{\circ} \mathrm{C}$ of mean monthly temperatures of the surface water. This maximum temperature span makes $S$. polyschides unfit for inhabiting temperate American coasts where all species must be capable of bridging temperature spans of more than $20^{\circ} \mathrm{C}$ (mean monthly temperature). This is a very obvious cause of the absence of species endemic to European coasts from N.E. American coasts (van den Hoek, 1982). S. polyschides bridges, along African and European shores, an enormous latitudinal span of $25^{\circ} \mathrm{N}$ to $65^{\circ} \mathrm{N}$. Nonetheless it is incapable of inhabiting the N.E. American coasts as a result of its temperature responses. Endemic species with still narrower latitudinal spans in Europe are probably even less fit for life on American shores than Saccorhiza polyschides.

(10) The Arctic group (Fig. 4). Sphacelaria arctica is an example which follows the general trend of Arctic species to penetrate more or less far into the cool temperate zone. About at least 20 species (on a total of 580 considered in a phytogeographic study of the N. Atlantic Ocean, see von den Hoek, 1979) can be assigned to the Arctic group on the basis of distribution data (van den Hoek, 1979). The southern boundary of Saccorhiza dermatodea is near the $4^{\circ}$ February isotherm in Europe, and the $15^{\circ} \mathrm{C}$ August isotherm in America. The $4{ }^{\circ} \mathrm{C}$ February isotherm corresponds with the 
highest winter temperature $\left(5^{\circ} \mathrm{C}\right)$ allowing sufficient maturation of the female gametophyte. The $15^{\circ} \mathrm{C}$ summer isotherm in America corresponds with a lethal temperature of $17^{\circ} \mathrm{C}$ for the sporophyte (Norton, 1977; van den Hoek, 1982). Sphacelaria arctica has also a southern boundary set, in Europe, by the maximum temperature in winter allowing reproduction (the $4^{\circ} \mathrm{C}$ winter isotherm); and, in America, by a lethal summer temperature (the $16^{\circ} \mathrm{C}$ August isotherm). These boundaries allow S. arctica to inhabit the Baltic Sea with winter temperatures lower than $4^{\circ}$ and summer temperatures lower than $16^{\circ} \mathrm{C}$ in the greatest part. Apparently $S$. arctica can tolerate salinities as low as $5 \%$ (van den Hoek, 1982).

\section{NEW EVIDENCE FROM LIFE HISTORY STUDIES IN SUPPORT OF THE BASIC GEOGRAPHIC DISTRIBUTION GROUPS}

When one tries to extract phytogeographically relevant information from studies on life histories, one should realize that the species may be confronted with at least the following boundaries corresponding with various types of limiting temperature conditions which should all be checked when perusing the results of the above studies. In essence, the significance of these boundaries has been previously stressed by Hutchins (1947):

(1) The "northern lethal boundary" corresponds with the lowest winter temperature which a species can survive for a period of c. $1 / 2-1$ month. (2) The "northern growth boundary" corresponds with the lowest summer temperature which, in a period of several months, allows sufficient growth. (3) The "northern reproduction boundary" corresponds with the lowest summer temperature which in a period of several months allows sufficient reproduction. Often "sufficient growth" ends with reproductive maturation but in many cases the formation of reproductive structures is governed by other temperatures than those governing growth. (4) The "southern lethal boundary" corresponds with the highest summer temperature which a species can survive during a period of $1 / 2-1$ month. (5) The "southern growth boundary" corresponds with the highest winter temperature which, in a period of several months, allows sufficient growth. (6) The "southern reproduction boundary" corresponds with the highest winter temperature which, in a period of several months, allows sufficient reproduction.

For species with an alternation of generations the six boundaries described above should be determined in principle for both generations. However, in species with an isomorphic alternation both generations have mostly, but not always, similar temperature responses. Photoperiodic responses may modify the temperature responses and should consequently always be taken into account.

It is, moreover, necessary to make an estimate of the difference between the experimental temperature limits and the corresponding mean monthly temperatures of the sea surface in order to be able to "translate" an experimental temperature limit to a boundary approaching a surface isotherm. These estimates can be made in the following way.

A "southern lethal summer temperature" is considered to correspond with the maximum August temperature of the uppermost surface water, which is taken, in its turn, to correspond approximately with a three centigrades lower mean August tempera- 
ture (cf. Earle, 1969). It should be realized, however, that this difference can be greater in protected lagoons.

A "southern growth and/or reproduction winter temperature" corresponds with the mean maximum February temperature (for the correct temperature has to be provided each year); which is taken, in its turn, to correspond with a two centigrades lower mean February temperature for temperatures above $10^{\circ} \mathrm{C}$, and with a one centigrade lower mean February temperature below $10^{\circ} \mathrm{C}$.

A "northern lethal winter temperature" is considered to correspond with the minimum February temperature of the surface layer. This corresponds with a one centigrade higher mean February temperature (two centigrades for temperatures above $10^{\circ} \mathrm{C}$ ).

A "northern growth and/or reproduction temperature" is considered to correspond with a mean minimum August temperature of surface water, and this with a two centigrades higher mean August temperature.

The present study presents evidence for the validity of the following phytogeographic distribution groups: the amphiatlantic tropical-to-warm temperate group with a northeastern extension (group 1, Fig. 1); the amphiatlantic tropical-to-temperate group (group 3, Fig. 2); the amphiatlantic temperate group of the Cladophora rupestris type (group 4, Fig. 3) and a type with features of the Cl. rupestris as well as the Cl. albida type (Fig. 3) (groups 4 and 5); the N.E. American temperate group (group 8, Fig. 4); the Japanese equivalent of the American temperate group (group 8); and the Arctic group (group 10, Fig. 4).

Table 1 lists the species and corresponding distribution groups for which the evidence is reviewed in the present paper.

Distribution data from the following publications were used for the construction of the distribution maps: Abbott \& Hollenberg (1976); Adey (1973); Adey et al. (1976); Ardré (1970, 1971); Baardseth (1941); Boudouresque \& Perret (1977); Brauner (1975); Breeman (1979); Chamberlain (1965); Chapman (1969); Chiang (1972, 1973); Chihara \& Yoshizaki (1970); Christensen \& Thomsen (1974); Dawes (1974); Dawson (1946); Day (1969); De May et al. (1977); De Sève et al. (1979); Diannelidis et al. (1977); Dixon \& Irvine (1977); Edelstein (1964); Edelstein et al. (1969, 1970); Edelstein \& McLachlan (1966, 1968); Edwards (1970a, 1979); Earle (1969); Feldmann (1942, 1954); FeldmannMazoyer (1940); Funahashi (1966, 1967, 1974); Funk (1955); Furnari et al. (1977); Furnari \& Scammacca (1973); Giaccone (1969, 1978); Giaccone \& Longo (1976); Hamel (1930); Hamel (1931-39); Haritonidis \& Tsekos (1974); Den Hartog (1959); Hawkes et al. (1978); Hirose \& Kajimura (1973); van den Hoek \& Donze (1967); Humm (1979); Jaasund (1965); John et al. (1977); Jonsson (1912); Juett et al. (1976); Kapraun (1977); Knaggs (1967); Konno (1973); Kornmann \& Sahling (1977); Kühnemann (1972); Lawson (1966); Lawson et al. (1975); Lawson \& John (1977); Lee (1980); Lee \& Kim (1977); Lee \& Lee (1976); Lindauer et al. (1961); Lipkin (1972); Levring (1960, 1974); Makienko (1975); Mathieson (1979); Moura Baptista (1977); Munda (1977, 1978, 1980); Nakaniwa (1975); Newton (1931); Nizamuddin et al. (1979); Ogawa \& Machida (1976); Oliveira Filho (1977); Orris \& Taylor (1973); Pankow (1971); Papenfuß (1964); Pedersen (1976); Perez-Cirera (1975); Pielou (unpublished list of distribution records along American coasts); Price et al. (1978); Rhodes (1970); Rueness (1977); Santelices (1980); Scagel (1957); Sčapova \& Vozžinskaja (1960); Schmidt (1931); Schneider (1976); Schneider et al. (1979); Searles \& 


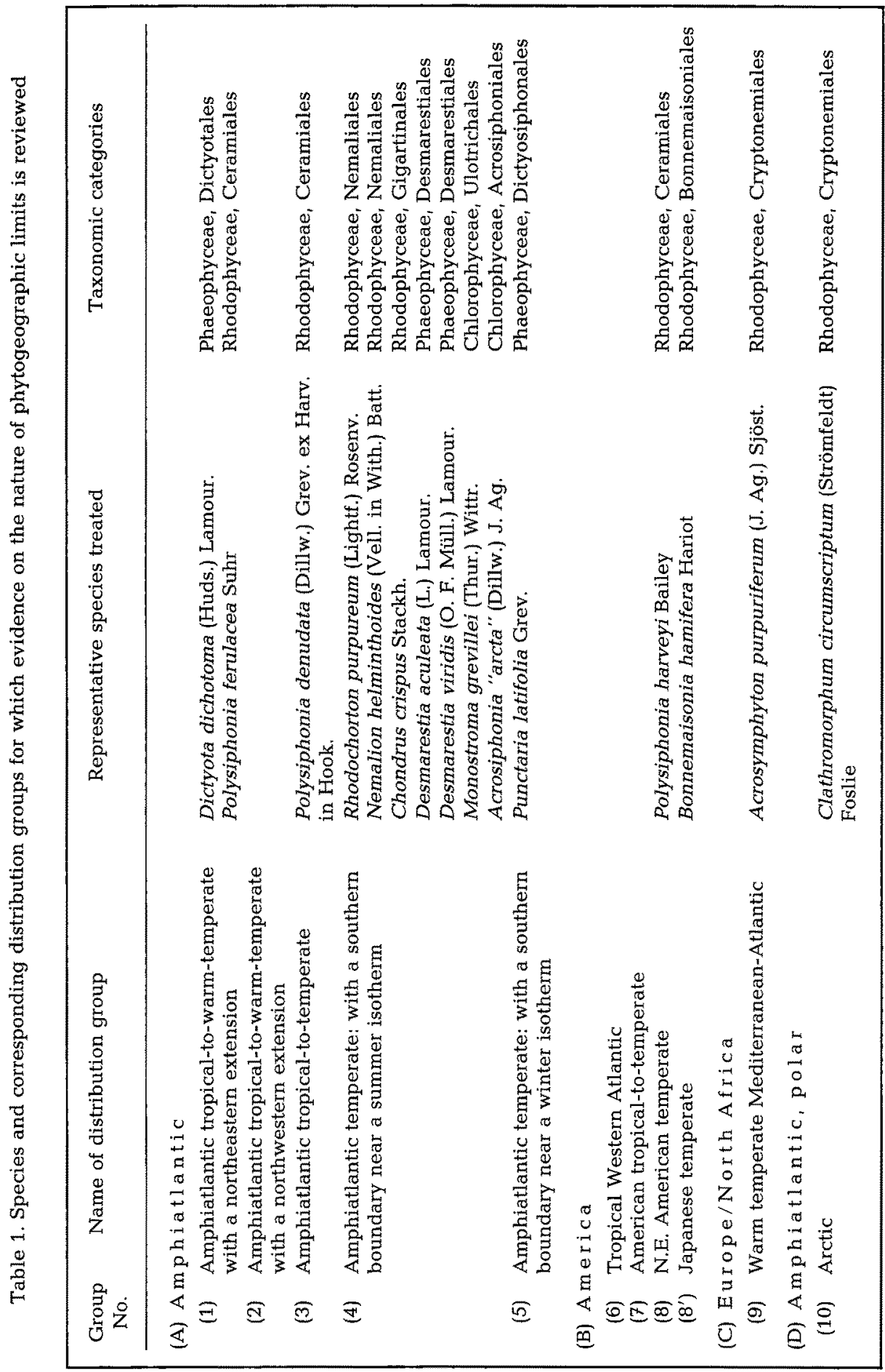


Schneider (1978); Sears (1971); Setchell \& Gardner (1919-20, 1925); South (1976); South \& Hooper (1980); Stephenson \& Stephenson (1972); Tanaka \& Itono (1972); Taylor (1945, 1957, 1960); Tokida (1954); Tsekos \& Haritonidis (1977); Tsuda \& Wray (1977); Velasquez et al. (1975); Velasquez \& Lewmanomont (1975); Vozžinskaja (1964, 1965); Wilce (1959); Womersley $(1965,1967)$; Womersley \& Bailey (1970); Zaneveld (1972, 1976); Zimmermann \& Livingston (1976); Zinova (1953, 1955, 1967).

The amphiatlantic tropical-to-warm temperate group with a northeastern extension

\section{Dictyota dichotoma}

Life history

Dictyota dichotoma has an isomorphic alternation between a tetrasporophyte generation and a dioecious gametophyte generation with oogamy. Dictyota dichotoma grows rapidly, and several generations may follow each other in the cours of one year. Sporophytes and gametophytes are present at the same time and not connected in a seasonal sequence. The production of eggs is claimed to have a lunar periodicity (Müller, 1962; Vielhaben, 1963). The influence of temperature on reproduction has not been investigated.

Near its northern boundary in N.E. America (in N. Carolina) D. dichotoma disappears from January through March. It appears to survive the winter in the form of small decumbent germlings which resume growth by the formation of erect blades after transfer to higher temperatures (Richardson, 1979). These germlings remain "dormant" under "winter conditions" $\left(12^{\circ} \mathrm{C}\right)$ in culture, and resume growth (by formation of blades) after transfer to $24^{\circ} \mathrm{C}$ in culture.

At Beaufort (N. Carolina) inshore populations of $D$. dichotoma must be able to survive intermittently winter temperatures as low as $3{ }^{\circ} \mathrm{C}$ (Brauner, 1975). In Virginia this lowest temperature may even be $2{ }^{\circ} \mathrm{C}$ (Humm, 1979). This suggests a lethal winter temperature near $2^{\circ} \mathrm{C}$. In short term experiments $(12 \mathrm{~h}$ exposures) Dictyota dichotoma from Roscoff (Brittany, W. France) survived $3{ }^{\circ} \mathrm{C}$, but not $-2^{\circ} \mathrm{C}$ (Biebl, 1959). However, in the same type of experiments conducted with material from Puerto Rico, $D$. dichotoma survived $5{ }^{\circ} \mathrm{C}$, but not $3^{\circ} \mathrm{C}$ (Biebl, 1962). This indicates that $D$. dichotoma embraces a number of temperature ecotypes. There are comparable differences in the highest temperatures tolerated: plants from Roscoff survived $27^{\circ} \mathrm{C}$, but not $30^{\circ} \mathrm{C}$; and plants from Puerto Rico survived $32{ }^{\circ} \mathrm{C}$, but not $35^{\circ} \mathrm{C}$.

At $12^{\circ} \mathrm{C}$ Dictyota germlings did not grow (Richardson, 1979). Apparently the minimum temperature allowing growth must be higher than $12^{\circ} \mathrm{C}$.

\section{Geographic distribution in the North Atlantic Ocean}

The northern boundary of $D$. dichotoma in N.E. America approximates the $2{ }^{\circ} \mathrm{C}$ February isotherm, which limit can be explained as a "northern lethal boundary", approximately corresponding with a minimum February temperature of $1{ }^{\circ} \mathrm{C}$.

The northern boundary in Europe approximates the $13^{\circ} \mathrm{C}$ summer isotherm, which limit can be explained as a "northern growth and reproduction boundary". This would 


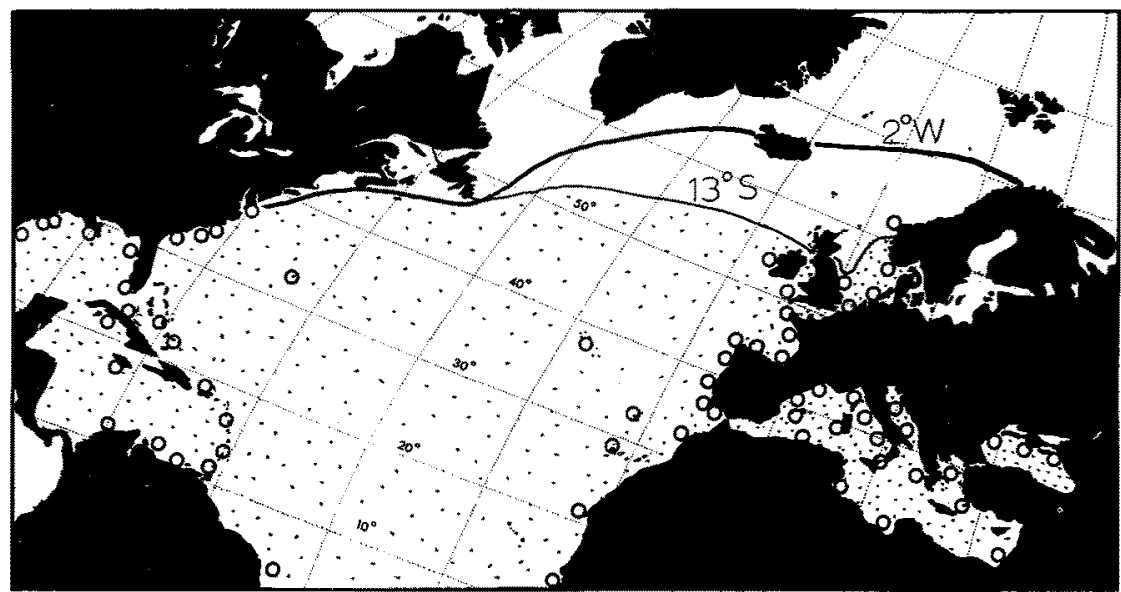

Fig. 5. Distribution of Dictyota dichotoma in the North Atlantic Ocean $(0) .2^{\circ} \mathrm{W}=2{ }^{\circ} \mathrm{C}$ winter (February) isotherm. $13^{\circ} \mathrm{S}=13^{\circ} \mathrm{C}$ summer (August) isotherm

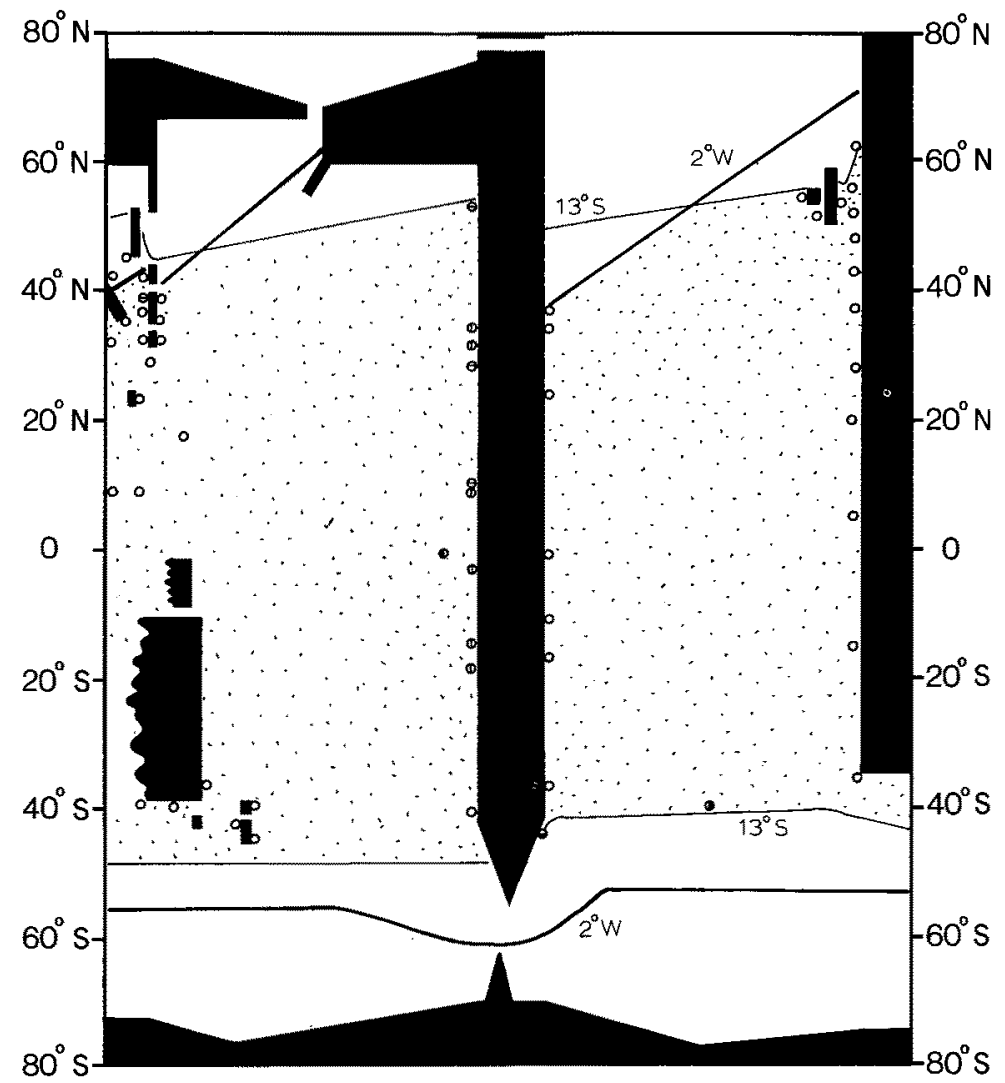

Fig. 6. Distribution of Dictyota dichotoma in the Pacific Ocean (left part in diagram) and Atlantic Ocean (right part in diagram) (O). In addition, the distributions are given of several entities which are difficult to differentiate from the form range of D. dichotoma. Dictyota flabellata (Coll.) S. \& G.

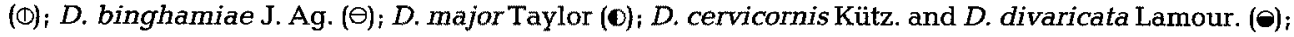
D. liturata J. Ag. (o). The southern and northern boundaries are, at the same time, boundaries of the 
correspond with a minimum temperature of $12{ }^{\circ} \mathrm{C}$ (the mean minimum August temperature) allowing growth and reproduction. According to the above experiments this temperature should be higher than $12^{\circ} \mathrm{C}$ (Fig. 5).

\section{Geographic distribution in the Pacific and Atlantic Oceans}

In Fig. 6, records of several other Dictyota species have been indicated. These species are difficult to differentiate from the form range of Dictyota dichotoma. Apparently, investigators of W. American material tended to attribute their material to species described for N.W. America.

The distribution of this complex of entities (in the majority of cases identified as $D$. dichotoma), can be explained by the same boundaries as those of $D$. dichotoma in the N. Atlantic Ocean.

On the east sides of both oceans "northern growth and reproduction boundaries" ( the $13^{\circ} \mathrm{C}$ summer isotherm) limit $D$. dichotoma to the north, and on the west sides "northern lethal boundaries" ( the $2{ }^{\circ} \mathrm{C}$ winter isotherm) limit $D$. dichotoma to the north. However, near Japan the northernmost records correspond with a lower temperature $\left(-1{ }^{\circ} \mathrm{C}\right)$.

In the southern hemisphere the southern boundary follows entirely a "southern growth and reproduction boundary" ( the $13^{\circ} \mathrm{C}$ summer isotherm). The "southern lethal boundary" (the $2{ }^{\circ} \mathrm{C}$ winter isotherm) is far more to the south than the actual southern boundary.

Dictyota dichotoma has the same type of distribution in the Atlantic and Pacific Oceans as Centroceras clavulatum (van den Hoek, 1982).

\section{Polysiphonia ferulacea \\ Life history}

$P$. ferulacea has an isomorphic alternation between gametophytic and tetrasporophytic phases (Polysiphonia type).

Isolates from Wrightsville Beach, North Carolina, grew well at 15,20 and $25^{\circ} \mathrm{C}$ and poorly or not at all at $10^{\circ} \mathrm{C}$ and $30^{\circ} \mathrm{C}$. Tetrasporangia were formed at $15,20,25$ and $30^{\circ} \mathrm{C}$; mature gonimocarps at 20 and $25^{\circ} \mathrm{C}$ (Kapraun, 1978a). In nature (at Wrightsville Beach), gonimocarps were found at temperatures from $18^{\circ}-28^{\circ} \mathrm{C}$ (Kapraun, 1980).

\section{Geographic distribution in the North Atlantic Ocean}

The northern boundary of Polysiphonia ferulacea in N.E. America approximates the $10^{\circ} \mathrm{C}$ February isotherm (Fig. 7). This can be explained as a "northern lethal boundary", corresponding with a lethal temperature of $8^{\circ} \mathrm{C}$. Poor growth occurred at $10^{\circ} \mathrm{C}$ in the above experiments; lower temperatures were not tested. In short term experiments $(12 \mathrm{~h}$ exposure) $P$. ferulacea from Puerto Rico survived $3{ }^{\circ} \mathrm{C}$ but not $1{ }^{\circ} \mathrm{C}$; short term experiments are apparently less relevant in the present context than long term experiments (Biebl, 1962).

The northern boundary in Europe approximates the $20^{\circ} \mathrm{C}$ summer isotherm. This can be explained as a "northern reproduction boundary", corresponding with a minimum temperature of $18^{\circ} \mathrm{C}$ allowing formation of mature gonimocarps. This distribu- 
tion pattern of Polysiphonia ferulacea in the North Atlantic Ocean is very similar to that of Centroceras clavulatum (van den Hoek, 1982).

No records of $P$. ferulacea are known from the Mediterranean and N.W. Africa, although the species could be expected there. One possible reason is the partly confused taxonomy of Polysiphonia which is in need of revision for large areas.

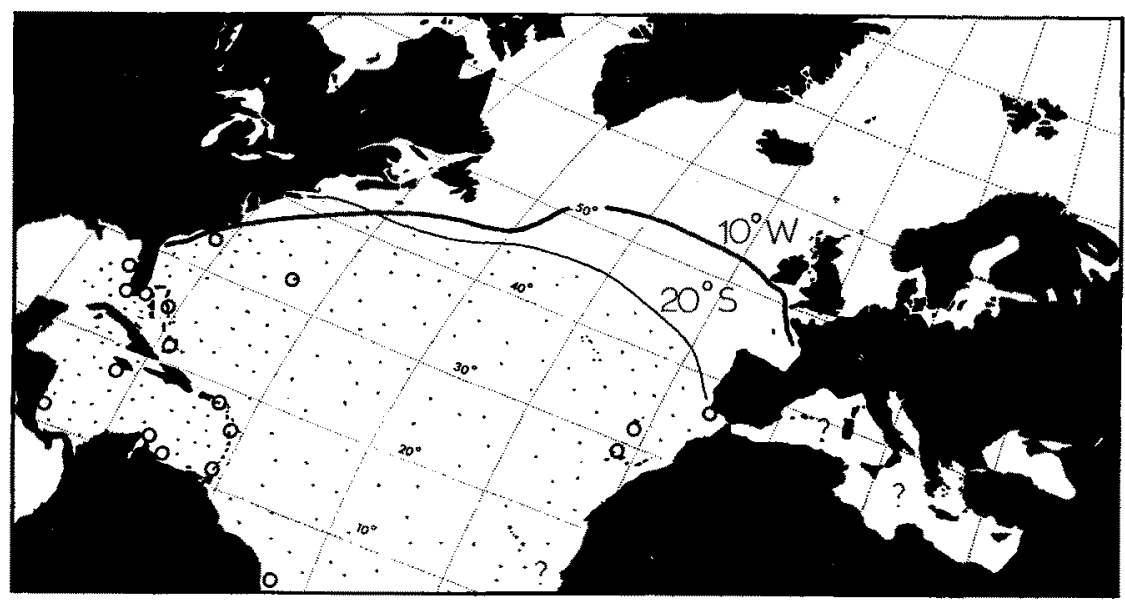

Fig. 7. Distribution of Polysiphonia ferulacea in the North Atlantic Ocean

The absence along the northern coast of the Gulf of Mexico can be explained by winter temperatures being intermittently as low as $4{ }^{\circ} \mathrm{C}$ in inshore water.

The amphiatlantic tropical-to-temperate group

\section{Polysiphonia denudata}

\section{Life history}

$P$. denudata has an isomorphic alternation between gametophytic and tetrasporophytic phases (Polysiphonia type).

Isolates from Wrightsville Beach, North Carolina, grew well at 15,20 and $25^{\circ} \mathrm{C}$, and slowly at $10^{\circ} \mathrm{C}$ and $30^{\circ} \mathrm{C}$. Tetrasporangia were formed at $15,20,25$ and $30^{\circ} \mathrm{C}$; antheridia were formed at $10-30^{\circ} \mathrm{C}$, carpogonia at $15-30^{\circ} \mathrm{C}$ (Kapraun, 1978). Mature gonimocarps were obtained in cultures at $20-23^{\circ} \mathrm{C}$. In nature, at Wrightsville Beach, gonimocarps occurred at temperatures from $11-28^{\circ} \mathrm{C}$.

Isolates from Port Aransas, Texas, had slightly different temperature responses (Edwards, 1970b). The isolates grew well at 19, 23, 26.5, and $30^{\circ} \mathrm{C}$, poorly at $14.5^{\circ} \mathrm{C}$, and not at all at $10.5^{\circ} \mathrm{C}$. Mature gonimocarps were formed at $23^{\circ} \mathrm{C}$ and $26.5^{\circ} \mathrm{C}$; tetrasporangia at $19,23,26.5$, and $30^{\circ} \mathrm{C}$. These isolates are better adapted to the higher maximum temperatures at Port Aransas than at Wrightsville Beach. Apparently $P$. denudata comprises various temperature ecotypes. 
Geographic distribution in the North Atlantic Ocean

The northern boundary of $P$. denudata approximates the $16^{\circ} \mathrm{C}$ August isotherm on both sides of the Ocean (Fig. 8). This limit can be explained as a "northern reproduction boundary", corresponding with a minimum temperature of $15^{\circ} \mathrm{C}$ necessary for the production of one of the reproductive stages, in this case probably the production of tetraspores by the tetrasporophyte. This on the assumption that the northern populations have the same temperature requirements as the Wrightsville Beach isolates.

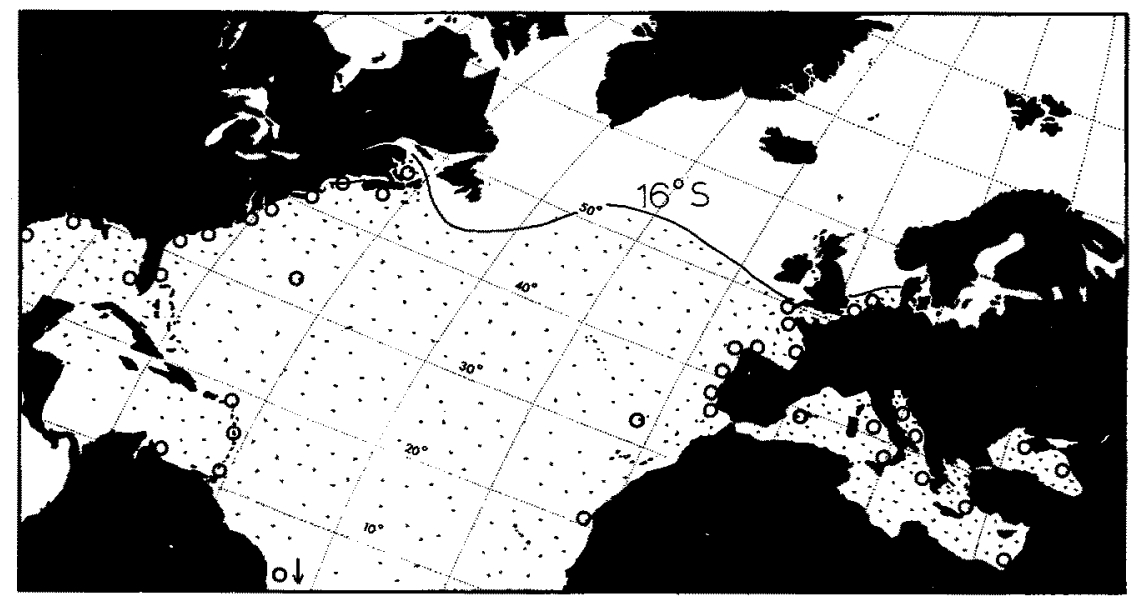

Fig. 8. Distribution of Polysiphonia denudata in the North Atlantic Ocean

At its northern point of occurrence in N.E. America $P$. denudata must be capable of surviving ice cover and temperatures as low as $-2{ }^{\circ} \mathrm{C}$ in winter. In the protected and shallow embayments where $P$. denudata occurs summer temperatures may rise above $20^{\circ} \mathrm{C}$ and thus cause optimal growth and reproduction.

Apparently the temperature requirements of $P$. denudata correspond to the wide annual temperature fluctuations (more than $20^{\circ} \mathrm{C}$ on one point) along the N.E. American coasts.

Polysiphonia denudata is quite characteristic for the "tropical-to-temperate distribution group" in being restricted, at its northern boundary, to shallow protected embayments. Other examples are Cladophora vagabunda, Cl. liniformis, Chondria dasyphylla, C. tenuissima, Spyridia filamentosa.

The species of the American tropical-to-temperate distribution group (group 7, Fig. 4) bridge a comparably wide temperature span and are also mostly restricted to shallow protected embayments. Examples are Gracilaria tikvahiae, Grinnellia americana, Solieria tenera, Lomentaria baileyana (van den Hoek, 1982).

The amphiatlantic temperate group with a southern boundary near a winter isotherm

The species of the Cladophora rupestris type are characterized by having summer isotherms, corresponding with lethal summer temperatures, as southern boundaries 
(Fig. 3). Rhodochorton purpureum is an example which will be discussed more fully below. UIvaria obscura probably also belongs to this distribution group.

A close examination of the distribution and the temperature requirements of a number of species in this distribution group has revealed that the majority of species have a composite southern boundary. Along E. Atlantic shores these boundaries follow winter isotherms (corresponding with maximum winter temperatures allowing reproduction) and along American shores summer isotherms (corresponding with lethal summer temperatures). Nemalion helminthoides, Chondrus crispus, Desmarestia viridis, D. aculeata, Monostroma grevillei and probably also Acrosiphonia arcta are examples with such composite southern boundaries in the North Atlantic Ocean.

\section{Rhodochorton purpureum}

\section{Life history}

Rhodochorton purpureum is a small filamentous rhodophyte which forms dense velvety turfs on shaded rocks in the eulittoral and in the sublittoral zones. In the peculiar life history of this species the carpogonia on dwarf female gametophytes are fertilized by spermatia produced by dwarf male gametophytes. The fertilized carpogonia develop into small gonimoblasts which develop directly into tetrasporophytes which in the end overgrow completely the dwarf female gametophyte to which they grow attached. The gametophytes are mostly dioecious, but there are also monoecious strains (West, 1969, 1970; Stegenga, 1978; Ohta \& Kurogi, 1979).

The formation of tetrasporangia is influenced by photoperiod as only under short daylength conditions are tetrasporangia formed. A light break during the long dark period has no effect, so that the response cannot be considered a true photoperiodic response (in the sense of Vince-Prue, 1975). As in Scytosiphon lomentaria (Lüning, 1981a) there are different latitudinal daylength-temperature ecotypes (West, 1972; Stegenga, 1978; Hoeksema \& Breeman, in prep.). In N.W. America, two northern strains had tetrasporangia formed in culture at daylengths of 12 hours or less and temperatures of $5^{\circ}$ and $10^{\circ} \mathrm{C}$ (not at $15^{\circ}$ and $20^{\circ} \mathrm{C}$ ) (Fig. 9a, b).

One southern strain in N.W. America (Fig. 9C) had its tetrasporangia formed at daylengths of 10 hours or less, and at temperatures of $10^{\circ}$ and $15^{\circ} \mathrm{C}$ (not at $5^{\circ}$ and $20^{\circ} \mathrm{C}$ ).

One strain from Chile (Fig. 9d) had its tetrasporangia formed at 5, 10, and $15^{\circ} \mathrm{C}$, and not at $20^{\circ} \mathrm{C}$. Only at $15^{\circ} \mathrm{C}$, did daylengths of 10 hours or less clearly promote formation of tetrasporangia (not at $5{ }^{\circ} \mathrm{C}$ and $10^{\circ} \mathrm{C}$ ). Apparently the response to daylength restricting tetrasporulation to the winter months, only operates under the prevalent temperature conditions along the Chilean coasts.

Two strains from the Netherlands (Fig. 9e, f) formed tetrasporangia at daylengths of less than 12 hours, and at temperatures of $4,8,12$ and $16{ }^{\circ} \mathrm{C}$ (not at $18{ }^{\circ} \mathrm{C}$ ). These strains have been isolated from water with mean annual temperature fluctuation of c. $3^{\circ}-19^{\circ} \mathrm{C}$. The maturation of the gametophytes appeared not to be influenced by photoperiod.

The average monthly temperatures at the points where the five strains were collected, probably never had values blocking tetrasporogenesis so that, there, photoperiod is the primary factor restricting tetrasporogenesis to the winter half year. However, all strains can be expected to become intermittently subjected to extreme summer temperatures that are several centigrades higher than the mean monthly August temper- 


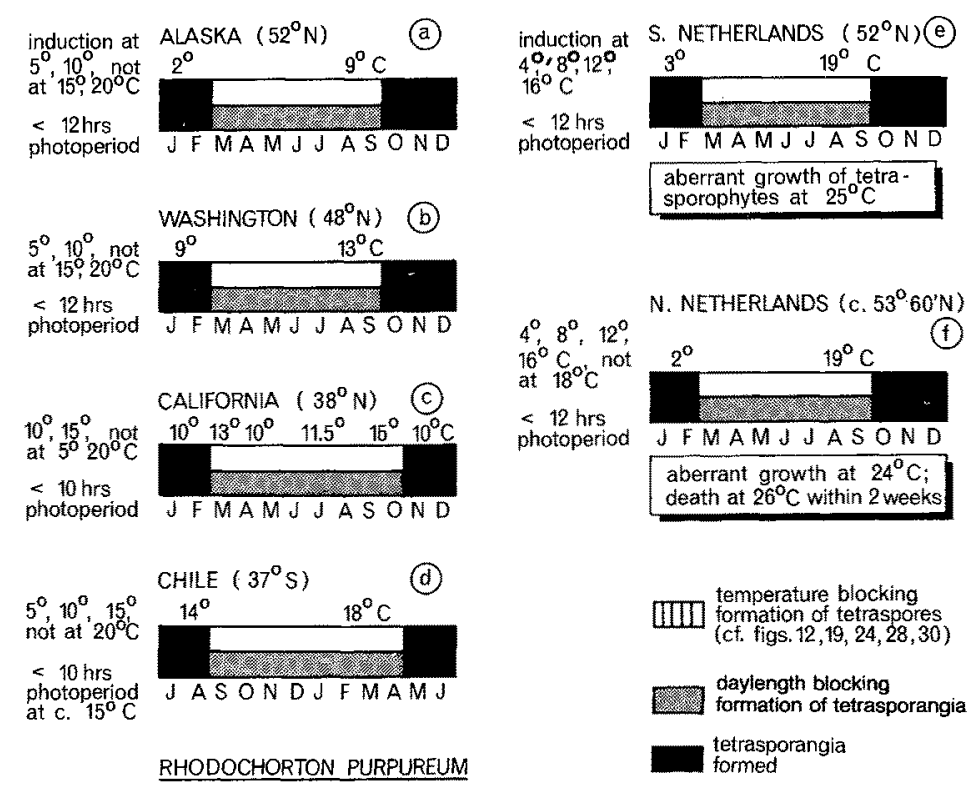

Fig. 9. Rhodochorton purpureum. Conditions (temperature, daylength) influencing tetrasporogenesis in the course of the year. $(a, b, c)$ Three N.W. American strains and (d) a S.W. American strain (based on West, 1972); (e) material from the S. Netherlands (based on Stegenga, 1978); (f) material from the N. Netherlands (Hoeksema \& Breeman, 1982, in prep.)

ature, and in that case tetrasporogenesis can be expected to be blocked by too high temperatures in autumn. Vegetative growth appeared to be clearly slower under short day than under long day conditions. No vegetative growth was observed in $W$. American strains at $20^{\circ} \mathrm{C}$ (West, 1969), whereas a Dutch strain grew well at temperatures from $8^{\circ}$ through $20^{\circ} \mathrm{C}$, but hardly above $20^{\circ} \mathrm{C}$. At $24^{\circ} \mathrm{C}$ and $25^{\circ} \mathrm{C}$ the Dutch strains showed abnormal growth; and at $26^{\circ} \mathrm{C}$ one strain was repeatedly observed to die within two weeks (Hoeksema \& Breeman, 1982, in prep.).

\section{Phytogeographic boundaries in the North Atlantic Ocean}

The "southern reproduction boundary" of Rhodochorton purpureum must be situated near a point where, during a period of 1 to 2 months in each winter, temperature drops below c. $17^{\circ} \mathrm{C}$ in order to allow tetrasporogenesis. This on the assumption that the southernmost strains in Europe have the same temperature requirements as the investigated Dutch strains. This would correspond with a mean maximum February temperature of $17^{\circ} \mathrm{C}$ of the upper layer of inshore water, and roughly with a mean February temperature of $15^{\circ} \mathrm{C}$. The $15^{\circ} \mathrm{C}$ winter isotherm, however, is more to the south than the actual southern boundary in the North Atlantic.

The "southern lethal boundary" of $R$. purpureum must be situated near a point where, during a period of c. 2 weeks temperature of inshore surface water exceeds $24^{\circ} \mathrm{C}$ during an excessively warm summer. This would correspond with a maximum August temperature of $24^{\circ} \mathrm{C}$ and a mean August temperature of $21^{\circ} \mathrm{C}$. The actual southern 


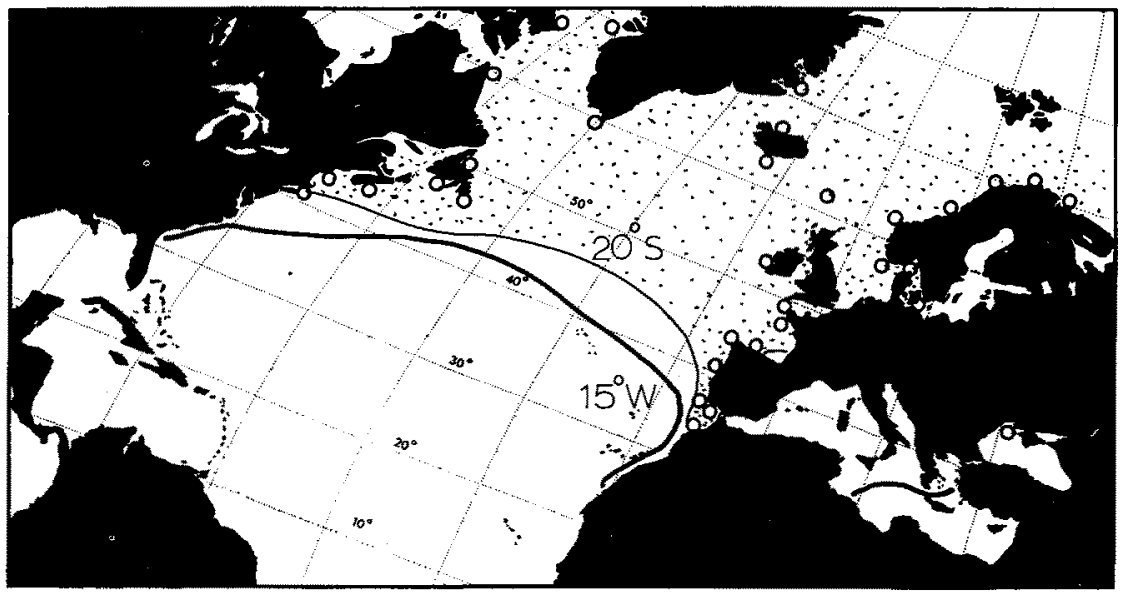

Fig. 10. Distribution of Rhodochorton purpureum in the North Atlantic Ocean. $20^{\circ} \mathrm{S}=20^{\circ} \mathrm{C}$ summer isotherm; $15^{\circ} \mathrm{W}=15^{\circ} \mathrm{C}$ winter isotherm. Records from the Mediterranean are uncertain

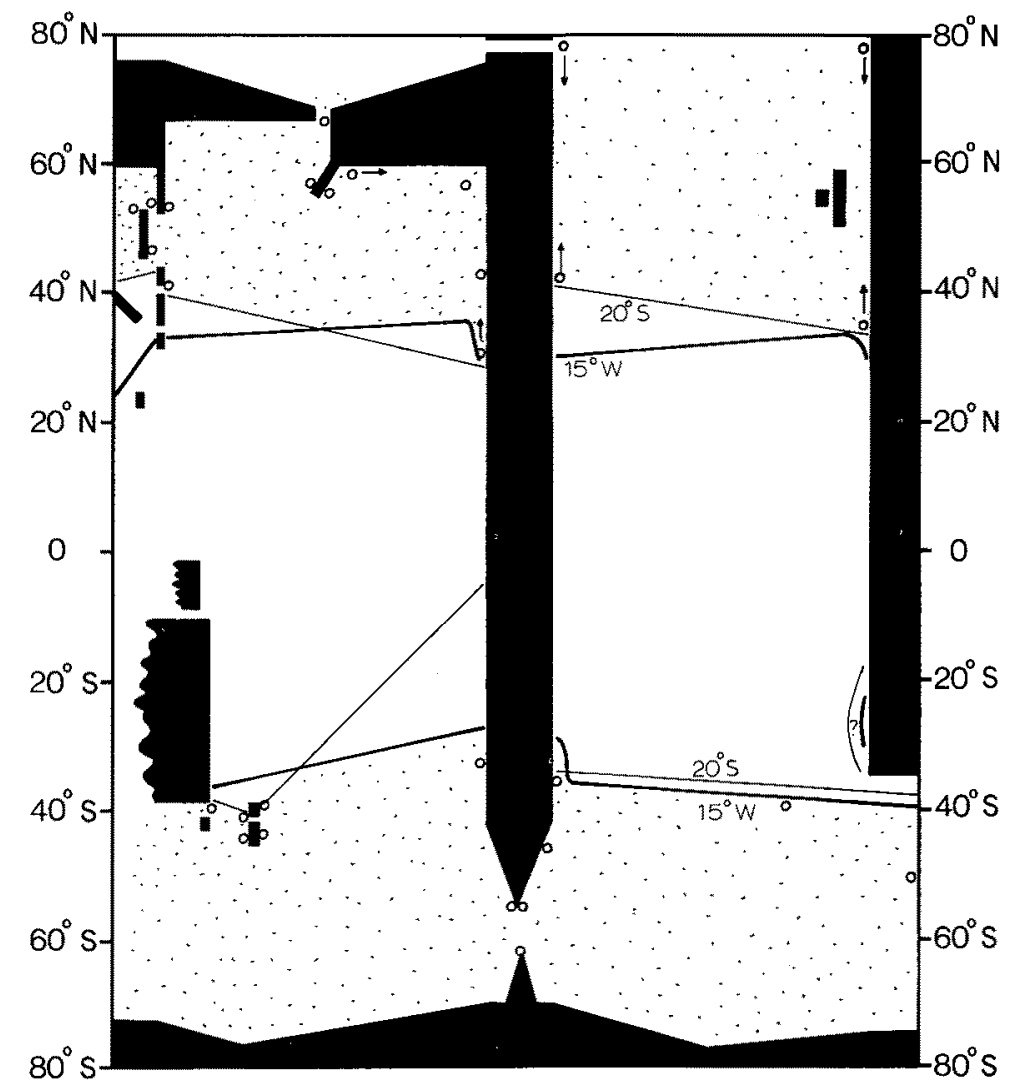

Fig. 11. Distribution of Rhodochorton purpureum in the Pacific Ocean (left part of diagram) and Atlantic Ocean (right part of diagram) 
boundary is near the $20^{\circ} \mathrm{C}$ August isotherm (Fig. 10). The rare records of $R$. purpureum from the Mediterranean should be checked to exclude confusion with other species.

The intertidal shade populations are exposed at low tide, to still higher temperatures than $25^{\circ} \mathrm{C}$ at the southern geographic boundary.

In the north, $R$. purpureum extends into the Arctic Region, where it must cope with extremely low temperatures during the Arctic winter. For instance, at Spitsbergen the mean monthly temperature of the seawater is $-1.1^{\circ} \mathrm{C}$ in February and $1.3^{\circ} \mathrm{C}$ in August; and the mean monthly air temperature is $-16.1^{\circ} \mathrm{C}$ (with a minimum of $-42^{\circ} \mathrm{C}$ ) in January and $5.6^{\circ} \mathrm{C}$ (with a maximum of $13^{\circ} \mathrm{C}$ ) in July (Biebl, 1962). In summer, the species must be able to grow and reproduce at water temperatures between 0 and $5{ }^{\circ} \mathrm{C}$, and this at comparatively long, short photoperiods. Only if $R$. purpureum has daylengthtemperature ecotypes adapted to Arctic daylength and temperature conditions, such as Scytosiphon lomentaria has, is it imaginable that this species can flourish in Arctic regions. The influence of Arctic conditions on $R$. purpureum's life history has not yet been experimentally investigated.

\section{Distribution in the Pacific and Atlantic Oceans}

The available distribution data (Fig. 11) suggest that $R$. purpureum in the North and South Atlantic Ocean and the North Pacific Ocean is limited towards the equator by $20^{\circ} \mathrm{C}$ summer isotherms (August isotherm in the northern hemisphere; February isotherm in the southern hemisphere). However, in the South Pacific Ocean the species seems to be bounded towards the equator by the $15^{\circ} \mathrm{C}$ winter isotherm along the American coast, and by the $20^{\circ} \mathrm{C}$ summer isotherm along the New Zealand and Australian coasts. The species occurs in Antarctica, although it is possibly restricted to parts projecting from the mainland. This global distribution pattern suggests that $R$. purpureum has the same genotypic range of temperature and daylength adaptation in the northern and the southern hemispheres.

\section{Nemalion helminthoides}

\section{Life history}

The slippery, worm-like gametophytes of Nemalion appear in summer on waveexposed rocks in most of its distribution area. The life history comprises, in addition, a strongly heteromorphic tetrasporophyte which is composed of irregularly branched filaments. The multiaxial gametophyte arises from a similar filamentous stage. The species apparently hibernates in the form of these filamentous stages (Fries, 1967, 1969; Martin, 1967; Umezaki, 1967*), which can be termed tetrasporophytic and gametophytic microthalli (van den Hoek et al., 1972). Both tetrasporophytic and gametophytic microthalli appear to reproduce vegetatively by monospores under a wide range of conditions.

In two recent studies (Chen et al., 1978; Masuda \& Umezaki, 1977) the temperature and daylength conditions influencing the life history have been studied; the results of both studies are in agreement, and their results will be summarized here.

Tetrasporogenesis is induced by short day conditions (photoperiods $\leqslant 12 \mathrm{hrs}$ ) and

\footnotetext{
- N. vermiculare Suringar is here considered to belong to the form range of $N$. helminthoides.
} 
relatively high temperatures $\left(\geqslant 10^{\circ} \mathrm{C} ; \leqslant 18^{\circ} \mathrm{C}\right)$; tetrasporangia are formed in 1 to 2 weeks. Tetrasporangia are not formed under 5 and $22^{\circ} \mathrm{C}$ short day conditions.

Macrothalli are initiated from gametophytic microthalli only under long day conditions (photoperiods $>12 \mathrm{hrs}$ ) and at temperatures between about 12 and $22^{\circ} \mathrm{C}$. Macrothalli need about 4 months to mature and to form carpospores.

In axenic cultures, microthalli show positive, though slow growth at $12{ }^{\circ} \mathrm{C}$, and maximum growth at $20^{\circ} \mathrm{C}$. Temperatures between 26 and $27^{\circ} \mathrm{C}$ are lethal (Fries, 1966).

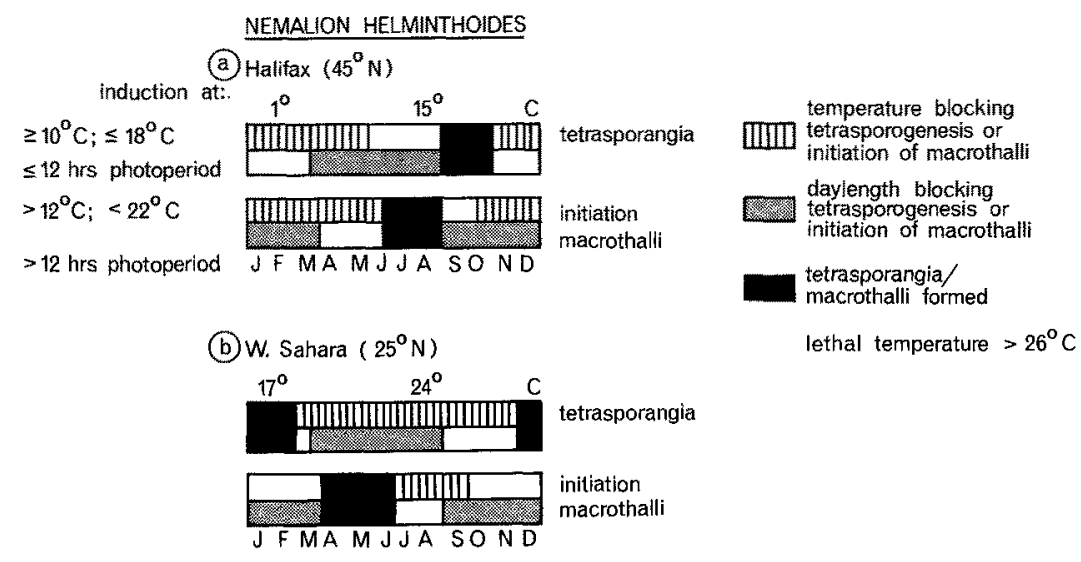

Fig. 12. Nemalion helminthoides. Model of the seasonal reproductive cycle in Halifax, Nova Scotia (near northern boundary) and in the W. Sahara (southern boundary), by applying culture results to the conditions in both regions

When one applies the above culture data to the seasonal conditions at Halifax, Nova Scotia $\left(45^{\circ} \mathrm{N}\right)$, a model of the seasonal sequence of the phases is obtained as pictured in Fig. 12a. The occurrence of tetrasporangia in nature is unknown, but the gametophytes appear indeed in midsummer, to disappear gradually in autumn (South \& Hooper, 1980). Where spring temperatures are higher the gametophyte appears earlier.

At the southernmost point of its geographic area, in the western Sahara $\left(25^{\circ} \mathrm{N}\right)$ the gametophyte can be expected to appear in spring (Fig. 12b).

\section{Geographic boundaries in the North Atlantic Ocean}

The "southern growth and reproduction boundary" of the gametophyte can be expected near a point where, in the period April through August (when daylengths are 12 hours or longer) temperature drops below $22^{\circ} \mathrm{C}$ for about $2-3$ months. This would approximately correspond with a June temperature of $21^{\circ} \mathrm{C} ;$ and this with an August temperature of c. $23^{\circ} \mathrm{C}$. As the species can survive in the form of microthalli, these conditions can be average conditions. Thus, the "southern growth and reproduction boundary" of the gametophyte can be expected near the $23{ }^{\circ} \mathrm{C}$ summer isotherm. In general, "southern growth and reproduction boundaries" approximate winter isotherms, because they represent the highest possible temperature allowing growth and reproduction of northern species. In N. helminthoides, however, the "southern growth and reproduction boundary" of the gametophyte is determined by a summer temperature, as short photoperiods ( $\leqslant 12 \mathrm{hrs}$ ) block growth in winter and restrict it to the summer. 
The "southern lethal boundary" can be expected near a point where the temperature rises above $27^{\circ} \mathrm{C}$. This would approximately correspond with a maximum August temperature of surface water of $27^{\circ} \mathrm{C}$, and this with a mean August temperature of about $24^{\circ} \mathrm{C}$. Thus, the "southern lethal boundary" can be expected near the $24{ }^{\circ} \mathrm{C}$ summer isotherm, and to coincide approximately with the "southern growth and reproduction boundary" of the gametophyte. Particularly in the Mediterranean, the actual southern boundary is near the $25^{\circ} \mathrm{C}$ summer isotherm (Fig. 13).

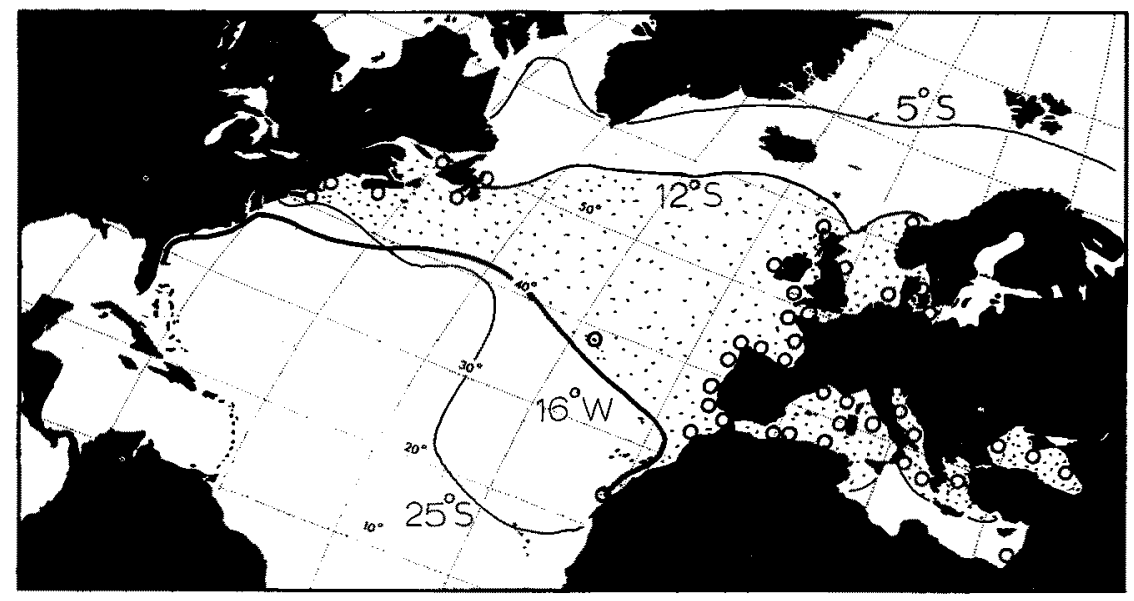

Fig. 13. Nemalion helminthoides. Distribution in the North Atlantic Ocean

The "southern reproduction boundary" for the formation of tetraspores by the tetrasporophyte and consequently of the formation of gametophytes, can be expected near a point where, in the period September through half March, temperature is $18{ }^{\circ} \mathrm{C}$ or lower for about 2 weeks in each year. This would correspond with a mean February temperature of c. $16^{\circ} \mathrm{C}$. This corresponds indeed with the southern boundary.

The "northern reproduction boundary" for the formation of tetraspores and consequently of gametophytes can be expected near a point where, in the period September through half March, temperature is each year above $10^{\circ} \mathrm{C}$ for about two weeks. This corresponds approximately with a mean September temperature and August temperature of $11^{\circ} \mathrm{C}$.

The "northern growth and reproduction boundary" of the gametophyte can be expected near a point where in the period April through August (with photoperiods $>12$ hours) temperature is above $12^{\circ} \mathrm{C}$ for at least two months in an average summer (for the species can survive cold summers as self-reproducing microthallus). This would approximately correspond with a mean August temperature of $12^{\circ} \mathrm{C}$. The actual northern boundary follows indeed closely the $12^{\circ} \mathrm{C}$ summer isotherm.

The "northern lethal boundary" of $N$. helminthoides has not been experimentally tested, but microthalli grow slowly at $5^{\circ} \mathrm{C}$, and must be able to survive frost during low tide at its northern boundary. This would position the "northern lethal boundary" north of the $0{ }^{\circ} \mathrm{C}$ winter isotherm. Possibly therefore the $5^{\circ} \mathrm{C}$ summer isotherm is the "northern 
growth boundary" of the microthalli. The capacity of the microthalli for independent vegetative reproduction by monospores makes it likely that Nemalion occurs to the north of the $12{ }^{\circ} \mathrm{C}$ summer isotherm in the form of hitherto unrecognized microthalli, much in the way as the tetrasporophytes of Bonnemaisonia hamifera has a much more northern extension than the gametophyte.

\section{Geographic distribution in the Atlantic and Pacific Oceans}

In the northern hemisphere Nemalion helminthoides is bounded on both sides of the Pacific and Atlantic Oceans by approximately the $12^{\circ} \mathrm{C}$ summer isotherm in the north and the $25^{\circ} \mathrm{C}$ summer isotherm and the $16^{\circ} \mathrm{C}$ winter isotherm in the south (Fig. 14).

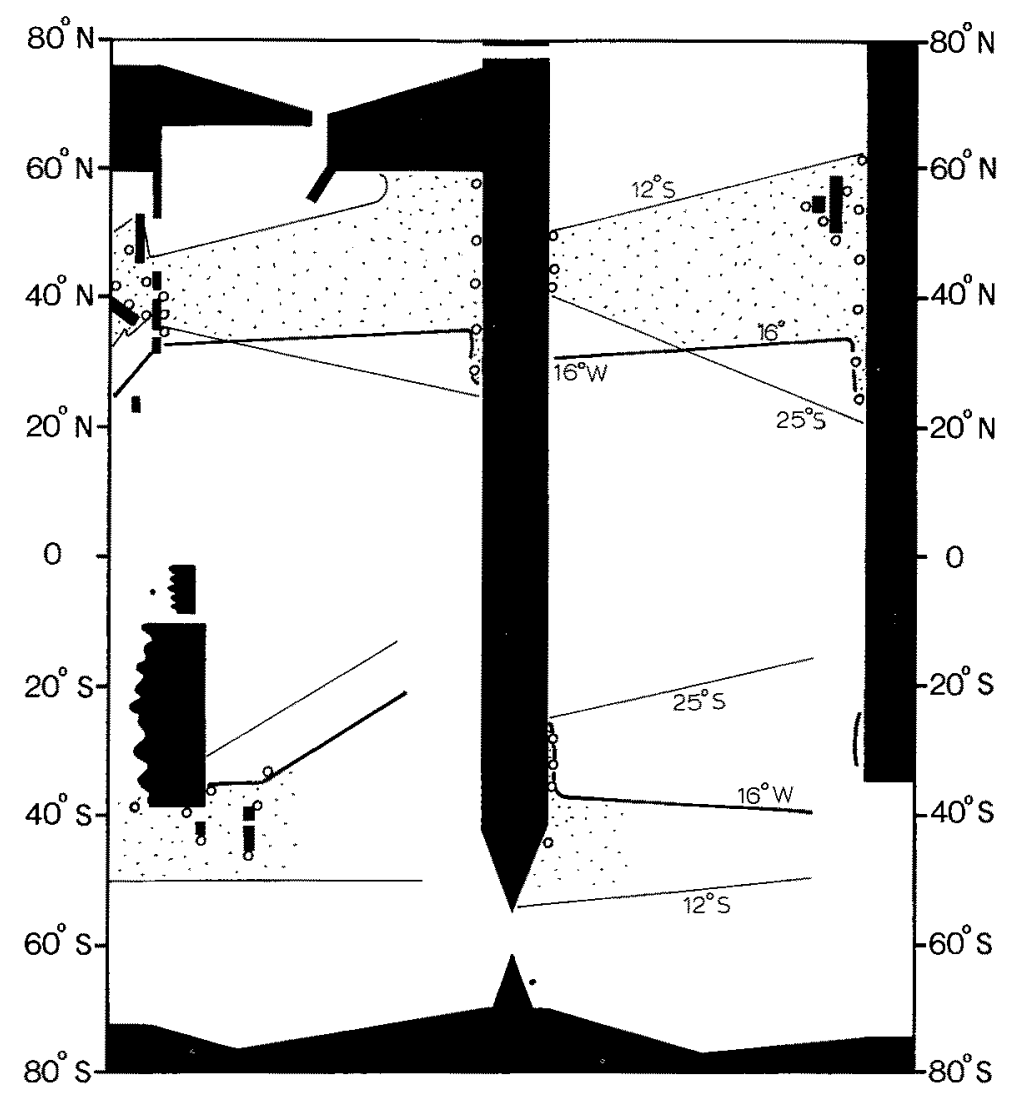

Fig. 14. Nemalion helminthoides. Distribution in the Pacific Ocean (left part of diagram) and Atlantic Ocean (right part of diagram)

In the southern hemisphere the species occurs on the western sides of both oceans and here their distribution accords with that in the northern hemisphere. I did not find records for the eastern Pacific and Atlantic coasts, nor for subantarctic islands, in the southern hemisphere. This is especially unexpected for the Chilean coasts, as these are directly connected, via Fuegia, with the coast of Argentina. In a personal communication, Dr. B. Santelices has confirmed the absence of records for Chilean coasts. 
The point should be stressed that only one type of environmental regulation, valid for Japanese and Nova Scotia material, can explain the distribution of $N$. helminthoides. Other widely distributed, amphiequatorial species, such as Scytosiphon lomentaria and Rhodochorton purpureum, have different latitudinal temperature-daylength ecotypes.

\section{Chondrus crispus}

\section{Life history}

Chondrus crispus has an alternation between isomorphic tetrasporophytes and gametophytes. Both phases consist of basal crusts from which fan-like erect fronds arise. The basal crusts do not have independent means of reproduction.

In cultures, carpospores and tetraspores germinated at temperatures from $5^{\circ} \mathrm{C}-20^{\circ} \mathrm{C}$, but not higher than $20^{\circ} \mathrm{C}$ (Chen \& McLachlan, 1972).

Growth was slow at $5^{\circ} \mathrm{C}$ and $25^{\circ} \mathrm{C}$, and maximal at $15^{\circ} \mathrm{C}$ and $20^{\circ} \mathrm{C}$ (Bird et al., 1978; Simpson \& Shacklock, 1979). At $30^{\circ} \mathrm{C}$ plants died within ten days (Simpson \& Shacklock, 1979).

Cultures grown from spores at $15^{\circ} \mathrm{C}$ and a 16 hours photoperiod needed about 8-10 months to attain a length of $5-8 \mathrm{~cm}$ and to become mature. Gametophytes matured only under long day conditions ( $16 \mathrm{~h}$ photoperiod, not $12 \mathrm{~h}$ ) and $15^{\circ} \mathrm{C}$. Tetrasporogenesis took place under long day and short day conditions, and temperatures of $15^{\circ} \mathrm{C}, 13^{\circ} \mathrm{C}$, and $5{ }^{\circ} \mathrm{C}$, but seemed to be promoted by transfer to short day conditions (10 and $8 \mathrm{~h}$ photoperiods). Mature plants continued the formation of reproductive cells for several months. After that, male plants and tetrasporophytes resumed growth; gametophytes were reduced to the basal crust which could give off new erect fronds. Basal crusts are in general important for the maintenance of populations in nature (Chen \& McLachlan, 1972).

In accordance with these culture results, gametophytes and sporophytes can be found throughout the year in subtidal populations on the coast of New Hampshire. Midlittoral populations show a summer interruption in the production of reproductive cells, probably as a result of adverse intertidal conditions (later maturation as a result of ice scouring, desiccation, higher temperatures). Adverse high temperatures were also found in the above culture results (no reproduction at $20^{\circ} \mathrm{C}$ ). Tetraspore production is also reduced in summer in subtidal populations, and is maximal in autumn. These field observations suggest that tetrasporogenesis is promoted by, but not restricted to, short daily photoperiods. In short: the reproduction of Chondrus crispus does not present a distinct seasonality (Tveter-Gallagher et al., 1980).

\section{Geographic boundaries in the North Atlantic Ocean}

The culture results indicate that the erect fronds must have a minimum length of about $5 \mathrm{~cm}$ before they can mature. This suggests that temperatures must have, during a period of several months, a value allowing sufficient vegetative growth.

The "southern growth boundary" can consequently be expected near a point where temperature drops in winter below $25^{\circ} \mathrm{C}$ for several months. Even then thalli should probably grow for several seasons to reach maturity. This would approximately correspond with a mean temperature of $22-23^{\circ} \mathrm{C}$ in February (incidental warmer winters could 
be survived as crusts). The $22-23^{\circ} \mathrm{C}$ winter isotherm in the Atlantic is far more to the south than the actual southern phytogeographic boundary (Fig. 15).

Another possible southern boundary might be set by the inability of spores to germinate at temperatures above $20^{\circ} \mathrm{C}$. This suggests a "southern germination boundary" roughly on the $20^{\circ} \mathrm{C}$ winter isotherm, as occasional higher winter temperatures could be survived as basal crusts. Again, the $20^{\circ} \mathrm{C}$ winter isotherm is far more to the south than the actual southern boundary.

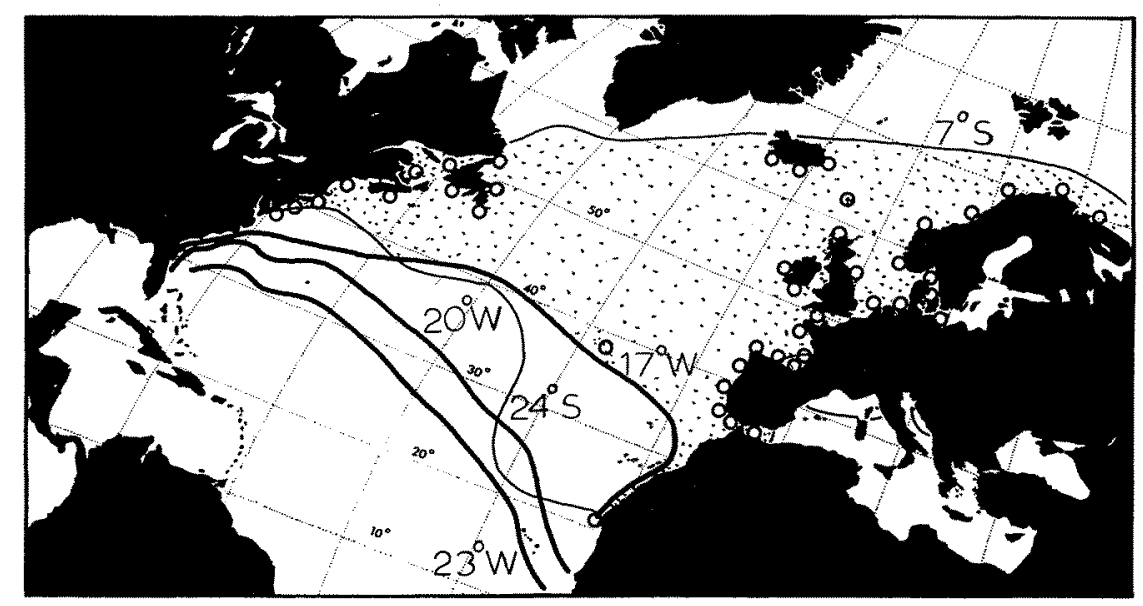

Fig. 15. Distribution of Chondrus crispus in the North Atlantic Ocean

A southern reproduction boundary can be expected at a point where temperature drops, in winter, below about $17^{\circ} \mathrm{C}$ for several months (as reproductive cells are formed at $15^{\circ} \mathrm{C}$, and not at $20^{\circ} \mathrm{C}$ ). This would correspond with a $17^{\circ} \mathrm{C}$ mean February temperature, as occasional warmer winters can be survived. This explains indeed the occurrence of C. crispus in Mauritania (W. Africa) where especially winter upwelling provides cool surface water of $16^{\circ} \mathrm{C}$. It also explains the absence of $C$. crispus in the Canaries and Madeira (where winter temperatures are about $18^{\circ} \mathrm{C}$ ) and its presence on the Azores.

The "southern lethal boundary" can be expected where during one week, temperature of the surface water exceeds c. $27^{\circ} \mathrm{C}$ in an excessively warm summer. This corresponds approximately with a mean August temperature of $24^{\circ} \mathrm{C}$. This would suggest a "southern lethal boundary" near the $24^{\circ} \mathrm{C}$ summer isotherm, which is near the actual southern limit of Chondrus crispus in America on the coast of Delaware (Zaneveld, 1972) and in Africa on the coast of Mauritania (Lawson \& John, 1977). However, the species is not recorded for the coasts between southern Portugal and Mauritania. In southern Portugal the species is rare and the plants remain small. Here the mean August temperature of the surface water is $20^{\circ} \mathrm{C}$, and the maximum temperature $23^{\circ} \mathrm{C}$. Comparable conditions exist on the Côte Basque (S.W. France) where the species is rare and intermittently present. Winter temperatures are here certainly low enough for reproduction. In southern Portugal low littoral and upper sublittoral populations run a much greater risk of being exposed to high air temperatures than in northern Portugal. In $\mathrm{S}$. Portugal the number of days per month with a temperature of $25^{\circ} \mathrm{C}$ or more is 26 or 
less per month (with maxima in July and August); in N. Portugal (where Chondrus abounds) only 6 days or less (Ardré, 1971).

One would expect $C$. crispus in the N. Mediterranean within the $24^{\circ} \mathrm{C}$ summer isotherm. Probably life is too hazardous here on the limits of its existence and without the possibility of being reestablished from more northern populations.

The "northern growth and reproduction boundary" can be expected near a point where temperatures rise in summer several months above $5^{\circ} \mathrm{C}$. Even then the thalli should probably have perennial growth before becoming mature. Excessively cold summers are probably survived as basal crusts. This would approximately correspond with a mean August temperature of $7^{\circ} \mathrm{C}$. The actual northern boundary is indeed near to the $7{ }^{\circ} \mathrm{C}$ summer isotherm. In Iceland, the species is restricted to the southern and southwestern coasts (Jónsson, 1912; Munda, 1977, 1978, 1980).

No experimental data are available to infer the "northern lethal boundary", but Chondrus crispus must be able to survive, in the Gulf of St. Lawrence, temperatures below $0{ }^{\circ} \mathrm{C}$. Basal crusts in the intertidal zone can probably survive exposures to severe frost.

\section{Geographic boundaries in the North Atlantic and North Pacific Oceans}

Chondrus crispus is also known to occur along the northwestern coasts of the Pacific Ocean, where it also seems to be bounded by the $7^{\circ} \mathrm{C}$ summer isotherm to the north and the $24^{\circ} \mathrm{C}$ summer isotherm to the south (Fig. 16). It is missing along the northeastern coasts of the Pacific Ocean which it seems to be potentially capable of inhabiting. This distribution pattern resembles very much that of Dumontia contorta and Cladophora rupestris (van den Hoek, 1979, 1982).

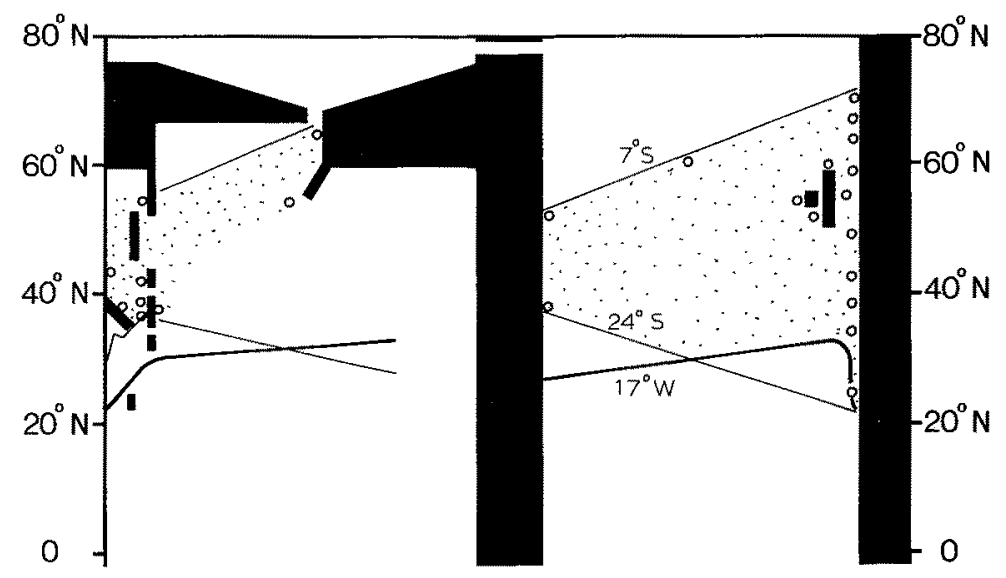

Fig. 16. Distribution of Chondrus crispus in the North Atlantic and North Pacific Oceans. The distribution data from the Bering Sea and Unalaska (Aleutian Islands) (Dawson, 1946) need confirmation

An explanation for this distribution pattern is that Chondrus crispus has succeeded in spreading from the Atlantic Ocean, through the Canadian Arctic and the Bering Straits into the Pacific Ocean during a warmer pleistocene interglacial period than the present one. This would have required summer temperatures of $7^{\circ} \mathrm{C}$ in Canadian Arctic 
Waters. At present summer surface temperatures range from $2.2{ }^{\circ} \mathrm{C}$ in the western part to $6.4^{\circ} \mathrm{C}$ in Baffin Bay (Lee, 1973), while at some points summer temperature may be as high as $9^{\circ} \mathrm{C}$ (Lee, 1980).

The southward currents (East Kamchatka Current, Oyashio Current) along the Asian shores have possibly promoted C. crispus' further dispersal to Japan; the northward current along the Alaskan shores having prevented its dispersal along American shores.

The genus Chondrus is represented in Japan by seven highly variable species. Possibly C. crispus, upon its arrival in Japan, has given rise to intense speciation. Alternatively, Chondrus crispus may have originated in Japan and dispersed through the Bering Straits and the Canadian Arctic to the Atlantic Ocean. The direction of the currents in the North Pacific Ocean does not support this hypothesis; whereas the general southeasterly direction of the currents through the Canadian Arctic Archipelago does support this hypothesis.

However, it seems unlikely that a benthic algal species could not disperse along an uninterrupted coastline within its temperature boundaries, even against the prevalent direction of the currents. Another explanation is that true Chondrus crispus does not occur along Japanese and adjacent coasts; this is the case according to J. McLachlan (pers. comm.).

\section{Desmarestia aculeata}

\section{Life history}

Desmarestiales resemble Laminariales in having a markedly heteromorphic life history, in which macroscopic sporophytes alternate with microscopic dioecious gametophytes with oogamy.

The perennial sporophytes become fertile in autumn, and show active growth in the early summer. The gametophytes produce gametes which give rise to new sporophytes which appear in spring (Chapman \& Burrows, 1970, 1971; Kornmann, 1962c).

Female gametophytes of $D$. aculeata became fertile at $5{ }^{\circ} \mathrm{C}$ and $10^{\circ} \mathrm{C}$, but not at $15^{\circ} \mathrm{C}$ and $20^{\circ} \mathrm{C}$; those of $D$. viridis at $5^{\circ} \mathrm{C}$, less than $10 \%$ at $10^{\circ} \mathrm{C}$, and not at $15^{\circ} \mathrm{C}$ and $20^{\circ} \mathrm{C}$ (Lüning, 1981a). Photoperiod did not influence fertility of the gametophytes. The factors influencing sporulation of the sporophyte were not investigated. Sporophytes of D. aculeata grew at temperatures from $0{ }^{\circ} \mathrm{C}$ through $20^{\circ} \mathrm{C}$, but not at $25^{\circ} \mathrm{C}$. The optimum temperature for growth was $10^{\circ} \mathrm{C}$ (Fortes \& Lüning, 1980).

\section{Geographic distribution in the North Atlantic Ocean}

The southern limits of $D$. aculeata and $D$. viridis along European shores can be explained as "southern reproduction boundaries" along the $12{ }^{\circ} \mathrm{C}$ and $10^{\circ} \mathrm{C}$ winter isotherms, respectively. These correspond with maximum winter temperatures of $14{ }^{\circ} \mathrm{C}$ in $D$. aculeata, and $12^{\circ} \mathrm{C}$ in $D$. viridis, allowing fertility of the female gametophytes at the southern boundaries. This is supported by the above cited experimental data (Lüning, 1981a). The southern boundaries in America are likely to be "southern lethal boundaries" and to follow consequently summer isotherms (Fig. 17).

The southern boundaries of both $D$. aculeata and $D$. viridis in N.E. America are near the $20^{\circ} \mathrm{C}$ summer isotherm, which would correspond with a lethal temperature of approximately $23^{\circ} \mathrm{C}$. This accords with the observation that growth of $D$. aculeata 


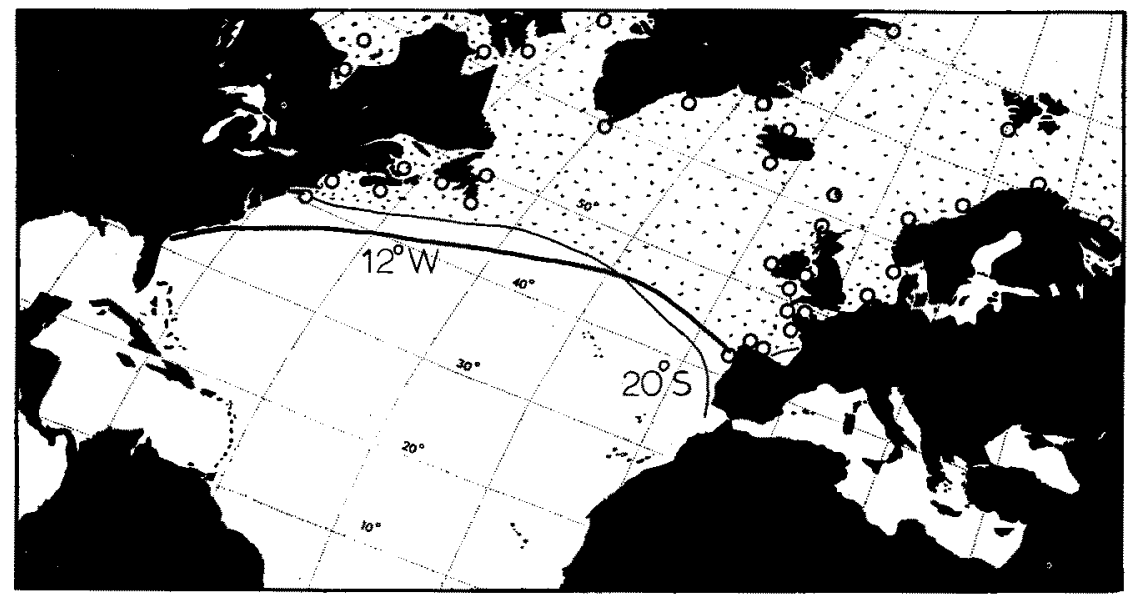

Fig. 17. Distribution of Desmarestia aculeata in the North Atlantic Ocean

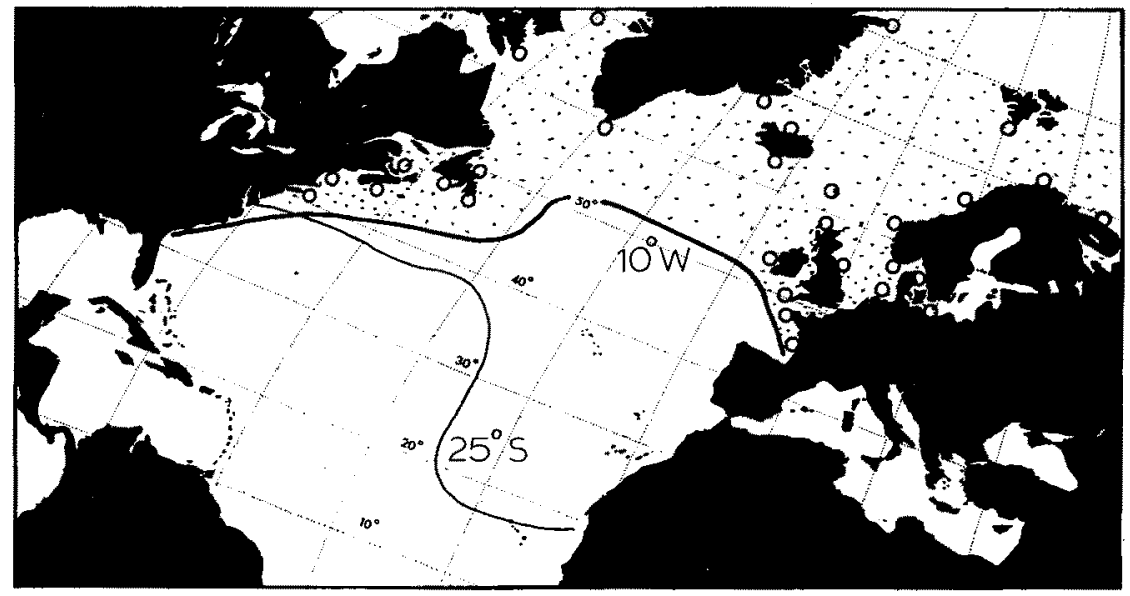

Fig. 18. Distribution of Desmarestia viridis in the North Atlantic Ocean

sporophytes ceases at a temperature between $20^{\circ} \mathrm{C}$ and $25^{\circ} \mathrm{C}$. For $D$. viridis similar observations on growth of the sporophyte are not available.

However, the southern limit of $D$. aculeata in Japan (in Sachalien and Hokkaido) is near the $17^{\circ} \mathrm{C}$ summer isotherm, and this suggests somewhat different temperature requirements of the Japanese population of $D$. aculeata. The winter temperature here is c. $0^{\circ} \mathrm{C}$, far below the maximum winter temperature allowing fertility of female gametophytes in Europe. In N.W. America the southernmost point of distribution of $D$. aculeata corresponds approximately with the $10^{\circ} \mathrm{C}$ February isotherm, and this does not differ much from the European southern limit. The mean August temperatures are here c. $14{ }^{\circ} \mathrm{C}$.

The southern limit of $D$, viridis in Japan (on the E. and W. coasts of Honshu) is situated near the $10^{\circ} \mathrm{C}$ winter isotherm and, at the same time, near the $25^{\circ} \mathrm{C}$ summer 
isotherm. In N.W. America the southern limit is near the $11^{\circ} \mathrm{C}$ winter isotherm (summer temperatures here are on an average $15^{\circ} \mathrm{C}$ ) (Fig. 18). Possibly the southern limit of $D$. viridis in N.E. America also approaches the $25^{\circ} \mathrm{C}$ August isotherm, but the lack of suitable substrata between its actual southernmost station (New Jersey) and the potential southernmost point (in Delaware), is possibly responsible for its absence in this southernmost portion of its potential range in N.E. America. Another possibility is that Japanese and N.E. American populations have somewhat different upper lethal temperatures.

\section{Distribution in the southern hemisphere}

Whereas Desmarestia viridis has been recorded from the temperate belt of the southern hemisphere, $D$. aculeata has not been recorded there. The records of $D$. viridis suggest that it is restricted to the North by the $8{ }^{\circ} \mathrm{C}$ winter isotherm, which includes the subantarctic islands and southernmost South America, but excludes Australia, New Zealand and South Africa. Papenfuß (1964) thinks that these records need confirmation. The Antarctic species $D$. willii Reinsch has formerly been confused with $D$. viridis.

\section{Monostroma grevillei}

\section{Life history}

Monostroma grevillei has a heteromorphic life history, in which blade-like dioecious gametophytes alternate with unicellular "Codiolum-like" sporophytes (Kornmann, 1962a; Jónsson, 1968; for a review, see Tatewaki, 1972). The blade-like gametophyte is a spring annual. The species survives the rest of the year in the form of the unicellular sporophyte which in this respect resembles hypnozygotes of numerous freshwater Chlorophyceae.

The sporophyte becomes fertile (produces quadriflagellate meiospores) under short

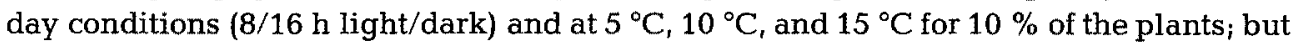
not at $1{ }^{\circ} \mathrm{C}$ and $20^{\circ} \mathrm{C}$. The sporophytes remain sterile under long day conditions $(16 / 8 \mathrm{~h}$ light/dark) and at all temperatures tested. A light break given in the long dark period reverses the photoperiodic response, this indicating a "true photoperiodic response" (Lüning, 1981a, b).

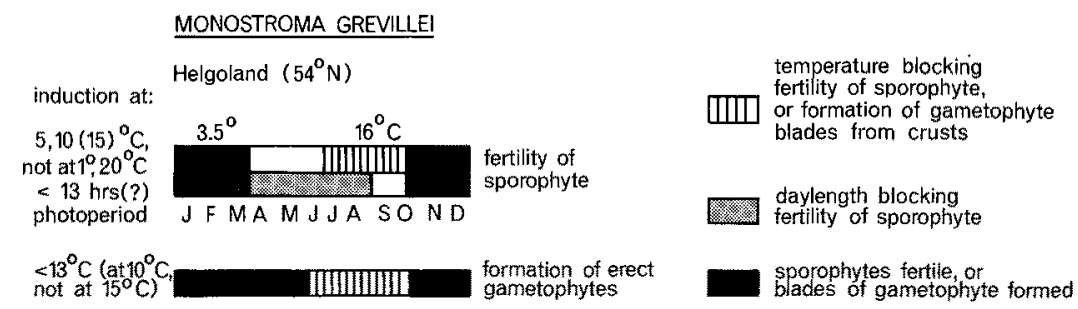

Fig. 19. Model of the seasonal sequence of events in the life history of Monostroma grevillei on Helgoland (based on Lüning, 1981a, b). The model is approximative, as the critical daylength has not been established, and the number of temperature values tested is too limited. A critical daylength has been assumed of $13 \mathrm{~h}$ (the critical daylength of Scytosiphon lomentaria on Helgoland, see Lüning, 1981a, b) 
The development of the blade-like fronds of the gametophyte from a basal crustose phase takes place at $5^{\circ} \mathrm{C}$ and $10^{\circ} \mathrm{C}$, but not at $15^{\circ} \mathrm{C}$ and $20^{\circ} \mathrm{C}$ (Lüning, 1981a).

The presumed sequence of events in the life history of $M$. grevillei on Helgoland is given in the model of Fig. 19.

\section{Distribution in the North Atlantic Ocean}

The southern limits of Monostroma grevillei along European (and N.W. American) shores, can be explained as a "southern reproduction boundary" along the $12^{\circ} \mathrm{C}$ February isotherm (Fig. 20). This is supported by Lüning's experimental data indicating a maximum temperature of $15^{\circ} \mathrm{C}$ allowing fertility of the sporophyte (this corresponds with a mean maximum temperature of inshore water of about $15^{\circ} \mathrm{C}$ and a mean February temperature of $13^{\circ} \mathrm{C}$ ).

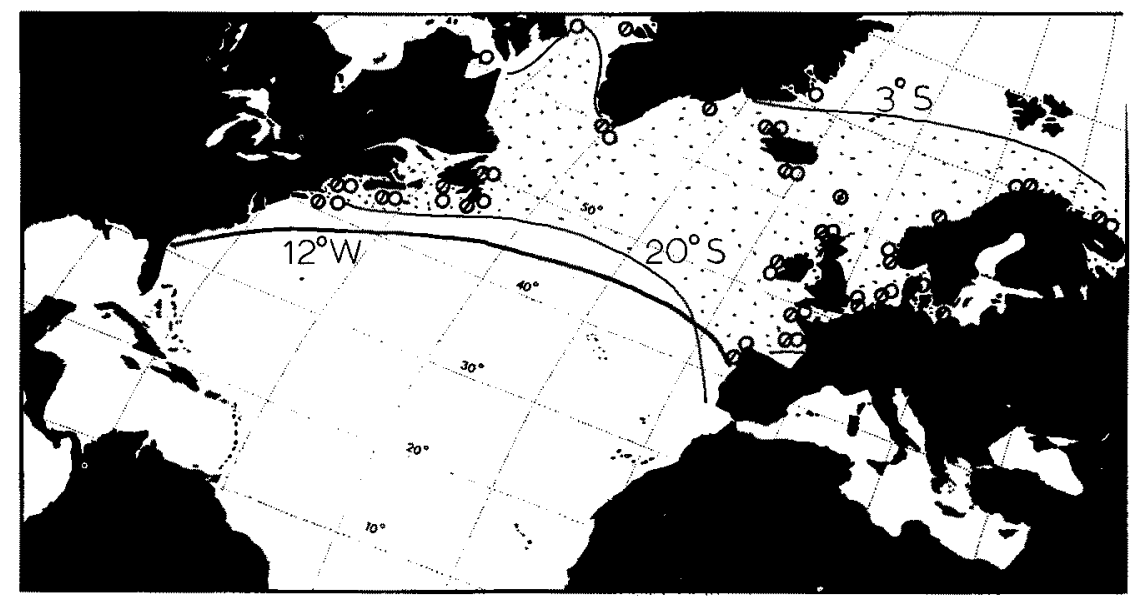

Fig. 20. Distribution of Monostroma grevillei (()) and Acrosiphonia "arcta" $(\mathrm{O})$ in the North Atlantic Ocean

The southern limits in N.E. America (and in Japan) are likely to be "southern lethal boundaries" approximately along the $20^{\circ} \mathrm{C}$ summer isotherm, which would correspond with a lethal temperature of about $23^{\circ} \mathrm{C}$. This should be the lethal temperature of the sporophyte, which is the "over-summering" phase. Lethal temperatures have not been experimentally tested so far.

The northern limit of M. grevillei in the North Atlantic Ocean can be explained as a "northern reproduction boundary" along the $3^{\circ} \mathrm{C}$ August isotherm. This is supported by Lüning's (1981b) observation that sporophytes need a minimum temperature somewhere between $1{ }^{\circ} \mathrm{C}$ and $5^{\circ} \mathrm{C}$ to become fertile. This minimum temperature should be realized in the period with sufficiently short daylengths, in early autumn (cf. Fig. 15).

Distribution in the southern hemisphere

M. grevillei has been recorded from the southern hemisphere (Fuegia and Kerguelen Islands) (Papenfuß, 1964). However, the taxonomic status of these records is uncertain, and the Monostroma-like Chlorophyceae in the southern hemisphere are in need of revision. 
Acrosiphonia "arcta"

Life history

Acrosiphonia arcta has a heteromorphic life history comparable to that of $M$. grevillei, in which monoecious isogamous gametophytes alternate with unicellular "Codiolum"-like sporophytes. The gametophytes are tufts of branched uniseriate filaments composed of multinucleate cells (Jónsson, 1962, as A. spinescens). The taxonomy of this genus is presently confused and needs revision for a large area (cf. Kormmann, 1962b; Kornmann \& Sahling, 1977). It is likely, however, that records of $A$. arcta and $A$. spinescens (or Spongomorpha arcta and $S$. spinescens) in the N. Atlantic refer to the same species. It is not clear whether the population of $A$. arcta on Helgoland, which lacks a "Codiolum phase" but is morpholigically similar to A. arcta populations with a sporophytic phase, deserves the status of a separate species (Kornmann, 1962b; Kornmann \& Sahling, 1977).

\section{Geographic distribution}

The southern distribution of $A$. arcta in the North Atlantic is identical to that of Monostroma grevillei (Fig. 20). This suggests the same causes of this distribution pattern as in $M$. grevillei, particularly so because both species have similar life histories. Experimental evidence in support of this hypothesis is not available.

A. arcta is also recorded from the N.W. Pacific Ocean where it is bounded to the south approximately by the $20^{\circ} \mathrm{C}$ summer isotherm (as in the N.W. Atlantic Ocean). $S$. arcta is also recorded from the N.E. Pacific Ocean (as Spongomorpha arcta and $S$. spinescens, cf. Scagel, 1966), where it can hardly be differentiated from Spongomorpha coalita (Rupr.) Coll. This latter species has its southern boundary at about the $12{ }^{\circ} \mathrm{C}$ winter isotherm.

Acrosiphonia arcta has also been recorded from the southern hemisphere (as Spongomorpha arcta and $S$. spinescens), where it occurs south of the $12{ }^{\circ} \mathrm{C}$ winter isotherm. However, the taxonomic status on the species level of these southern records is uncertain (Papenfuß, 1964).

\section{The amphiatlantic temperate group with a southern boundary near a winter isotherm}

The species of the Cladophora albida type are characterized by having winter isotherms as their southern boundaries: these correspond with "southern growth and/or reproduction boundaries" (Fig. 3).

Punctaria latifolia seems to be, on the basis of its distribution, another example of this distribution group. Two other examples, Scytosiphon lomentaria and Petalonia fascia, have been treated elsewhere (van den Hoek, 1982).

\section{Punctaria latifolia}

\section{Life history}

The life history of Punctaria latifolia comprises a prostrate filamentous phase with apical growth (the microthallus phase) from which erect lanceolate blades arise with 
intercalary growth (the macrothallus phase). Both microthallus phase and macrothallus phase reproduce only by plurilocular zoidangia in one strain from the Netherlands (Rietema \& van den Hoek, 1981). All plurizoids grow into new microthalli; macrothalli can only be formed as shoots from microthalli.

In other strains pluri- als well as unilocular zoidangia are formed whose zoids also directly grow into new microthalli. There are no clear indications of a sexual cycle (Dangeard, 1963, 1966; Clayton \& Ducker, 1970).

The initiation of macrothalli in the above strain from the Netherlands was markedly influenced by temperature (Rietema \& van den Hoek, 1981: as Desmotrichum undulatum). Higher temperatures $\left(20^{\circ}, 25^{\circ}, 30^{\circ} \mathrm{C}\right)$ favoured the rapid development of ephemerous, predominantly uniseriate macrothalli which disintegrated soon (within 1-2 weeks) by intensive sporulation. $16^{\circ} \mathrm{C}$ was the highest temperature allowing the formation of lanceolate macrothalli which, however, reached their maximum size within 2-4 weeks, when intensive sporulation put an end to vegetative growth. At still lower temperatures $\left(4^{\circ}, 8^{\circ}, 12^{\circ} \mathrm{C}\right)$ the final size of the macrothalli was much larger, despite slower growth. This was caused by a much later onset of zoidogenesis at lower temperatures (at $12{ }^{\circ} \mathrm{C}$ after $3-4$ weeks, at $8{ }^{\circ} \mathrm{C}$ after $4-8$ weeks, and at $4{ }^{\circ} \mathrm{C}$ after $8-13$ weeks). Under short day conditions the onset of zoidogenesis was advanced, particularly so at lower temperatures. Therefore the largest blades were formed at lower temperatures and long day conditions, that is, in late spring.

At $30^{\circ} \mathrm{C}$ growth was abnormal and characterized by disintegration by precocious and abundant zoidogenesis of microthalli and abortive macrothalli. At $35^{\circ} \mathrm{C}$ microthalli died.

In culture, widely varying macrothalli were obtained embracing the characters of Desmotrichum balticum Kütz., D. scopulorum Reinke, D. undulatum (J. Ag.) Reinke, and Punctaria latifolia Grev. (Rietema \& van den Hoek, 1981).

Punctaria crouanii (Thur.) Born. and P. crispata (Kütz.) Batt. probably also belong to the range of $P$. latifolia.

\section{Geographic distribution in the North Atlantic Ocean}

The southern limit along the N.E. Atlantic shores at the $14{ }^{\circ} \mathrm{C}$ winter isotherm (Fig. 21) can be explained as a "southern growth boundary", corresponding with the highest winter temperature $\left(16^{\circ} \mathrm{C}\right)$ allowing the formation of macrothalli from microthalli. This is in accordance with the above experimental results.

The southern limit along the N.W. Atlantic shores (at Beaufort, N. Carolina) near the $27^{\circ} \mathrm{C}$ summer isotherm can be explained as a "southern lethal boundary", corresponding with a lethal temperature of $\mathrm{c} .30^{\circ} \mathrm{C}$. This accords with the above experimental results, which indicated abnormal growth at $30^{\circ} \mathrm{C}$ and a lethal temperature limit between $30^{\circ} \mathrm{C}$ and $35^{\circ} \mathrm{C}$. This explanation of the southern limit of $P$. latifolia differs from that given in Rietema \& van den Hoek (1981), where the $15^{\circ} \mathrm{C}$ winter isotherm ("the southern growth boundary") is considered to limit $P$. latifolia to the south both in Europe and N.E. America. However, in that case the southernmost point of $P$. latifolia could be expected much more to the south in N.E. America than the actual, southernmost limit at Beaufort, N. Carolina.

Apparently, the southern limit of $P$. latifolia does not differ from most other southern limits so far investigated in the North Atlantic Ocean. It is also of a composite nature, and 
consists along the E. Atlantic coast of a "southern growth boundary" (a winter isotherm), and along the W. Atlantic coast of a "southern lethal boundary" (a summer isotherm).

Apparently there is no fundamental difference between the Cl. rupestris-type and Cl. albida-type of the amphiatlantic distribution group. Clearly distribution data alone may lead to incorrect conclusions as to the causes of distribution patterns.

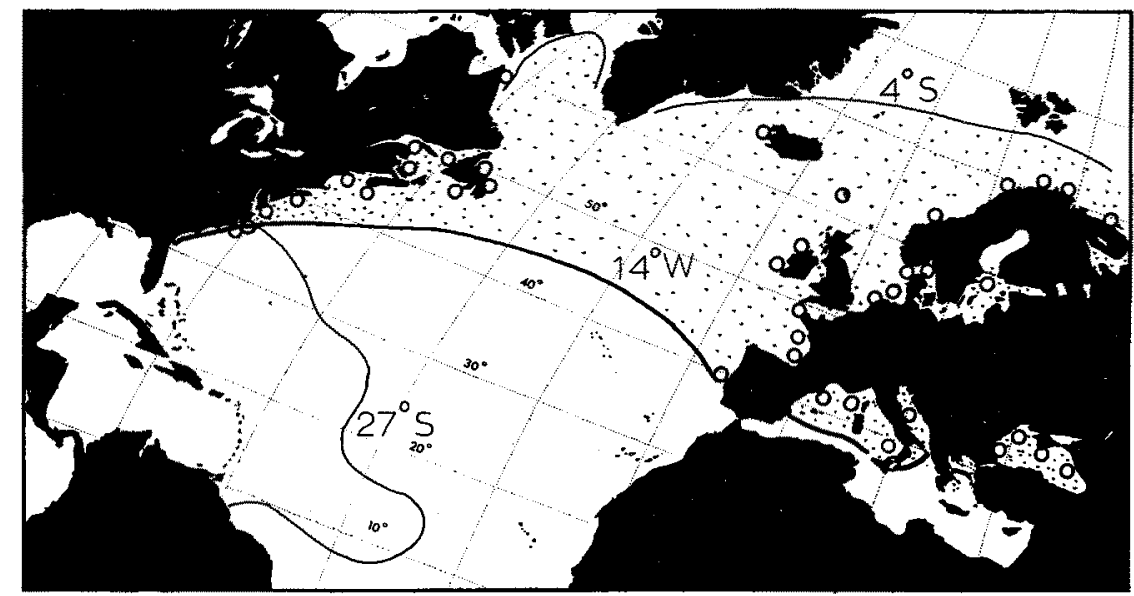

Fig. 21. Distribution of Punctaria latifolia in the N. Atlantic Ocean

So far only Scytosiphon lomentaria and Petalonia fascia seem to have southern boundaries along winter isotherms (of $17^{\circ} \mathrm{C}$ ) at both sides of the ocean and corresponding with the maximum winter temperatures allowing initiation of macrothalli. However, even in these two species a lethal temperature of c. $33^{\circ} \mathrm{C}$ probably prevents their establishment in most of the N. Gulf of Mexico.

The northern limit of $P$. latifolia (near the $4{ }^{\circ} \mathrm{C}$ winter isotherm) can probably be explained as a "northern reproduction boundary". At $4^{\circ} \mathrm{C}$ in culture slow growth of macrothalli and fertility occurred; lower temperatures were not investigated.

\section{Distribution in the Atlantic and Pacific Oceans}

The distribution pattern of $P$. latifolia in the North Pacific Ocean accords with that in the N. Atlantic Ocean with regard to the limiting isotherms (Fig. 22). The comparatively few records from the southern hemisphere are contained between the $14{ }^{\circ} \mathrm{C}$ winter isotherm to the north and the $4{ }^{\circ} \mathrm{C}$ summer isotherm to the south.

\section{The N.E. American temperate group}

The few species in this distribution group are endemic to N.E. American coasts, where they are adapted to the wide annual temperature fluctuations. Chondria baileyana is one possible example, but this species is difficult to differentiate from $C$. tenuissima. Another possible example is Polysiphonia harveyi. However, the genus Polysiphonia is in need of a taxonomic revision for large areas. 


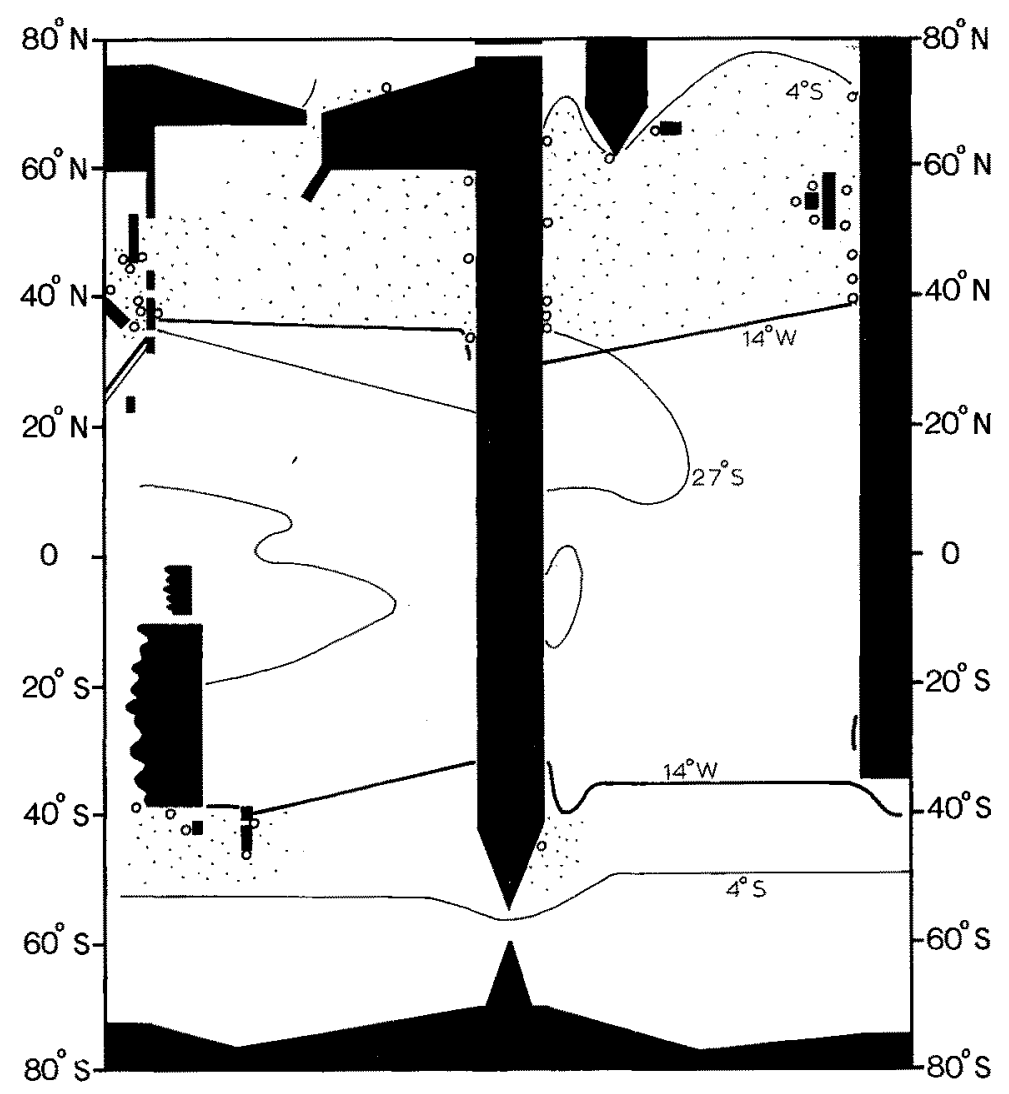

Fig. 22. Distribution of Punctaria latifolia in the Atlantic and Pacific Oceans

\section{Polysiphonia harveyi}

Life history

Polysiphonia harveyi has an isomorphic alternation between gametophytic and tetrasporophytic phases (Polysiphonia-type).

Isolates from Wrightsville Beach, North Carolina, grew well at 10, 15, 20, and $25^{\circ} \mathrm{C}$, and poorly at $30^{\circ} \mathrm{C}$. Antheridia and carpogonia were formed at $10-25^{\circ} \mathrm{C}$, mature gonimocarps at $20^{\circ} \mathrm{C} ;$ in nature gonimocarps were found at $11-23^{\circ} \mathrm{C}$ (the formation of tetrasporangia was not investigated) (Kapraun, 1980).

\section{Geographic distribution along N.E. American shores}

The northern boundary of $P$. harveyi is near the $12{ }^{\circ} \mathrm{C}$ August isotherm (Fig. 23). This limit can be explained as a "northern reproduction boundary", corresponding with a minimum summer temperature of $11^{\circ} \mathrm{C}$ necessary for the formation of mature gonimocarps.

The southern boundary of $P$. harveyi is near the $19^{\circ} \mathrm{C}$ winter isotherm. This can be explained as a "southern reproduction boundary", approximately corresponding with a 


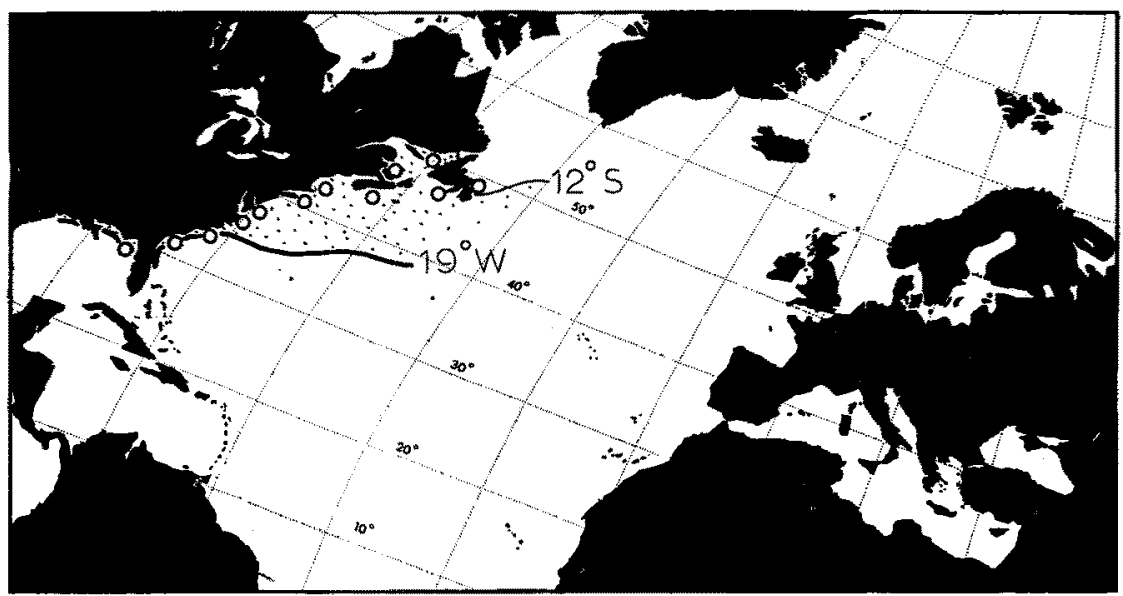

Fig. 23. Distribution of Polisiphonia harveyi in the North Atlantic Ocean

maximum summer temperature of $21^{\circ} \mathrm{C}$ allowing formation of mature gonimocarps (in nature, the highest temperature at which mature gonimocarps were found, was $23^{\circ} \mathrm{C}$ ).

At the northern boundary, $P$. harveyi is a summer annual in protected, shallow embayments; at the southern boundary it is a winter annual. At the northern boundary it must be able to survive winter temperatures as low as $-2{ }^{\circ} \mathrm{C}$; at the southern boundary summer temperatures as high as $33^{\circ} \mathrm{C}$. P. harveyi is apparently well adapted to the wide temperature fluctuations characteristic for N.E. American temperate coasts.

\section{Bonnemaisonia hamifera}

Bonnemaisonia hamifera is an invader from the Japanese temperate distribution group. This distribution group contains the numerous species endemic to Japanese and adjacent coasts (approximately between $30^{\circ} \mathrm{N}$ and $45^{\circ} \mathrm{N}$ ). This group is equivalent to the N.E. American temperate group which contains only very few endemic species.

\section{Life history}

Bonnemaisonia hamifera has a heteromorphic alternation between a perennial filamentous tetrasporophyte (microthallus-phase) and an annual dioecious erect gametophyte (macrothallus-phase) of a complex architecture. The tetrasporophyte is also known as the Trailliella-phase (Fig. 24).

In cultures from Helgoland, tetrasporangia were formed by the tetrasporophyte after exposure for about one month to a photoperiod of 11 hours or less per day and a temperature between $12^{\circ}$ and $19^{\circ} \mathrm{C}$ (Lüning, 1981a, b; see also Chihara, 1961; Chen et al., 1969). A light break during the long dark period blocked tetrasporogenesis thus indicating a true photoperiodic response. The combination of relatively high temperatures and short daylengths inducing tetrasporogenesis is realized for only a short period (October) on Helgoland, and for a longer period (November/December) at Tsuyazaki, Japan (Lüning, 1981a, b; see Fig. 24).

Gametophytes develop from the tetraspores in autumn and grow into maturity in the course of spring. The influence of photoperiod and temperature on the growth and 
BONNEMAISONIA HAMIERA

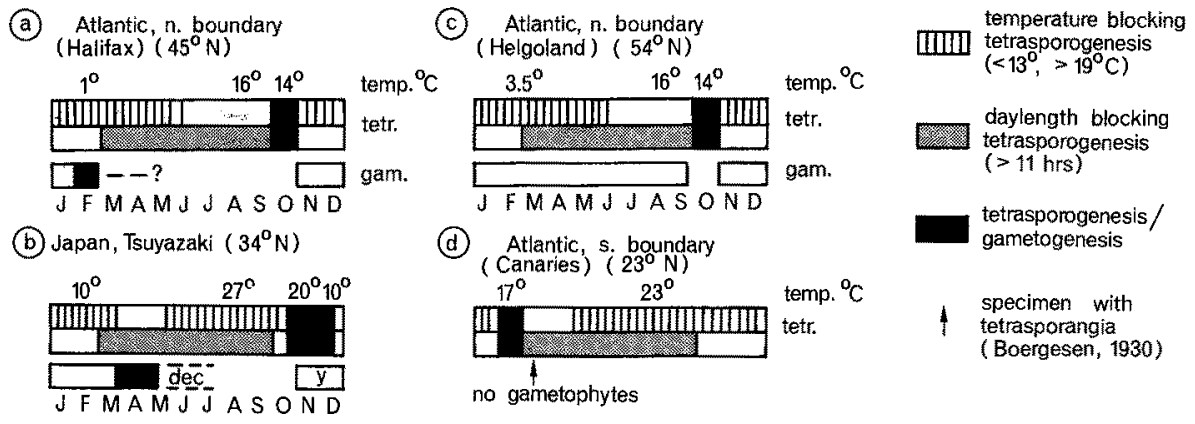

Fig. 24. Bonnemaisonia hamifera. Conditions (temperature, daylength) influencing tetrasporogenesis of tetrasporophytes. Models in which experimental results obtained in cultures of material from Helgoland are applied to field conditions at Halifax (a) (cf. Edelstein et al., 1969a, b); Tsuyazaki, Japan (b) (cf. Chihara, 1961); Helgoland, Europe (c); and Canaries (d). Tetr. = tetrasporophytes; Gam. = gametophytes; dec. = decay; $\mathrm{y}=$ young gametophytes

maturation of the gametophyte has not been experimentally investigated. However, growth of the gametophytes was clearly inhibited at temperatures higher than $20^{\circ} \mathrm{C}$ (Koch, 1950), and they died after one week of exposure to $25^{\circ} \mathrm{C}$ (they survived $23^{\circ} \mathrm{C} ;$ Lüning, $1981 \mathrm{~b})$. In short term experiments (12 h exposure) gametophytes survived $17^{\circ} \mathrm{C}$, but not $27^{\circ} \mathrm{C}$ (Biebl, 1959). Tetrasporophytes died after one week at $28^{\circ} \mathrm{C}$ (they survived $25^{\circ} \mathrm{C}$; Lüning, $1981 \mathrm{~b}$ ) and at $-2.9^{\circ} \mathrm{C}$ within two hours when ice was formed, but not when ice was not formed $(\mathrm{Koch}, 1950)$. This indicates that the Trailliella-phase can survive subtidal winter temperatures as low as $-2{ }^{\circ} \mathrm{C}$. This is also valid for the gametophyte (Koch, 1950). In short term experiments (12 h exposure) gametophytes survived $-2{ }^{\circ} \mathrm{C}$, but not $-8^{\circ} \mathrm{C}$ (with ice formation) (Biebl, 1959).

\section{Phytogeographic boundaries in the North Atlantic Ocean}

The "southern reproduction boundary" of the tetrasporophyte of Bonnemaisonia hamifera can be expected near an E-W line where, during a period of about one month, temperature drops below $19^{\circ} \mathrm{C}$ in an average winter in order to allow tetrasporogenesis and consequently the initiation of gametophytes. This would approximately correspond with a monthly mean February temperature of $19^{\circ} \mathrm{C}$ in the sublittoral. The "southern reproduction boundry" of the tetrasporophyte can therefore be expected near the $19^{\circ} \mathrm{C}$ winter isotherm.

The "southern growth boundary" of the tetrasporophyte has not been experimentally tested, but the "southern lethal boundary" can be expected at a point where temperature never exceeds $28^{\circ} \mathrm{C}$ for one week, which corresponds with a maximum August temperature of about $28^{\circ} \mathrm{C}$ and with a mean August temperature of c. $25^{\circ} \mathrm{C}$. Thus the "southern lethal boundary" of the Trailliella-phase can be expected to approximate the $25^{\circ} \mathrm{C}$ summer isotherm, which is not far from the actual southern boundary (Fig. 25).

The "southern growth and reproduction boundary" of the gametophyte has not been experimentally tested, but the seasonal development of the gametophyte at Shimoda, Japan, suggests that temperature should drop below c. $15{ }^{\circ} \mathrm{C}$ for about four months in winter to allow sufficient growth and reproduction; this approximaly corresponds with 


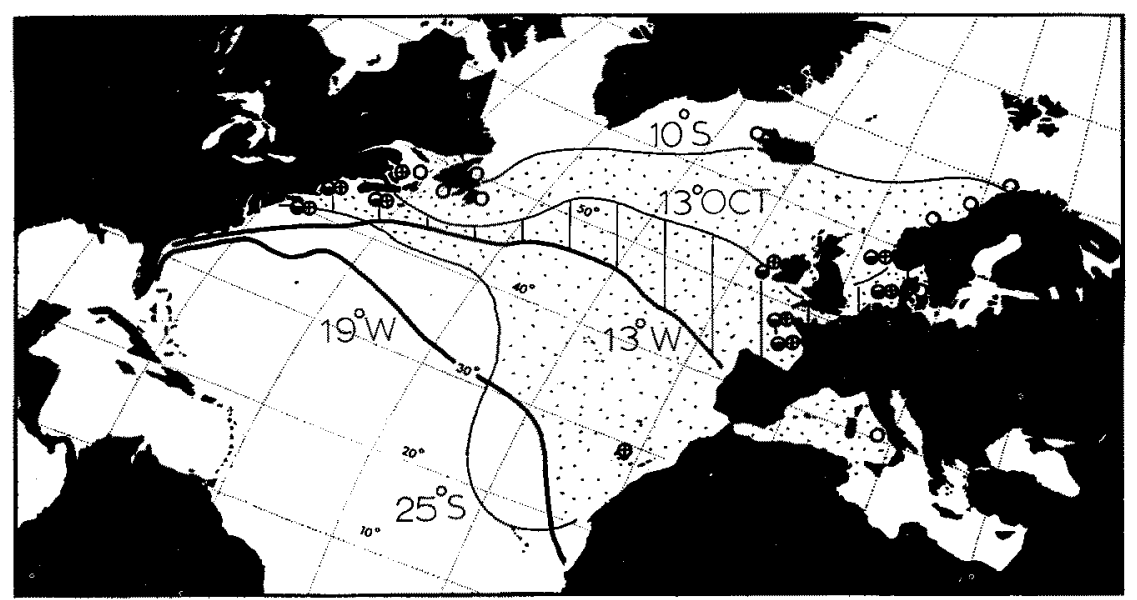

Fig. 25. Distribution of Bonnemaisonia hamifera in the North Atlantic Ocean. Hatched: distribution area of the gametophyte (ᄋ). Stippled: distribution area of the tetrasporophyte with ( $\oplus$ ) and without (0) tetraspores. $19^{\circ} \mathrm{W}=19^{\circ} \mathrm{C}$ winter isotherm. $25^{\circ} \mathrm{S}=25^{\circ} \mathrm{C}$ summer isotherm. $13^{\circ} \mathrm{Oct}: 13^{\circ} \mathrm{C}$ October isotherm. $10^{\circ} \mathrm{S}=10^{\circ} \mathrm{C}$ summer isotherm

the $13^{\circ} \mathrm{C}$ winter isotherm (Chihara, 1961, 1962). At $15^{\circ} \mathrm{C}$, normal gametophytes are obtained in culture (Chen et al., 1969). At $20^{\circ} \mathrm{C}$ growth of gametophytes is inhibited (Koch, 1950).

The "southern lethal boundary" of the gametophyte can be expected at a point where temperature exceeds $23^{\circ} \mathrm{C}$ for several weeks in summer; actually this is not relevant as the gametophyte is a spring annual which has terminated its life-span before summer.

The "northern reproductive boundary" of the tetrasporophyte can be expected near a point where, for about one month, temperature is above $12{ }^{\circ} \mathrm{C}$ in the period with the short daylengths ( $\leqslant 11 \mathrm{hrs}$ ) inducing tetrasporogenesis. This month is apparently October (Fig. 24c) and it means that the northern reproductive boundary of the tetrasporophyte approximates the $13^{\circ} \mathrm{C}$ October isotherm, which corresponds with about the $15^{\circ} \mathrm{C}$ summer isotherm in Europe and about the $16^{\circ} \mathrm{C}$ summer isotherm in N.E. America. This northern reproductive boundary of the tetrasporophyte is at the same time the northern boundary of initiation of the gametophytes (which can only start from tetraspores). The actual northern boundary of the gametophyte approximates indeed the $13^{\circ} \mathrm{C}$ October isotherm (Fig. 25).

The "northern growth boundary" of the tetrasporophyte was not investigated, but distribution data suggest that temperatures in summer must be above $8{ }^{\circ} \mathrm{C}$ for $1-2$ months to allow sufficient growth of the Trailliella-phase, which has its northern boundary near the $10^{\circ} \mathrm{C}$ summer isotherm. Trailliella can maintain itself and disperse by means of vegetative multiplication by fragmentation.

The "northern lethal boundary" of the tetrasporophyte can be expected at $-2{ }^{\circ} \mathrm{C}$. Its occurrence in waters around Labrador indicates that it can indeed survive temperatures of $-2{ }^{\circ} \mathrm{C}$. Mature gametophytic plants were present in February on the Atlantic coast of Nova Scotia in water with a temperature of $2^{\circ} \mathrm{C}$ (Chen et al., 1969); this indicates that the 
gametophyte must be able to grow and reproduce at considerably lower temperatures than the tetrasporophyte.

The various above-treated boundaries have been integrated in Fig. 25 which shows that $B$. hamifera gametophytes occupy only a narrow latitudinal belt both in N.E. America and along European shores. This belt is limited to the North by the "northern reproductive boundary" of the tetrasporophyte, which is near the $13^{\circ} \mathrm{C}$ October isotherm; and to the south by the "southern growth and reproduction boundary" of the gametophyte (the $13{ }^{\circ} \mathrm{C}$ winter isotherm) in Europe, and the "southern lethal boundary" of the tetrasporophyte in America (the $25^{\circ} \mathrm{C}$ summer isotherm).

Fig. 25 also shows that the tetrasporophyte - the Trailliella-phase - has a much wider latitudinal span than the gametophyte, and is limited to the north by the "northern growth boundary" (c. $10^{\circ} \mathrm{C}$ summer isotherm) and to the south by the "southern lethal boundary" (the $25^{\circ} \mathrm{C}$ summer isotherm). Apparently the vegetative reproduction by the tetrasporophyte is much more important than the sexual cycle.

At its northern boundary, the gametophyte can be expected to be present some years, and to be absent in other years, as Octobers colder than $13^{\circ} \mathrm{C}$ will block tetrasporogenesis. This is actually the case, in Europe (Helgoland) as well as in N.E. America (Halifax) (Lüning, 1981b; Chen et al., 1969). Comparable year-to-year fluctuations can be expected along the southern distribution boundary. The close proximity of these instable boundaries along European coasts is probably the reason that gametophytes are comparatively rare, and that female gametophytes often fail to become fertilized (Hamel, 1930) probably because male and female gametophytes are too scattered.

\section{Distribution in Japan}

Bonnemaisonia hamifera is thought to have been accidentally introduced into the North Atlantic Ocean from Japan at the end of the previous century (McLachlan et al., 1969; Lüning, 1981b). The vehicle for this introduction is unknown. The species has probably also been introduced to Pacific American coasts.

The distribution of Bonnemaisonia hamifera in Japan is given in Fig. 26. Apparently the southern distribution boundaries of the tetrasporophyte and gametophyte phase are more or less congruent. The $27^{\circ} \mathrm{C}$ summer isotherm is the "southern lethal boundary" of the tetrasporophyte. The $13^{\circ} \mathrm{C}$ winter isotherm is the "southern growth and reproduction boundary" of the gametophyte.

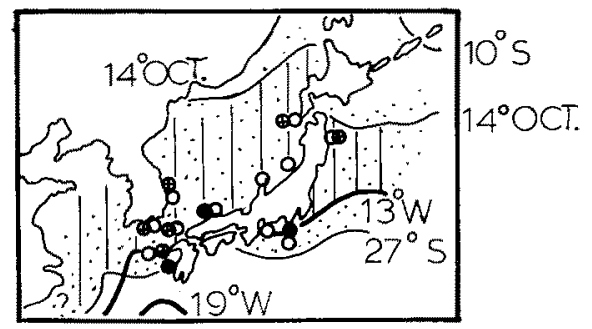

Fig. 26. Distribution of Bonnemaisonia hamifera in Japan. Stippled: distribution area of the tetrasporophyte $(\oplus)$. Hatched; distribution area of the gametophyte $(0) .10^{\circ} \mathrm{S}=10^{\circ} \mathrm{C}$ summer isotherm. $14^{\circ} \mathrm{Oct} .=14^{\circ} \mathrm{C}$ October isotherm. $13^{\circ} \mathrm{W}=13^{\circ} \mathrm{C}$ winter isotherm. $27^{\circ} \mathrm{S}=27^{\circ} \mathrm{C}$ summer isotherm. $19^{\circ} \mathrm{W}=19^{\circ} \mathrm{C}$ winter isotherm 
The $19^{\circ} \mathrm{C}$ winter isotherm is the "southern reproductive boundary" of the tetrasporophyte; this does not function as a real boundary, as it is situated to the south of the "southern lethal boundary".

To the north the $14{ }^{\circ} \mathrm{C}$ October isotherm corresponds with the "northern reproductive boundary" of the tetrasporophyte in Japan. Purely vegetative tetrasporophytes can be expected up to the $10^{\circ} \mathrm{C}$ summer isotherm in the Kurillian Isles $\left(45^{\circ} \mathrm{N}\right)$. No distribution data are available to corroborate this. To the south, gametophytes and tetrasporophytes can be expected to occur along Chinese coast (to about $25^{\circ} \mathrm{N}$ ); distribution data for the Chinese coasts could not be obtained.

The much better congruence of the distributional boundaries of B. hamifera in Japan than in Europe, supports the opinion that this species is a native of Japan where it is adapted to the prevailing temperature conditions. Temperature conditions along European coasts have enabled the tetrasporophyte to disperse, in the course of the past decades, through a much wider latitudinal span than it inhabits in Japan, whereas completion of the sexual cycle is more difficult than in Japan because conditions inducing tetrasporogenesis - mainly the sharp autumnal temperature drop coinciding with short daylengths - are less easily realized. The vigorous vegetative multiplication of the tetrasporophyte is a necessary prerequisite for its successful dispersal in Europe.

It is interesting that many other species which are considered to be characteristic for the Japan Sea shores of Japan, such as Coccophora langsdorfii, Grateloupia divaricata, and Sargassum confusum have comparable distribution patterns along the coasts of Japan (Chihara \& Yoshizaki, 1970; cf. Funahashi, 1974).

\section{Distribution along Pacific North American shores}

Bonnemaisonia hamifera is in Pacific North America (Fig. 27) an infrequent species which is restricted to a narrow latitudinal belt between Point Conception $\left(34^{\circ} 30^{\prime}\right)$ and Punta San Quintìn (c. $30^{\circ} \mathrm{N}$ ). In this belt, temperatures in the short day period (October through February) may have values inducing the formation of tetrasporangia, namely $13^{\circ}-19^{\circ} \mathrm{C}$, with annual fluctuations (mean monthly values) of c. $12-15^{\circ} \mathrm{C}$ at $34^{\circ} 30^{\prime}$, and

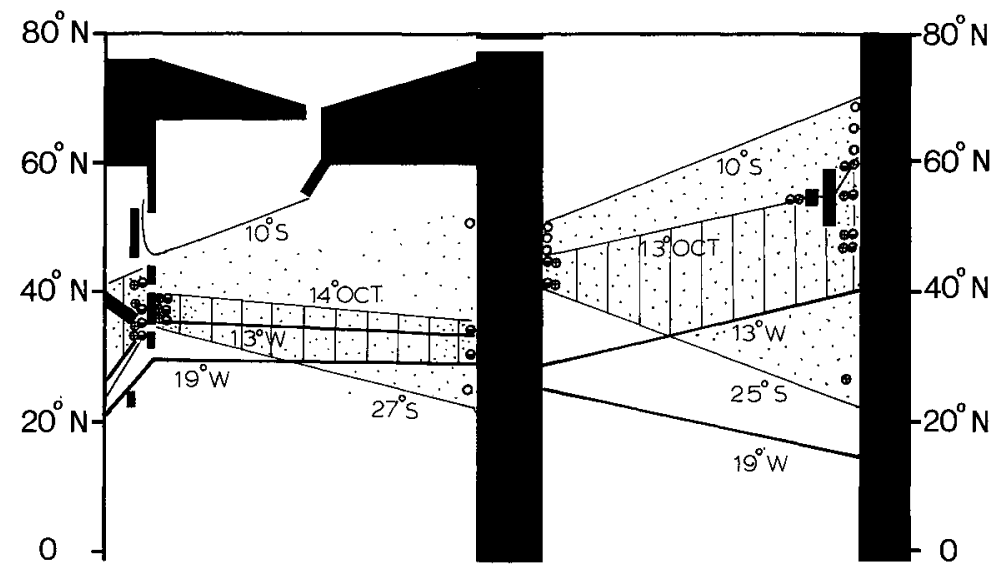

Fig. 27. Distribution of Bonnemaisonia hamifera in the North Pacific and North Atlantic Oceans. (For explanation of symbols, see text to Fig. 25) 
$17-20^{\circ}$ at $30^{\circ}$. This southern boundary of the gametophyte apparently has the character of "the southern reproductive boundary" of the tetrasporophyte, as gametophytes can only grow from tetraspores. It approximates the $19^{\circ} \mathrm{C}$ winter isotherm. The northern boundary of the gametophyte corresponds in the same way with the "northern reproductive boundary" of the tetrasporophyte $\left(14^{\circ} \mathrm{C}\right.$ October isotherm). North of Point Conception the temperatures are too low throughout the year for tetrasporogenesis (less than

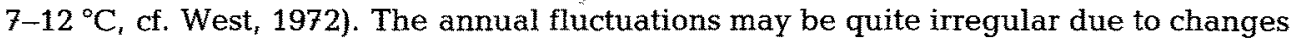
in upwelling and circulation. In other words: there is not a distinct autumnal drop in temperature which times, together with short photoperiod, the onset of tetrasporogenesis, such as it does in Japan. Temperatures can be expected to be occasionally too high or too low for tetrasporogenesis, thus causing an irregular presence of the gametophytes in the winter half year. Moreover, temperatures should remain below $15^{\circ} \mathrm{C}$ in the winter half year in order to allow growth and maturation of the gametophyte.

The tetrasporophyte has a much wider latitudinal distribution, although it has not been found throughout its potential range (especially towards the north).

Apparently $B$. hamifera is as poorly adapted to temperature conditions in N.W. America as it is in Europe.

\section{The warm temperate Mediterranean-Atlantic distribution group}

This distribution group contains the species endemic to European temperate shores (Fig. 4; see "Introduction"). The distribution of Acrosymphyton purpuriferum suggests that this species belongs to this distribution group (Fig. 29). The following discussion, however, will present arguments to attribute $A$. purpuriferum rather to distribution group 1, the amphiatlantic tropical-to-temperate distribution group with a northeastern extension (Fig. 1).

\section{Acrosymphyton purpuriferum}

\section{Life history}

A. purpuriferum has a heteromorphic alternation between a perennial crustose tetrasporophyte (microthallus) and an annual erect monoecious gametophyte (CortelBreeman \& van den Hoek, 1970). In cultures from Banyuls (S. France) tetrasporangia were formed after exposure, for at least one week, to a photoperiod of $13 \mathrm{hrs}$ or less and a

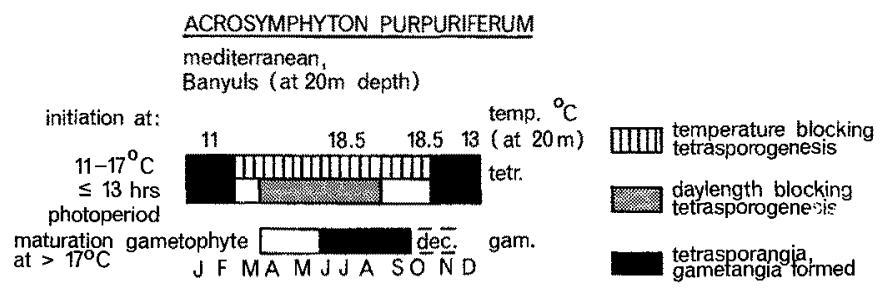

Fig. 28. Acrosymphyton purpuriferum. Conditions (temperature, daylength) influencing tetrasporogenesis and gametogenesis. Model in which experimental results obtained from cultures of material from Banyuls are applied to field conditions at Banyuls (at $20 \mathrm{~m}$ depth). Based on Breeman (1979). Tetr. = tetrasporophyte; Gam. = gametophyte; dec. = decay 
temperature between $11^{\circ}-17^{\circ} \mathrm{C}$. The combined influence of temperature and short photoperiods restricts the formation of tetrasporangia to the period November through February at a depth of $20 \mathrm{~m}$ at Banyuls (Fig. 28). Young gametophytes appear in spring, and mature in the course of spring and summer. They matured at temperatures above $17^{\circ} \mathrm{C}$ (and up to $27^{\circ} \mathrm{C}$ ) without a photoperiodic influence (Breeman, 1979, with further references). Vegetative growth of the gametophytes took place over the entire temperature range experimentally tested $\left(12^{\circ} \mathrm{C}-28^{\circ} \mathrm{C}\right)$. The perennial tetrasporophytes are probably capable of vegetative multiplication by means of vegetative fragments. Vegetative growth of tetrasporophytes took place over the entire temperature range experimentally tested $\left(8^{\circ} \mathrm{C}-20^{\circ} \mathrm{C}\right)$. Lethal temperatures were not investigated.

The unique type of photoperiodic response in Acrosymphyton is presently further being investigated (Cortel-Breeman \& ten Hoopen, 1978; ten Hoopen \& Breeman, in prep.).

\section{Phytogeographic boundaries}

The "southern reproduction boundary" of the microthallus-phase of Acrosymphyton purpuriferum can be expected near a point where, during a period of at least two weeks, temperature drops below $17^{\circ} \mathrm{C}$ in most winters in order to allow tetrasporogenesis and consequently the initiation of gametophytes: this on the assumption that Atlantic populations have the same temperature and daylength requirements as strains from Banyuls. This would approximately correspond with a monthly mean temperature of $17^{\circ} \mathrm{C}$ at the depth (15-30 m) where Acrosymphyton grows. If, in some years, temperature does not drop below $17^{\circ} \mathrm{C}$ it can survive as the perennial crust with its own vegetative multiplication. This boundary can therefore be expected to approximate the $17^{\circ} \mathrm{C}$ winter isotherm, which it does (Fig. 29) according to available distribution data.

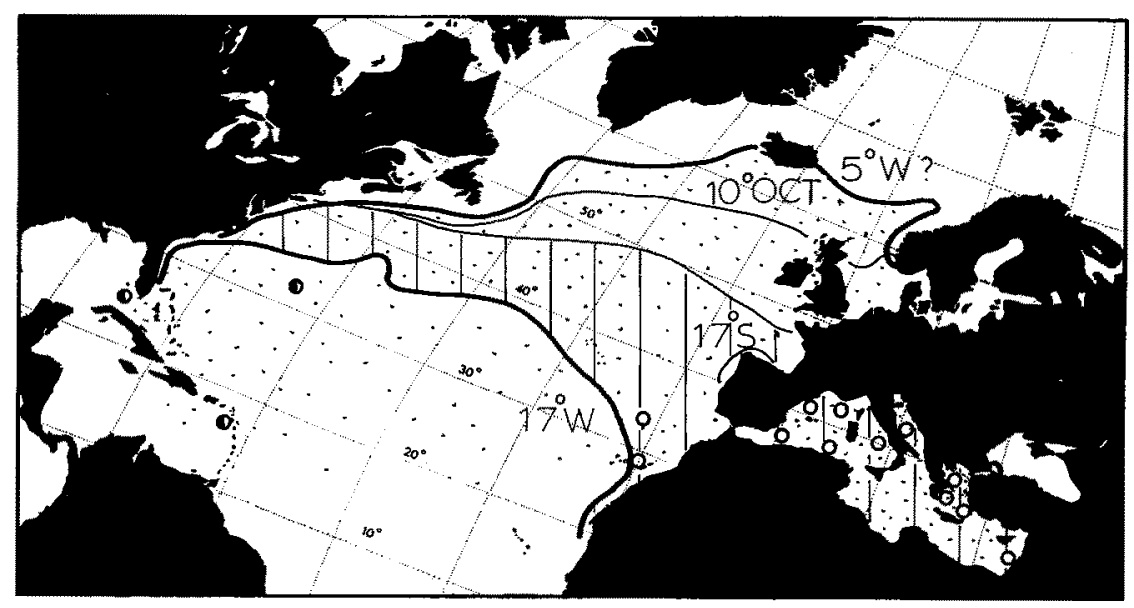

Fig. 29. Distribution of Acrosymphyton purpurifenum (O) and A. caribaeum (O) in the North Atlantic Ocean. Hatched area: potential distribution area of fertile $A$. purpuriferum gametophytes. Stippled area: potential distribution area of tetrasporophytes. $5^{\circ} \mathrm{W}=5^{\circ} \mathrm{C}$ winter isotherm; $10^{\circ} \mathrm{Oct} .=10^{\circ} \mathrm{C}$ October isotherm; $17^{\circ} \mathrm{S}=17^{\circ} \mathrm{C}$ summer isotherm; $17^{\circ} \mathrm{W}=17^{\circ} \mathrm{C}$ winter isotherm. Distribution data from Breeman (1979) 
Theoretically, the "southern growth boundary" of the microthallus-phase can be expected farther to the south as vegetative growth is possible at up to at least $20^{\circ} \mathrm{C}$.

The "northern reproduction boundary" of the microthallus-phase can be expected near a point where, during at least two weeks in the period September through March (when photoperiods are $\leqslant 13 \mathrm{hrs} / \mathrm{day}$ ), temperature remains above $10^{\circ} \mathrm{C}$ thus allowing tetrasporogenesis. This point would approximate the $10^{\circ} \mathrm{C}$ October isotherm which roughly corresponds with the $13{ }^{\circ} \mathrm{C}$ summer isotherm in Europe and about the $16^{\circ} \mathrm{C}$ summer isotherm in America. Again, purely vegetative growth and multiplication of microthalli is possible at still lower summer temperatures (down to at least $8^{\circ} \mathrm{C}$ ).

The "southern growth and reproduction boundary" of the gametophytic phase cannot be inferred from culture results, as the whole temperature range permitting growth and reproduction was not investigated. However, if the highest temperature $\left(28^{\circ} \mathrm{C}\right)$ permitting vegetative growth and maturation of the gametophyte were near the limit, this would position the "southern growth and reproduction boundary" of the macrothallus-phase near a $30^{\circ} \mathrm{C}$ winter temperature. This suggests that the gametophyte of $A$. purpuriferum might flourish throughout the tropical belt, particularly so in deeper water $(15-30 \mathrm{~m})$ along oceanic coasts. Apparently it is restricted to warm temperate waters by the blocking of tetrasporogenesis at temperatures above $17^{\circ} \mathrm{C}$.

The "northern growth and reproduction boundary" of the gametophyte can be expected near a point where, during a period of at least one month, temperature arises above $17^{\circ}$ in summer, that is near the $17^{\circ} \mathrm{C}$ summer isotherm. If, in some summers, temperature remains too low, the species can survive as microthallus.

The lethal boundaries of both phases have not been experimentally tested. Especially the lethal boundaries of the perennial tetrasporophyte are important as absolute distribution boundaries. The "northern lethal boundary" of the microthallus must be near a winter temperature below $8^{\circ} \mathrm{C}$, the lowest temperature allowing growth and vegetative multiplication. Assuming that this boundary is near the $5{ }^{\circ} \mathrm{C}$ winter isotherm, this would allow occurrence of the microthallus along the coasts of the British Isles and on offshore reefs of the Carolinas, and not in N.E. America and on inshore coasts of the Carolinas. Crustose rhodophytes resembling the tetrasporophyte of Acrosymphyton and known as Hymenoclonium serpens are indeed known from the British Isles (CortelBreeman, 1975) but have probably partly been confused with Hymenoclonium-like tetrasporophytes of Bonnemaisonia asparagoides.

The highest experimental temperature to which the tetrasporophyte has been subjected is $20^{\circ} \mathrm{C}$, at which good growth is possible (but not tetrasporogenesis). If the tetrasporophyte could grow at the same high temperatures as the gametophyte $\left(28^{\circ} \mathrm{C}\right)$, it could be expected to grow in the tropical belt where it could maintain itself by vegetative multiplication.

In the hatched area of Fig. 29 A. purpuriferum is able to complete its life history; this area is clasped between the $17^{\circ} \mathrm{C}$ winter isotherm (the southern boundary of tetrasporogenesis and consequently the initiation of gametophytes) and the $17^{\circ} \mathrm{C}$ summer isotherm (the northern boundary for maturation of the gametophyte). The available distribution data are compatible with this area. However, A. purpuriferum is a comparatively rare species which has possibly been overlooked in other parts of its geographic range.

Tetrasporophytes can theoretically be expected far to the north of the $17^{\circ} \mathrm{C}$ summer 
isotherm (Fig. 29, stippled area). The occurrence of Hymenoclonium serpens in Brittany and the British Isles is compatible with this expectation (but confusion with tetrasporophytes of other rhodophytes is possible).

Tetrasporophytes can also be expected to the south of the $17^{\circ} \mathrm{C}$ winter isotherm (Fig. 24, stippled area).

Actually, to the south of the $17^{\circ} \mathrm{C}$ winter isotherm the Caribbean species Acrosymphyton caribaeum occurs (Taylor, 1952, 1960) (Fig. 29). This species differs from $A$. purpuriferum only in minor details of the carpogonial and auxiliary cellbranches, which details seem to be covered by the ranges of these characters in $A$. purpuriferum. This suggests that $A$. caribaeum and $A$, purpuriferum are conspecific. Tetrasporogenesis in the Caribbean populations can be expected to be initiated at higher temperatures than in the Banyuls populations. This would be by no means unusual, as comparable temperature ecotypes are now known for various other algal species (Scytosiphon lomentaria, Dumontia contorta, Rhodochorton purpureum).

If this is correct, $A$. purpuriferum belongs to the amphiatlantic tropical-to-temperate distribution group with a northeastern extension ( $C l$. coelothrix type).

\section{The Arctic distribution group \\ Clathromorphum circumscriptum}

The crustose coralline $C$. circumscriptum treated as an example comprises isomorphic tetrasporophyte and gametophyte generations in its life history; but reproduction takes place mostly by means of asexual bispores which are formed in bisporangial conceptacula.

The influence of combinations of temperature, light intensity, and daylength on the formation of bisporangia has been experimentally investigated by Adey (1973). Although it is difficult to disentangle in his experiments the influence of the three different factors, his results suggest that photoperiods of more than $12 \mathrm{hrs} /$ day and temperatures higher than $5^{\circ} \mathrm{C}$ block bisporogenesis (the formation of abortive conceptacula is less strictly blocked). Perhaps relatively high daily light doses, rather than photoperiod, block bisporogenesis. When these experimental data are applied to field conditions (a few m deep water) in Eastern Maine, bisporogenesis seems to be restricted there to the period December-March (Fig. 30), which roughly agrees with field data.

\section{CLATHROMORPHUM CIRCUMSCRIPTUM}

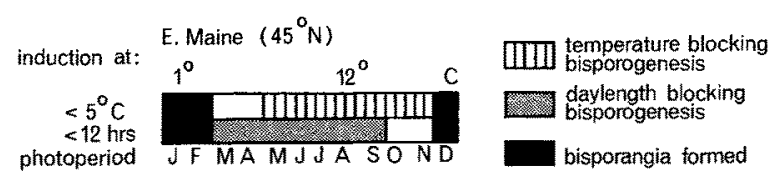

Fig. 30. Clathromorphum circumscriptum. Model of the seasonal reproductive cycle in E. Maine, by applying culture results to conditions in E. Maine (Adey, 1970, 1973)

Other experiments (Adey, 1970) indicate that $C$. circumscriptum shows good growth at temperatures between $0{ }^{\circ} \mathrm{C}$ and $17^{\circ} \mathrm{C}(700 \mathrm{~lx}, 14 \mathrm{~h}$ light/day $)$, but at $20^{\circ} \mathrm{C}$ growth stops. 
A positive photosynthetic effort is possible between $0^{\circ}$ and $20^{\circ} \mathrm{C}$. The compensation point varies from c. $30 \mathrm{~lx}$ at $0^{\circ} \mathrm{C}$ to $500 \mathrm{~lx}$ at $20^{\circ} \mathrm{C}$. Apparently in cold Arctic water a positive photosynthetic effort is possible at very low light intensities; this accords with the deep occurrence of this species in the Arctic (this is shown by many other benthic algae in the Arctic).

\section{Phytogeographic boundaries in the North Atlantic}

The "southern reproduction boundary" of Clathromorphum circumscriptum can be expected near a point where, during about 1-2 months in most winters, temperature drops below $5{ }^{\circ} \mathrm{C}$. This corresponds approximately with a mean February temperature of $4{ }^{\circ} \mathrm{C}$. The actual southern boundary is situated near the $3^{\circ} \mathrm{C}$ winter isotherm (Fig. 31).

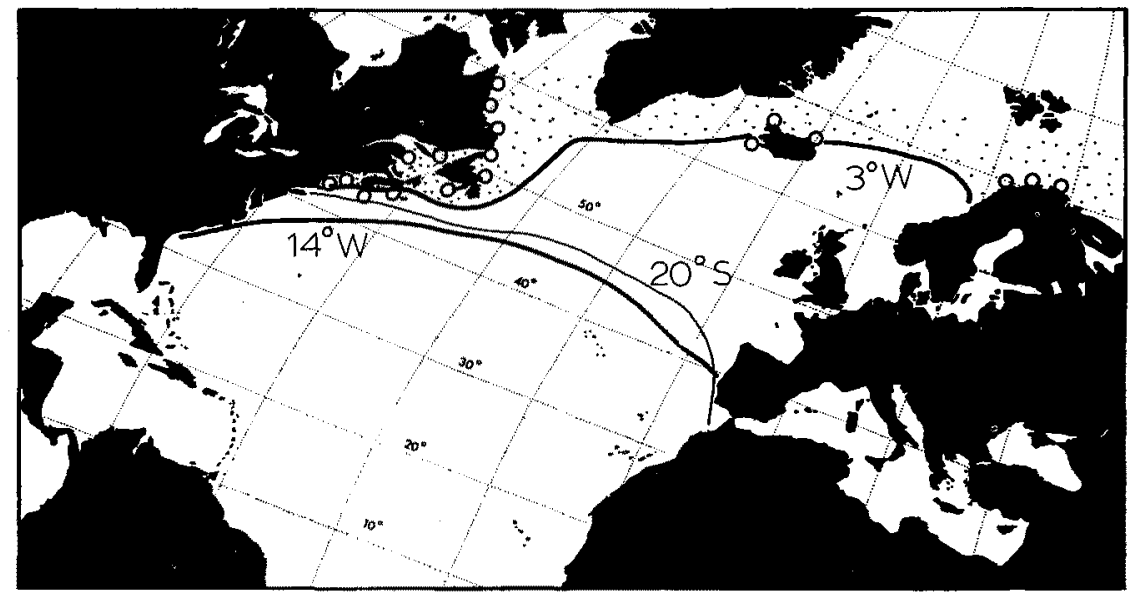

Fig. 31. Clathromorphum circumscriptum. Distribution in the North Atlantic Ocean (based on Adey, 1973)

The "southern growth boundary" can be expected near a point where, during a period of 1-2 months in each winter, temperature drops below $17^{\circ} \mathrm{C}$. This would correspond with a mean maximum February temperature of $\mathrm{c} .16^{\circ} \mathrm{C}$, and a mean February temperature of around $14^{\circ} \mathrm{C}$. Apparently the species remains far to the north of this boundary.

The "southern lethal boundary" has not been experimentally tested, but it can be expected at a temperature somewhat above $20^{\circ} \mathrm{C}$. This would correspond with about the $20^{\circ} \mathrm{C}$ summer isotherm, which is near the southernmost point of occurrence in N.E. America of this species.

Phytogeographic boundary in the North Atlantic and North Pacific

Also in the North Pacific the southern boundary is the "southern reproductive boundary" which closely follows the $3^{\circ} \mathrm{C}$ winter isotherm (see also Adey et al., 1976). In N.E. America, but still more so in Japan, the "southern reproduction boundary" and the "southern lethal boundary" almost coincide. In Japan, the "southern lethal boundary" is, 


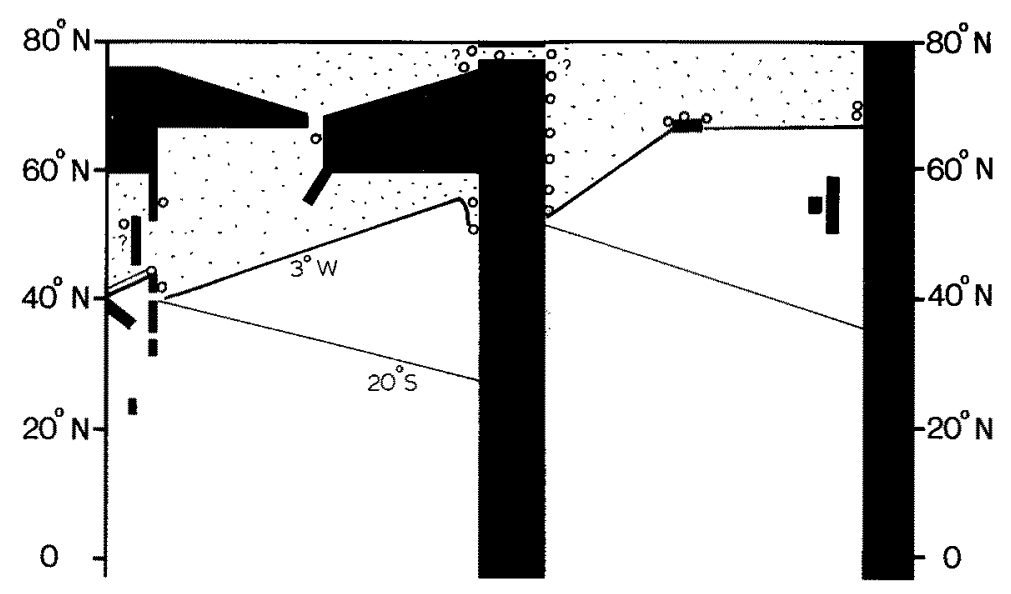

Fig. 32. Clathromorphum circumscriptum. Distribution in the North Atlantic and the North Pacific Oceans. Based on Adey, 1973, and on Adey et al. 1976; Hawkes et al., 1978; Lee, 1980 (O?: probably included in C. compactum); Vozžinskaja, 1964 (O?: probably included in Phymatolithon compactum)

in the Japan Sea, even situated somewhat to the north of the "southern reproduction boundary" and probably functions there as the real phytogeographic boundary (Fig. 32).

\section{DISCUSSION}

\section{Distribution groups}

The present paper reviews experimental evidence in support of seven out of ten geographic distribution groups of benthic marine algae previously distinguished in the North Atlantic Ocean on the basis of distribution data only. This evidence is also in agreement with experimental data reviewed in another recent paper (van den Hoek, 1982).

Three distribution groups consist of stenothermous species with a difference of $18-22^{\circ} \mathrm{C}$ between minimum and maximum lethal temperatures (expressed as highest and lowest mean monthly values), and of $5-12{ }^{\circ} \mathrm{C}$ between minimum and maximum temperatures (mean monthly values) allowing growth and/or reproduction. These groups are the "tropical Western Atlantic group" (group 6) (for which no experimental evidence is available); the "warm temperate Mediterranean-Atlantic group" (group 9); and the "Arctic group" (group 10). These three groups consist of species endemic to the corresponding regions. Especially the first two groups are extremely rich in species, as are corresponding distribution groups from the Pacific Ocean, namely the "tropical Western Pacific group", and the "warm-temperate Californian group".

The numerous species contained in group 9 (the warm-temperate MediterraneanAtlantic group) and the "warm-temperate Californian group" inhabit the eastern coasts of the Atlantic and North Pacific Oceans which are characterized by small annual temperature fluctuations (with a difference of $2-6{ }^{\circ} \mathrm{C}$ to $6-10^{\circ} \mathrm{C}$ between mean February 
and August temperatures, and up to $16^{\circ} \mathrm{C}$ difference between extreme values). These species are probably unfit for life on the western coasts of both oceans where annual temperature fluctuations occur of c. $20^{\circ} \mathrm{C}$ or more.

The large numbers of species endemic to the temperate coasts of the southern hemisphere probably have the same temperature requirements as group 9 , as these coasts are also characterized by small annual temperature fluctuations (c. $5^{\circ} \mathrm{C}$ between highest and lowest mean monthly values, and $10^{\circ} \mathrm{C}$ between extreme values).

It is likely that the species endemic to Antarctica have temperature responses comparable to those of the stenothermous Arctic species.

The remaining seven distribution groups $(1,2,3,4,5,7,8)$ consist of comparatively eurythermous species with the capacity to bridge a difference of more than $20^{\circ} \mathrm{C}$ between the minimum and maximum lethal temperatures (expressed as mean monthly values; the extreme difference is up to $35^{\circ} \mathrm{C}$ ). Although these eurythermous species are potentially capable of having wide geographic ranges those of distribution group 8 , the "North East American temperate group" and the corresponding "Japanese temperate group" are restricted to N.E. American coasts and Japanese (and adjacent) coasts, respectively. Only very few species are known to belong to this group in N.E. America. Polysiphonia harveyi (this work) is an example, whereas Japanese coasts are probably inhabited by hundreds of endemic species belonging to this distribution group. It is likely that the adverse nature of the vast sediment coasts in E. America between $30^{\circ} \mathrm{N}$ and $45^{\circ} \mathrm{N}$ is responsible for this striking difference. These coasts are also likely to have acted as barriers to latitudinal displacements of the benthic macroalgal flora during the glaciations, thus causing their impoverishment (van den Hoek, 1975, 1982).

Despite their capacity to bridge wide temperature spans and their potential capacity to inhabit many other temperate coasts, the numerous endemic Japanese species are restricted to Japanese and adjacent coasts. This points to a lack of capacity for long distance dispersal in these algae. Several Japanese endemics which have been accidentally introduced elsewhere appear to have spread indeed over wide latitudinal spans. Examples are Sargassum muticum (van den Hoek, 1982) and Bonnemaisonia hamifera (this work). The temperature-daylength regulation of this latter species is apparently adapted to conditions in Japan; elsewhere (in N.W. America, N.E. America and Europe) the life history makes the impression of having been disrupted; and the species, to maintain itself predominantly in the form of the tetrasporophyte, uses the capacity of this phase for vegetative multiplication.

Sargassum muticum, on the other hand, has a normal reproduction on the coasts of N.W. America and Europe, where it has been introduced (see van den Hoek, 1982, for further references).

The species of distribution groups $1,2,3,4,5$ and 7 can bridge wide temperature spans (more than $20^{\circ} \mathrm{C}$ difference between highest and lowest mean monthly values) and have wide geographic distributions. Many of them have amphiatlantic, amphipacific and part of them even amphiequatorial distributions. An interesting question is whether these species are originally endemic to the N.W. Pacific or N.W. Atlantic, and have succeeded to disperse to other coasts subsequently. One would consequently expect these species to have effective means of long distance dispersal, and this in contrast to species of distribution group 8 . 


\section{Phytogeographic boundaries}

The ten distribution groups discussed in this paper were primarily distinguished on the basis of distribution data (Figs 1-4). For each amphiatlantic species it seemed possible to approximate the northern boundary with either a summer isotherm (corresponding with a "northern growth and reproduction boundary") or with a winter isotherm (corresponding with a "northern lethal boundary"). In a similar way, it seemed possible to approximate the southern boundary with either a winter isotherm (corresponding with a "southern growth and reproduction boundary") or a summer isotherm (corresponding with a "southern lethal boundary").

Actually, a large proportion of investigated boundaries, particularly of southern boundaries appeared to be of a composite nature (Table 2), and corresponded with temperatures limiting reproduction (sometimes growth) along N.E. Atlantic shores and with lethal temperatures along N.W. Atlantic shores.

Most northern boundaries, however, are growth and/or reproduction boundaries on both sides of the N. Atlantic Ocean.

The large majority of investigated boundaries on the N.E. Atlantic shores are growth and reproduction boundaries, and only comparatively few are lethal boundaries. This is apparently related to the small annual temperature fluctuations along the N.E. Atlantic coasts. However, distribution group 9 (the warm-temperate Mediterranean-Atlantic group) contains possibly many species with a "northern lethal boundary" of $0^{\circ}$ to $5{ }^{\circ} \mathrm{C}$, restricting it to Europe (as in Saccorhiza polyschides, cf. van den Hoek, 1982). This remains to be investigated.

Apparently, distribution data alone may give useful suggestions about the nature of phytogeographic boundaries, but they may quite easily lead to incorrect conclusions. Experimental checks are necessary, as boundaries are often of a composite nature.

Consequently, the available evidence does not support the distinction between an amphiatlantic temperate group "with a southern boundary near a summer isotherm" (group 4) and an amphiatlantic temperate group "with a southern boundary near a winter isotherm" (group 5).

The phytogeographic boundaries of a species are determined by the temperature responses of the boundary populations. Ideally, therefore, these temperature responses should be checked for boundary populations and several populations in the intervening part of the geographic range. For none of the species considered in the present discussion are such complete sets of data available. For comparatively few species (Dumontia contorta, Scytosiphon lomentaria, Rhodochorton purpureum) were temperature-daylength respones investigated of populations from various points of these species' geographic areas. These three species appeared to have various temperature-daylength ecotypes. The southern boundaries could be explained by the temperature responses of investigated populations which were nearest to these boundaries. Possibly the lethal temperatures are less subject to ecotypic variation than temperatures limiting growth or reproduction. For instance, Dumontia contorta populations from the Isle of Man, the Grevelingen (S.W. Netherlands) and Roscoff differed in temperatures allowing initiation of macrothalli from microthalli, but not in the lethal temperature $\left(26^{\circ} \mathrm{C}\right)$ of the microthalli (Rietema, 1982, in prep.; van den Hoek, 1982). However, the upper lethal temperature of full-grown Laminaria saccharina sporophytes was c. $17^{\circ} \mathrm{C}$ for sporophy- 
tes from the Isle of Man, and more than $17^{\circ} \mathrm{C}$ for sporophytes from Helgoland (Lüning, 1975). Tropical Dictyota dichotoma from Puerto Rico seems to have a higher lethal temperature than a temperate population from Roscoff, Brittany (Biebl, 1959, 1962; this work).

For most species given in Table 1, however, the temperature responses of material from only one station are known. Nonetheless it was possible to use these to explain these species' geographic distribution, and this suggests that possible ecotypes do not differ much in their temperature responses. However, a population of Sphacelaria rigidula was investigated not far from the northern boundary of this species' vast tropical-to-temperate area, and this population may consequently have temperature responses typical for a boundary population. The same is true for the investigated populations of Gracilaria foliifera, Polysiphonia ferulacea, and Centroceras clavulatum (van den Hoek, 1982; this study).

Most species with wide distributions in the North Atlantic and the North Pacific Oceans, and some also in the southern hemisphere, are bounded throughout their geographic ranges by approximately the same temperature boundaries. Examples are Dictyota dichotoma (Fig. 6); Rhodochorton purpureum (Fig. 11); Nemalion helminthoides (Fig. 14); Punctaria latifolia (Fig. 22); Clathromorphum circumscriptum (Fig. 27); and Centroceras clavulatum, Sphacelaria rigidula, Laminaria saccharina, Scytosiphon lomentaria, Petalonia fascia, Macrocystis pyrifera (van den Hoek, 1982). This suggests that these species have the same genotypic range of temperature and daylength adaptation throughout their vast, and in some cases even disjunct, geographic areas. Notable exceptions are Dumontia contorta (van den Hoek, 1982, Fig. 16) and Chondrus crispus (Fig. 16) which occur in both the North Pacific and the North Atlantic Oceans, but are restricted to the N.W. Pacific coasts. One possible explanation is that these N.W. Pacific populations are bounded by much lower temperatures, limiting reproduction, than the N. Atlantic populations. Another explanation is that the records of these species from the N.W. Pacific are based upon misidentifications. This is apparently the case for Chondrus crispus, according to J. McLachlan (pers. comm.).

\section{Taxonomic problems}

One needs for the delineation of geographic areas, of course, taxonomically reliable records. Species belonging to critical groups which are in need of taxonomic revision are apparently less suitable for the present type of discussions. For instance, Callithamnion byssoides Arnott \& Harv. in Hook. seems to belong to the amphiatlantic tropical-totemperate distribution group on the basis of distribution data, and to be bounded to the North by the $15^{\circ} \mathrm{C}$ summer isotherm (which can be explained as a "northern growth and reproduction boundary") (Edwards, 1971; Kapraun, 1978b). However, the gonimoblast depicted by Edwards (1969) is uncharacteristic of $C$. byssoides (Rueness \& Rueness, 1980 ) so that it is likely that American and European samples identified as $C$. byssoides belong to more than one species. Comparable uncertainties exist with regard to Polysiphonia, Ceramium, Enteromorpha, Ulva, etc. The examples belonging to Polysiphonia and treated in the present paper are thought to be sufficiently characteristic to preclude much confusion.

The taxonomy of the genus Laminaria (cf. Table. 2) is presently in a state of flux. In 
Table 2. Nature of the northern and southern geographic boundaries of marine benthic algae in the North Atlantic Ocean. "Borrowed from van den Hoek (1982); other species treated in this work. **Estimates entirely based on distribution data (culture data lacking)

\begin{tabular}{|c|c|c|c|c|c|}
\hline \multirow[t]{2}{*}{ Northern boundaries } & \multirow[b]{2}{*}{$\begin{array}{l}\text { Distribution } \\
\text { group No. }\end{array}$} & \multicolumn{2}{|c|}{ W. side N. Atlantic } & \multicolumn{2}{|c|}{ E. side $\mathbf{N}$. Atlantic } \\
\hline & & $\begin{array}{c}\text { lethal } \\
\text { boundary } \\
\text { (winter } \\
\text { isotherm) }\end{array}$ & $\begin{array}{c}\text { reproduc- } \\
\text { tion/growth } \\
\text { boundary } \\
\text { (summer } \\
\text { isotherm) }\end{array}$ & $\begin{array}{c}\text { lethal } \\
\text { boundary } \\
\text { (winter } \\
\text { isotherm) }\end{array}$ & $\begin{array}{l}\text { reproduc- } \\
\text { tion/growth } \\
\text { boundary } \\
\text { (summer } \\
\text { isotherm) }\end{array}$ \\
\hline Dictyota dichotoma & 1 & $2^{\circ} \mathrm{C}$ & & & $13^{\circ} \mathrm{C}^{* *}$ \\
\hline Gracilaria foliifera* & 1 & $8^{\circ} \mathrm{C}$ & & $8^{\circ} \mathrm{C}$ & \\
\hline Polysiphonia ferulacea & 1 & $10^{\circ} \mathrm{C}$ & & & $20^{\circ} \mathrm{C}$ \\
\hline Centroceras clavulatum & 1 & $12^{\circ} \mathrm{C}$ & & & $20^{\circ} \mathrm{C}$ \\
\hline Hypnea musciformis & 2 & & $19^{\circ} \mathrm{C}^{* *}$ & & $19^{\circ} \mathrm{C}^{* *}$ \\
\hline Sphacelaria rigidula (furcigera)* & 3 & & $12^{\circ} \mathrm{C}$ & & $12^{\circ} \mathrm{C}$ \\
\hline Polysiphonia denudata & 3 & & $16^{\circ} \mathrm{C}$ & & $16^{\circ} \mathrm{C}$ \\
\hline Callithamnion hookeri & 4 & & $10^{\circ} \mathrm{C}$ & & $10^{\circ} \mathrm{C}$ \\
\hline Nemalion helminthoides & 4 & & $12^{\circ} \mathrm{C}$ & & $12^{\circ} \mathrm{C}$ \\
\hline Dumontia contorta* & 4 & & $5^{\circ} \mathrm{C}$ & & $5^{\circ} \mathrm{C}^{* *}$ \\
\hline Chondrus crispus & 4 & & $7^{\circ} \mathrm{C}$ & & $7^{\circ} \mathrm{C}$ \\
\hline Monostroma grevillei & 4 & & $3^{\circ} \mathrm{C}$ & & $3^{\circ} \mathrm{C}$ \\
\hline Punctaria latifolia & 5 & & $4^{\circ} \mathrm{C}^{* *}$ & & $4^{\circ} \mathrm{C}^{* *}$ \\
\hline Scytosiphon lomentaria & 5 & & $0^{\circ} \mathrm{C}^{* *}$ & & $0^{\circ} \mathrm{C}^{* *}$ \\
\hline Petalonia fascia & 5 & & $0^{\circ} \mathrm{C}^{* *}$ & & $0^{\circ} \mathrm{C}^{* *}$ \\
\hline Gracilaria tikvahiae* & 7 & & $15^{\circ} \mathrm{C}$ & & \\
\hline Polysiphonia harveyi & 8 & & $12^{\circ} \mathrm{C}$ & & \\
\hline Saccorbiza polyschides* & 9 & & & $4^{\circ} \mathrm{C}$ & \\
\hline Laminaria hyperborea* & 9 & & & $2^{\circ} \mathrm{C}^{* *}$ & or $5^{\circ} \mathrm{C}^{* *}$ \\
\hline Acrosymphyton purpuriferum & 9 & & & & $17^{\circ} \mathrm{C}$ \\
\hline \multirow[t]{2}{*}{ Southern boundaries } & & \multicolumn{2}{|c|}{ W. side N. Atlantic } & \multicolumn{2}{|c|}{ E. side N. Atlantic } \\
\hline & $\begin{array}{c}\text { Distribution } \\
\text { group No. }\end{array}$ & $\begin{array}{c}\text { lethal } \\
\text { boundary } \\
\text { (summer } \\
\text { isotherm) }\end{array}$ & $\begin{array}{l}\text { reproduc- } \\
\text { tion/growth } \\
\text { boundary } \\
\text { (winter } \\
\text { isotherm) }\end{array}$ & $\begin{array}{c}\text { lethal } \\
\text { boundary } \\
\text { (summer } \\
\text { isotherm) }\end{array}$ & $\begin{array}{c}\text { reproduc- } \\
\text { tion/growth } \\
\text { boundary } \\
\text { (winter } \\
\text { isotherm) }\end{array}$ \\
\hline Rhodochorton purpureum & 4 & $20^{\circ} \mathrm{C}$ & & $20^{\circ} \mathrm{C}$ & \\
\hline Callithamnion hookeri & 4 & $24^{\circ} \mathrm{C}$ & & $24^{\circ} \mathrm{C}$ & \\
\hline Nemalion helminthoides & 4 & $25^{\circ} \mathrm{C}$ & & & $16^{\circ} \mathrm{C}$ \\
\hline Dumontia contorta* & 4 & $21^{\circ} \mathrm{C}$ & & & $12^{\circ} \mathrm{C}$ \\
\hline Chondrus crispus & 4 & $24^{\circ} \mathrm{C}$ & & & $17^{\circ} \mathrm{C}$ \\
\hline Laminaria saccharina* & $4 \rightarrow 10$ & $19^{\circ} \mathrm{C}$ & & $19^{\circ} \mathrm{C}$ & \\
\hline L. digitata* & $4 \rightarrow 10$ & $19^{\circ} \mathrm{C}$ & & & $10^{\circ} \mathrm{C}$ \\
\hline Desmarestia aculeata & $4 \rightarrow 10$ & $20^{\circ} \mathrm{C}^{* *}$ & & & $12^{\circ} \mathrm{C}$ \\
\hline D. viridis & $4 \rightarrow 10$ & $25^{\circ} \mathrm{C}^{* *}$ & & & $10^{\circ} \mathrm{C}$ \\
\hline Monostroma grevillei & 4 & $20^{\circ} \mathrm{C}^{* *}$ & & & $12^{\circ} \mathrm{C}$ \\
\hline Punctaria latifolia & 5 & $27^{\circ} \mathrm{C}$ & & & $14^{\circ} \mathrm{C}$ \\
\hline Scytosiphon lomentaria* & 5 & & $17^{\circ} \mathrm{C}$ & & $17^{\circ} \mathrm{C}$ \\
\hline Petalonia fascia* & 5 & & $17^{\circ} \mathrm{C} * *$ & & $17^{\circ} \mathrm{C}^{* *}$ \\
\hline Polysiphonia harveyi & 8 & & $19^{\circ} \mathrm{C}$ & & \\
\hline Saccorhiza polyschides* & 9 & & & & $15^{\circ} \mathrm{C}$ \\
\hline Laminaria hyperborea* & 9 & & & $19^{\circ} \mathrm{C}$ & \\
\hline Acrosymphyton purpuriferum & 9 & & & & $17^{\circ} \mathrm{C}$ \\
\hline Clathromorphum circumscriptum & 10 & & $3^{\circ} \mathrm{C}$ & & $3^{\circ} \mathrm{C}$ \\
\hline Saccorhiza dermatodea* & 10 & $15^{\circ} \mathrm{C}$ & & & $4^{\circ} \mathrm{C}$ \\
\hline Sphacelaria arctica* & 10 & $16^{\circ} \mathrm{C}^{* *}$ & & & $4^{\circ} \mathrm{C}$ \\
\hline
\end{tabular}


the North Atlantic, L. hyperborea and L. ochroleuca are quite distinct. In the S. Atlantic Ocean (S. Africa, Tristan da Cunha) this latter species is difficult to differentiate from $L$. pallida and the digitate species $L$. brasiliensis Joly \& Oliveira Filho (1967) from deep water (70-95 m) near Rio de Janeiro, Brazil. L. digitata and L. saccharina are presently conceived as polymorphic species in the $\mathrm{N}$. Atlantic, and their relation to N. Pacific entities needs revision (for a review, see Kain, 1979). L. saccharina from the N. Pacific seems to be somewhat different from $N$. Atlantic $L$. saccharina (Kain, 1979). Its relation to the simple $L$. abyssalis Joly \& Oliveira Filho (1967) from deep water in Brazil needs clarification.

\section{Species and genera with amphiequatorial distributions}

Particularly the eurythermous temperate distribution groups contain species with a world wide amphiequatorial distribution. Examples are Rhodochorton purpureum (Fig. 11), Nemalion helminthoides (Fig. 14), and Ulvaria obscura (Fig. 33) in the amphi-

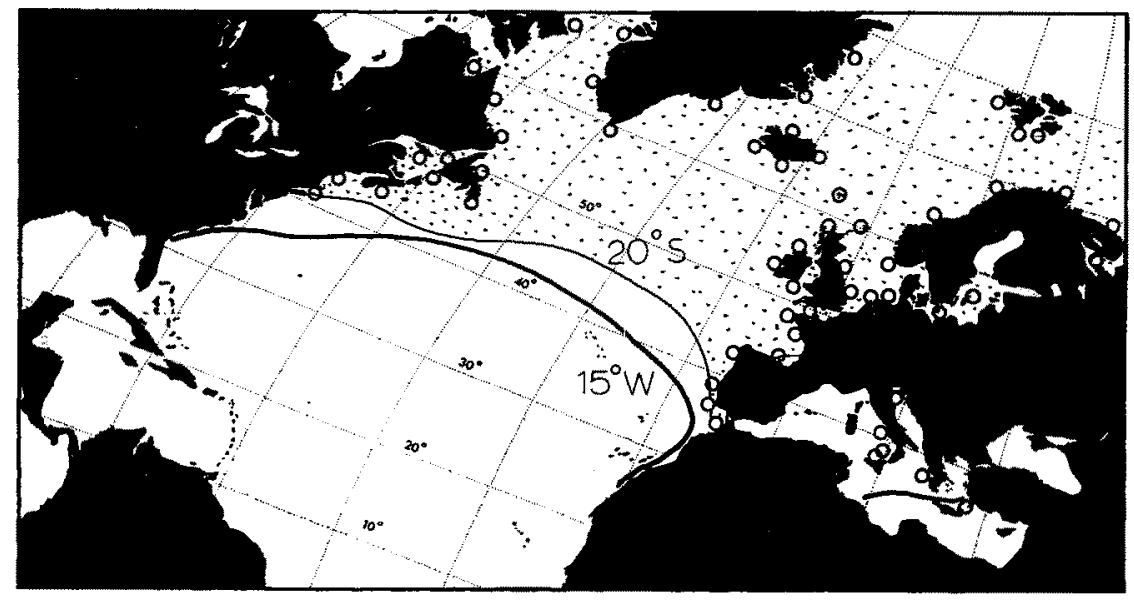

Fig. 33. Ulvaria obscura. Distribution in the North Atlantic Ocean. The bounding isotherms are entirely inferred from distribution data and are consequently provisional. The $20^{\circ} \mathrm{C}$ summer isotherm $\left(20^{\circ} \mathrm{S}\right)$ is thought to be the southern lethal boundary. U. obscura consequently belongs to the amphiatlantic distribution group of the Cl. rupestris type (group 4). The $15^{\circ} \mathrm{C}$ winter isotherm $\left(15^{\circ} \mathrm{W}\right)$ represents the southern reproduction boundary, which does not function as actual boundary

atlantic temperate distribution group of the Cl. rupestris type (group 4) (Table 3). The bounding isotherms of $U$. obscura are entirely based on distribution data and should consequently be considered as provisional. Scytosiphon lomentaria, Petalonia fascia and Punctaria latifolia (Fig. 22) are examples in the amphiatlantic temperate distribution group of the $\mathrm{Cl}$. albida type (group 5). Macrocystis pyrifera, Laminaria ochroleuca/ pallida, and Desmarestia ligulata (Figs 34,35 ) are comparatively stenothermous and function as examples in the warm-temperate distribution groups (group 9). In the N. Atlantic Ocean, D. ligulata's temperature requirements probably make this species unfit for life on the W. Atlantic shores; in the N. Pacific, however, these temperature requirements allow $D$. ligulata to inhabit just a narrow latitudinal zone along Japanese 
and adjacent shores. As the bounding isotherms of $D$. ligulata are entirely based on distribution data, they should be considered as provisional.

These amphiequatorial distributions can be explained by assuming exchange of the species concerned between the hemispheres during glacial temperature drops. The tropical east coasts of the Atlantic Ocean and Pacific Ocean are the most likely points of such an exchange, as the tropical belts are here and were during the glaciations much narrower than along the west coasts of these oceans. Moreover, the present near-equator coasts on the east sides of both oceans are characterized by upwelling. This upwelling causes in equatorial W. Africa local temperature drops to about $20^{\circ} \mathrm{C}$ in August, while maximum temperatures in March may be $28^{\circ} \mathrm{C}$ (mean monthly temperatures) (Lawson, 1966; John et al., 1977; Corcoran \& Mahnken, 1969).

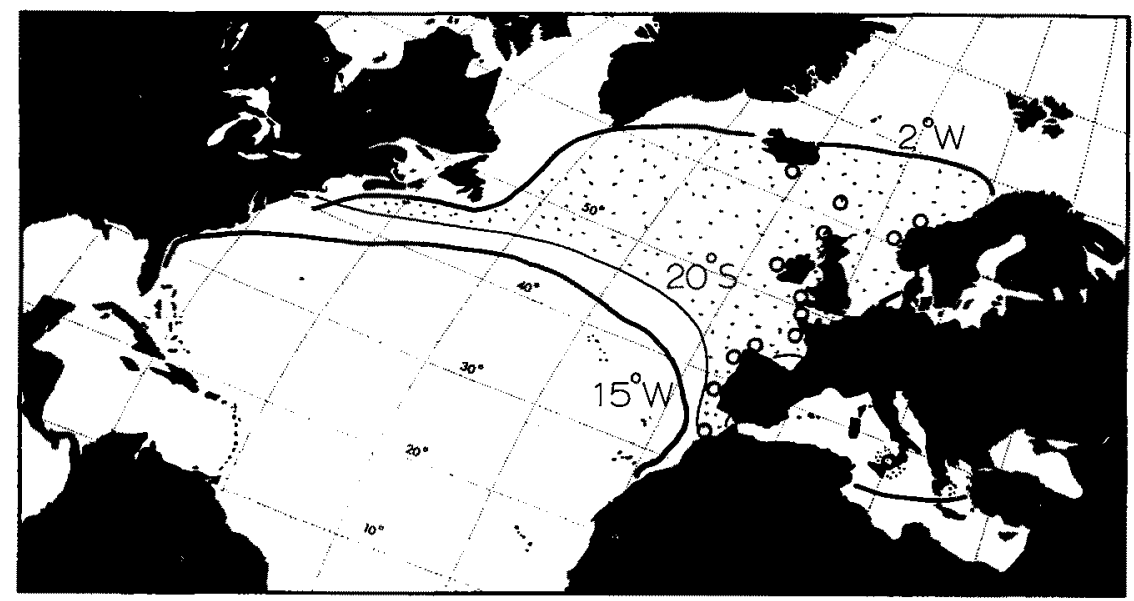

Fig. 34. Desmarestia ligulata. Distribution in the North Atlantic Ocean. The bounding isotherms are entirely inferred from distribution data and are consequently provisional. The $2^{\circ} \mathrm{C}$ winter isotherm $\left(2^{\circ} \mathrm{W}\right)$ is the northern lethal boundary, the $20^{\circ} \mathrm{C}$ summer isotherm $\left(20^{\circ} \mathrm{S}\right)$ the southern lethal boundary. The $15^{\circ} \mathrm{C}$ winter isotherm $\left(15^{\circ} \mathrm{W}\right)$ represents the southern reproduction boundary, which does not function as an actual boundary. D. ligulata apparently belongs to the "warm temperate Mediterranean-Atlantic distribution group" and is unable to grow in N.E. America, where it is not able to bridge the wide annual temperature fluctuations

As we know the equatorwards temperature requirements of these amphiequatorial species, we can estimate the glacial temperature drop necessary to create a passage for temperate species across the equator. This passage was probably a narrow inshore zone of intense upwelling related to the intensified circulation of the ocean gyres during the glaciations (McIntyre et al., 1976). Table 3 summarizes the temperature requirements of the above mentioned amphiequatorial species at their present equatorwards boundaries, the present corresponding equatorial temperatures of the surface water in the Pacific and Atlantic Oceans, and the estimated glacial temperature drops necessary for creating the passage at the surface. In the East Pacific Ocean the minimum equatorial surface temperature should have dropped c. $10-13^{\circ} \mathrm{C}$ and in the East Atlantic Ocean c. $8-11^{\circ} \mathrm{C}$, to allow reproduction of the species (or formation of macrothalli from microthalli in Scytosiphon lomentaria, Petalonia fascia and Punctaria latifolia). The maximum equato- 


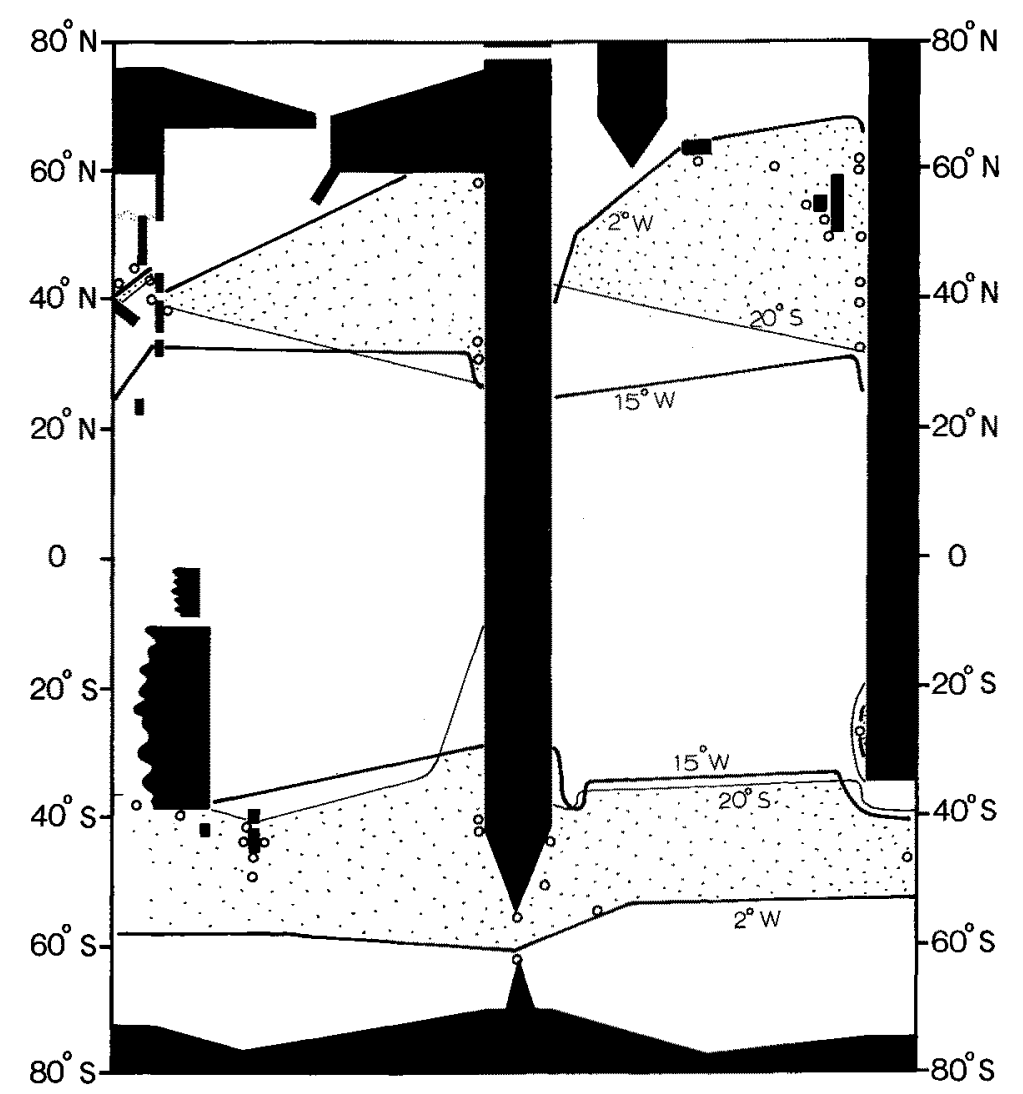

Fig. 35. Desmarestia ligulata. Distribution in the Atlantic and Pacific Oceans. In the N. Pacific Ocean, temperature requirements of $D$. ligulata allow this species to occupy just a very narrow latitudinal belt along Japanese and adjacent shores

rial temperatures should have dropped c. 0 to $10^{\circ} \mathrm{C}$ (depending on species) to allow survival (all temperatures as mean monthly values).

Such glacial temperature drops of c. $10^{\circ} \mathrm{C}$ of the surface water along eastern equatorial coasts of the Atlantic and Pacific Oceans, and the much earlier pliocene closing of the isthmus of Panama, could also explain the widely disjunct distribution of many strictly tropical species, such as Cladophora catenata $(=C$. fuliginosa), Neomeris dumetosa, Valonia aegagropila, Dictyosphaeria cavernosa, Caulerpa mexicana, Udotea flabellum and Halimeda simulans. These species are restricted to the western sides of the tropical Atlantic and Pacific Oceans possibly as a result of extinction by low glacial temperatures (down to $15^{\circ} \mathrm{C}$, mean monthly value) along the eastern coasts of the tropical Atlantic and Pacific Oceans (van den Hoek, 1982).

However, these hypothetical paleotemperatures are considerably lower than those in a recent reconstruction of paleotemperatures of the oceans during the last glaciation $(18,000 \mathrm{y}$ b.p.; McIntyre et al, 1976; Frakes, 1979). In this reconstruction, low glacial temperatures are assumed to have extended much farther towards the equator than at present along the eastern coasts of the Pacific and Atlantic Oceans, and this in conjunc- 


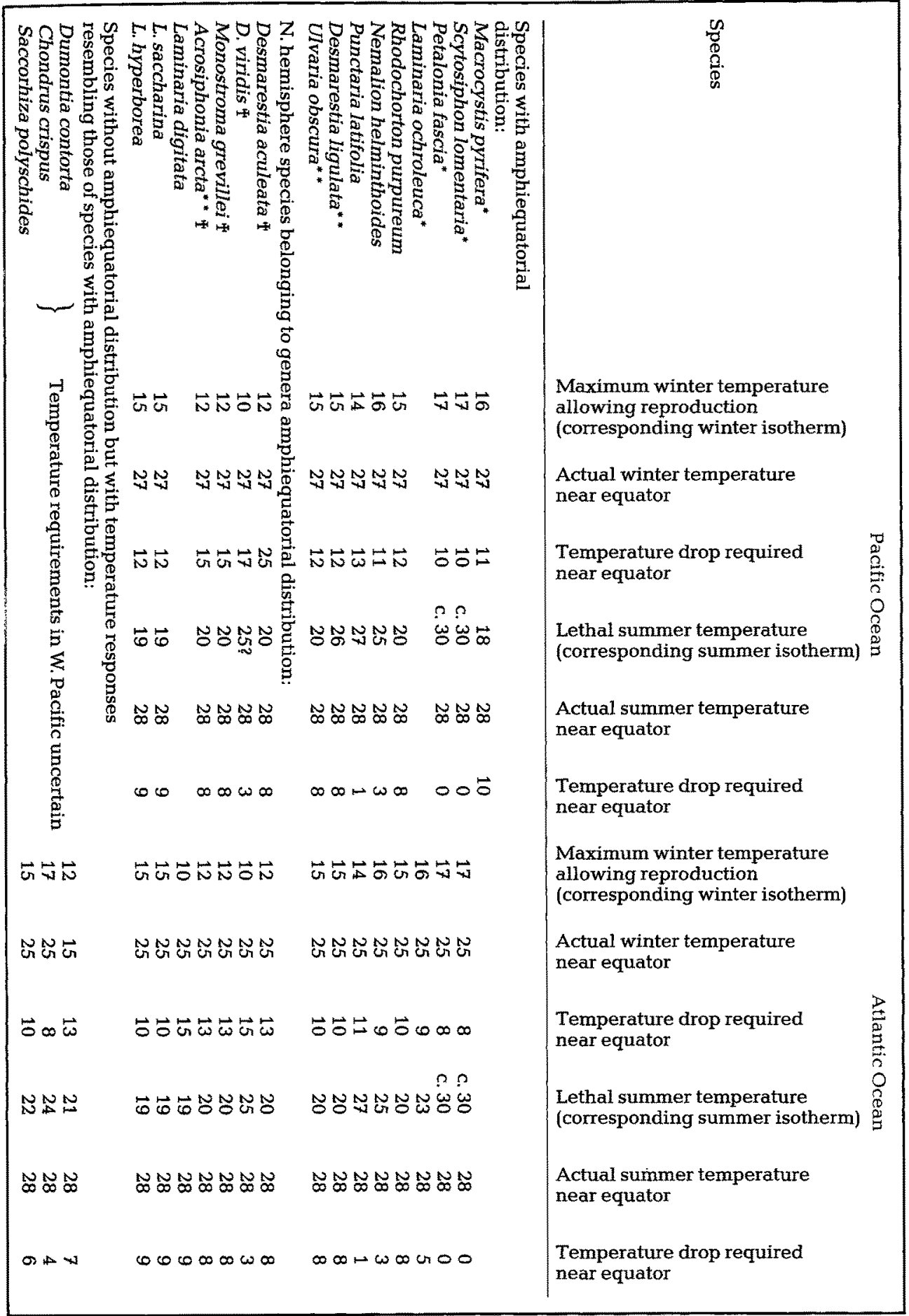


tion with increased upwelling and advection of cool water, but the temperatures of the equatorial surface waters are assumed to have had values comparable to the present ones. These paleotemperatures were inferred mainly from assemblages of microfossils (foraminifera, coccoliths, radiolaria) entombed in 247 sediment cores taken from the world's seabed.

In a recent review (Sarnthein et al., 1981) the glacial paleotemperatures of the equatorial surface waters along the African W. coast (18,000 b.p.) are assumed to have differed from present temperatures only by $1-2{ }^{\circ} \mathrm{C}$ in February but by $2-8{ }^{\circ} \mathrm{C}$ in August. A lowering of $2{ }^{\circ} \mathrm{C}$ in February and of $8^{\circ} \mathrm{C}$ in August (as compared with present temperature conditions) would have allowed passage of the shallow water species Scytosiphon lomentaria, Petalonia fascia, Punctaria latifolia and (nearly) of Nemalion helminthoides; but not of Macrocystis pyrifera, Laminaria ochroleuca, Rhodochorton purpureum, Desmarestia ligulata and Ulvaria obscura (cf. Table 2).

The passage, across the equator, of these latter five shade tolerant species can be explained by assuming that they used the still lower temperatures of deep euphotic layers in highly transparant waters in the glacial equatorial regions. Temperatures in the lower reaches of deep euphotic layers may be considerably lower than these of the surface water. For instance, along Brazilian coasts $\left(21-23^{\circ} \mathrm{S}\right)$ Laminaria abyssalis (related to $L$. saccharina) and $L$. braziliensis (related to $L$. ochroleuca/pallida) are restricted to deep water $(70-95 \mathrm{~m})$ where temperature fluctuates between $16-20^{\circ} \mathrm{C}$; the surface temperatures vary here between 20 and $25^{\circ} \mathrm{C}$ (mean monthly values) (Joly \& Oliveira Filho, 1967; Kain, 1979; Oliveira Filho, 1976).

At present, the waters along the equatorial African W. coast are highly turbid; the lower limit of the benthic algae at Ghana has been recorded at $30 \mathrm{~m}$ (John et al., 1977). If the euphotic zone were c. $100 \mathrm{~m}$ deep instead, the prevailing temperature conditions at that depth $\left(15-17^{\circ} \mathrm{C}\right.$, cf. Postel, 1966) would allow reproduction and survival of most species listed in Table 2. Possibly, 18,000 years before present, the equatorial waters along W. Africa were more transparent than they are now, as the arid belt had shifted to the south and the freshwater discharge of the rivers, such as the Niger was low (Sarnthein et al., 1981). Moreover, the c. $100 \mathrm{~m}$ lower glacial sea level probably brought submerged offshore seamounds within the reach of this deep euphotic layer, which could thus function as stepping stones for the passage of temperate benthic algae across the equator.

From the point of view of low transparency, the E. Pacific shores seem to offer a better pathway than E. Atlantic shores as there are no great rivers and uninterrupted flat sediment shores. Actually our knowledge of the deep water floras of E. Atlantic and E. Pacific equatorial shores (continental shores as well as island shores) is very limited; these floras should be explored for possible temperate elements. In this respect the occurrence, in the deep water flora of the Galapagos Islands, of endemic species of the temperate algal genera Eisenia (E. galapagensis) and Desmarestia (D. tropica) is relevant (Taylor, 1945). The genus Eisenia (Phaeophyceae, Laminariales) is distributed along N.W. and N.E. Pacific shores and its nearest known point of occurrence is southern Baja California (where the narrowly related Eisenia arborea occurs in upwelling areas). The genus Desmarestia is widely distributed in the temperate zones of both hemispheres.

Here the enigmatic records of Desmarestia aculeata and D. ligulata dredged from 
deep water (50-70 m) off Puerto Rico should be mentioned (Diaz-Piferrer, 1969). According to the data in the present paper, $D$. aculeata and $D$. ligulata need $12^{\circ} \mathrm{C}$ or less and $15^{\circ} \mathrm{C}$ or less, respectively, for their reproduction, and both $20^{\circ} \mathrm{C}$ or less for survival (as mean monthly temperatures; Table 3). It is hardly likely that such low temperatures occur near Puerto Rico at 50-70 m depth. It is, however, equally unlikely that these specimens have drifted to Puerto Rico $\left(18^{\circ} \mathrm{N}\right)$ from their nearest point of occurrence $\left(40^{\circ} \mathrm{N}\right.$ in N.E. America for D. aculeata, and $35^{\circ} \mathrm{N}$ in N.W. Africa for D. ligulata).

The combination of $2-8{ }^{\circ} \mathrm{C}$ lowered glacial surface temperatures and an increase in thickness of the euphotic layer cannot explain the absence of stenothermous tropical algal species along the East Atlantic shores by extinction, as these species can apparently reproduce and survive in surface waters which are $2-8^{\circ} \mathrm{C}$ cooler than they are at present along equatorial African coasts. Possibly intermittent short catastrophic cold spells lowering the surface temperature to $10-15^{\circ} \mathrm{C}$ in the course of the numerous glaciations and which cannot be traced in the microfossil record were responsible for a gradual extinction of stenothermous tropical species.

An alternative explanation for the amphiequatorial distribution of the above temperate species (Table 3 ) is that these species once had warm water ecotypes capable of crossing the equator using only slightly lower temperatures than the present temperatures. This is unlikely in view of the world wide similar temperature requirements of these species at their present boundaries. Moreover, this could not explain the disjunct distribution of strictly tropical species.

Table 3 also lists seven species belonging to genera with an amphiequatorial distribution. Four of these species (Desmarestia aculeata, D. viridis, Monostroma grevillei, Acrosiphonia arcta) have also been recorded from cool temperate waters in the southern hemisphere, but they have probably been confused with other species in these genera (Papenfuß, 1964). For passage of the equator, these four species would have required a temperature drop of c. $15^{\circ} \mathrm{C}$ in order to allow reproduction (c. $10^{\circ} \mathrm{C}$ in the lowest part of a deep euphotic layer and c. $5^{\circ} \mathrm{C}$ more than the species with amphiequatorial distribution). The temperature drop required to allow survival of maximum temperatures would have been $3-8^{\circ} \mathrm{C}$ near the surface, and up to $3^{\circ} \mathrm{C}$ in the lowest part of a deep euphotic layer which is within the range of the nine amphiequatorial species. This suggests that ancestor species in Desmarestia, Monostroma and Acrosiphonia having about the same temperature requirements as the present nine amphiequatorial species, were exchanged between both hemispheres during early temperature drops, and that the isolated populations in the temperate zones of both hemispheres developed lower limiting temperatures allowing reproduction, but not or hardly lower lethal temperatures.

The temperature requirements of Laminaria saccharina and L. hyperborea are within the ranges of the nine amphiequatorial species, and consequently exchange could be expected. Actually, the occurrence of Laminaria species in the South Atlantic Ocean is in favour of this hypothesis. The taxonomic relationship between the digitate species L. pallida (S. Africa, Tristan da Cunha), L. schinzii (S. Africa) and L. braziliensis (a Brazilian deep water species) on the one hand, and the N. Atlantic L. hyperborea and $L$. ochroleuca on the other hand needs further investigation, as does the relationship between $L$. saccharina and the simple Brazilian deep water species $L$. abyssalis (Kain, 1979; Joly \& Oliveira Filho, 1967). These species probably represent isolated relictual 
populations of glacial immigrants from the North Atlantic which use local cool water conditions (upwelling in S. Africa; cool [16-20 ${ }^{\circ} \mathrm{C}$, cf. Oliveira Filho, 1976] deep water in Brazil [21-23 ${ }^{\circ}$ ] comparable to the cool deep water harbouring $L$. ochroleuca in the Mediterranean).

The numerous climatic pulsations accompanying the gradually steepening temperature gradient between equator and poles in the course of the tertiary and the pleistocene (Frakes, 1979) are probably an important agent of repeated exchange of cool water species across the equator during cooler periods and the subsequent isolation of populations during warmer periods. Comparatively recent exchanges are probably reflected by amphiequatorial species, and comparatively old exchanges by amphiequatorial genera. The closure of the isthmus of Panama in pliocene and the subsequent glaciations causing the contraction of the tropical belt probably resulted in the widely disjunct distribution of apparently very old tropical species which are now restricted to the western sides of the tropical Pacific and Atlantic Oceans, and which were extinguished along the eastern sides of these oceans.

These climatic pulsations necessitated the repeated latitudinal displacements of the benthic algal floras, causing, on the one hand, the extinction of species lacking escape routes along uninterrupted rocky coast lines or series of stepping stones (islands, rocky outcrops on sediment coasts), and thus creating at the same time new room for renewed speciation. Also the glacial sea-level changes causing alternating closure and opening of sea straits (such as the Bering Straits) may have contributed to isolation and subsequent extinction or speciation. Lateral seas such as the Mediterranean, the Gulf of Mexico and the Gulf of California, may have contributed to speciation by the repeated isolation of populations during climatic changes.

It is an attractive hypothesis that Japanese and adjacent shores are the main centre of speciation of eurythermous temperate species with wide distributions, which succeeded in dispersing to N.E. Pacific shores, and towards the Atlantic Ocean through the Canadian Arctic, during relatively warm interglacial periods; and finally towards the southern hemisphere across the equator during glacial temperature drops.

Acknowledgements. I am grateful to Dr. A. M. Breeman and Mr. B. Hoeksema for permitting me to use for this study not yet published results on the life history of Rhodochorton purpureum, Dr. W. Sarnthein and his colleagues for permission to consult a preprint of their paper, and to Dr. E. C. Pielou for putting at my disposal an unpublished distribution list of algal species along American coasts. I appreciate the critical and inspiring comments of Dr. K. Lüning. Dr. A. M. Breeman, and the discussions with Dr. H. Rietema and Dr. G. J. Boekschoten. I would like to thank Mrs. S. WalburghSchmidt for typing the manuscript and Mr. H. C. Holleman for helping with the literature.

\section{LITERATURE CITED}

Abbott, I. A. \& Hollenberg, G. J., 1976. Marine algae of California. Stanford Univ. Press, Stanford, Calif., $827 \mathrm{pp}$.

Adey, W. H., 1970. The effects of light and temperature on growth rates in boreal-subarctic crustose corallines. - J. Phycol. 6, 269-276.

Adey, W. H., 1973. Temperature control of reproduction and productivity in a subarctic coralline alga. - Phycologia 12, 111-118.

Adey, W. H., Masaki, T. \& Akioka, H., 1976. The distribution of crustose corallines in Eastern Hokkaido and the biogeographic relationships of the flora. - Bull. Fac. Fish. Hokkaido Univ. 26, 303-313. 
Ardré, F., 1970. Contribution à l'étude des algues marines du Portugal. - Port. Acta biol. (B) 10, $1-420$.

Ardré, F, 1971. Contribution à l'étude des algues marines du Portugal. - Bull. Cent. Etud. Rech. scient. Biarritz $8,359-574$.

Baardseth, E., 1941. The marine algae of Tristan da Cunha. - Results Norw. scient. Exped. Tristan da Cunha 9, 1-174.

Biebl, R., 1959. Temperatur- und osmotische Resistenz von Meeresalgen der bretonischen Küste. Protoplasma 50, 217-242.

Biebl, R., 1962. Temperaturresistenz tropischer Meeresalgen. - Botanica mar, 6, 241-253.

Bird, C. J., Edelstein, T. \& McLachlan, J., 1977a. Studies in Gracilaria. Experimental observations on growth and reproduction in Pomquet Harbour, Nova Scotia. - Naturaliste can. 104, $245-255$.

Bird, C. J., Edelstein, T. \& McLachlan, J., 1977b. Studies on Gracilaria. Occurrence in Atlantic Canada, with particular reference to Pomquet Harbour, Nova Scotia. - Naturaliste can. 104, $257-266$.

Bird, C. J., Chen, L. C.-M. \& McLachlan, J., 1978. Effects of temperature, light and salinity on growth in culture of Chondrus crispus, Furcellaria Iumbricalis, Gracilaria tikvahiae (Gigartinales, Rhodophyta) and Fucus serratus (Fucales, Phaeophyta). - Botanica mar, 22, 521-527.

Boudouresque, C. F. \& Perret, M., 1977. Inventaire de la flore marine de la Corse (Méditerranée) . Biblthca Phycol. 25, 1-170.

Brauner, J. F, 1975. Seasonality of epiphytic algae on Zostera marina at Beaufort, North Carolina. Nova Hedwigia 26, 125-133.

Breeman, A. M., 1979. The life history and its environmental regulation in the subtidal red alga Acrosymphyton purpuriferum (J. Ag.) Sjöst. Thesis, Univ. Groningen, $141 \mathrm{pp}$.

Chamberlain, Y. M., 1965. Marine algae of Gough Island. - Bull. Br. Mus. nat. Hist. 3, 175-232.

Chapman, A. R. O.\& Burrows, E. M., 1970. Experimental investigations into the controlling effects of light conditions on the development and growth of Desmarestia aculeata (L) Lamour. Phycologia 9, 103-108.

Chapman, A. R. O. \& Burrows, E. M., 1971. Field and culture studies of Desmarestia aculeata (L.) Lamour. - Phycologia 10, 63-76.

Chapman, V. J., 1969. The marine algae of New Zealand. Part III. Rhodophyceae. Cramer, Lehre, $113 \mathrm{pp}$.

Chen, L. C.-M., Edelstein, T., Bird, C. \& Yabu, H., 1978. A culture and cytological study of the life history of Nemalion helminthoides (Rhodophyta, Nemaliales). - Proc. Nova Scotian Inst. Sci. 28, 191-199.

Chen, L. C.-M., Edelstein, T. \& McLachlan, J., 1969. Bonnemaisonia hamifera Hariot in nature and in culture. $-J$. Phycol. 5, 211-220.

Chen, L. C.-M. \& McLachlan, J., 1972. The life history of Chondrus crispus in culture. - Can. J. Bot. $50,1055-1060$.

Chiang, Y.-M., 1972. Keys to the genera of marine algae of Taiwan. - Taiwania 17, 8-13.

Chiang, Y.-M., 1973. Notes on marine algae of Taiwan. - Taiwania 18, 13-17.

Chihara, M., 1961. Life cycle of Bonnemaisoniaceous algae in Japan. - Sci. Rep. Tokyo Kyoiku Daig. (Sect. 13) 10, 121-153.

Chihara, M., 1962. Life cycle of the Bonnemaisoniaceous algae in Japan (2). - Sci. Rep. Tokyo Kyoiku Daig, (B). 11, 27-55.

Chihara, M. \& Yoshizaki, M., 1970. Marine algal flora and communities along the coast of Tsushima Islands. - Mem. nat. Sci. Mus. Tokyo 3, 143-158.

Christensen, T. \& Thomson, H. A., 1974. Algefortegnelse. Oversigt over udbredelsen of Danske saltog brakvandsarter fraset ikke-plantiske kiselalger. - Universitets Bogladen, Naturfagsbogladen, København, $35 \mathrm{pp}$.

Clayton, M. \& Ducker, S. C., 1970. The life history of Punctaria latifolia Greville (Phaeophyta) in Southern Australia. - Aust. J. Bot. 18, 293-300.

Corcoran, E. F. \& Mahnken, C. V. W., 1969. Productivity of the tropical Atlantic Ocean. In: Proceedings of the symposium on the oceanography and fisheries resources of the tropical Atlantic. UNESCO, Paris, 57-67.

Cortel-Breeman, A. M., 1975. The life history of Acrosymphyton purpuriferum (J. Ag.) Sjöst. 
(Rhodophyceae, Cryptonemiales). Isolation of tetrasporophytes. With some remarks on the tetrasporophyte of Bonnemaisonia asparagoides (Woodw.) C. Ag. (Nemalionales). - Acta bot. neerl. 24, 111-127.

Cortel-Breeman, A. M. \& Hoek, C. van den, 1970. Life history studies on Rhodophyceae. I. Acrosymphyton purpuriferum (J. Ag.) Kyl. - Acta bot. neerl. 19, 265-284.

Cortel-Breeman, A. M. \& Hoopen, A. ten, 1978. The short day response in Acrosymphyton purpuriferum (J. Ag.) Sjöst. (Rhodophyceae, Cryptonemiales). - Phycologia 17, 125-132.

Dangeard, P., 1963. Sur le développement de Punctaria latifolia Greville récolté dans le Bassin d'Arcachon. - Botaniste 46, 205-224.

Dangeard, P., 1966. Sur le Punctaria crouanï (Thuret) Bornet récolté à Soulac, et sur son développement. - Botaniste 49, 157-167.

Dawes, C. J., 1974. Marine algae of the west coast of Florida. Univ. Miami Press, Coral Gables, Fla, $201 \mathrm{pp}$.

Dawson, E. Y., 1946. A guide to the literature and distribution of the marine algae of the Pacific Coast of North America. - Mem. S. Calif: Acad. Sci. 3 (1), 1-134.

Day, J. H., 1969. A guide to marine life on South African shores. Balkema, Cape Town, 300 pp.

Diannellidis, T., Haritonidis, S. \& Tsekos, I., 1977. Contribution à l'étude des algues benthiques de quelques régions de l'île de Rhodos, Grèce. - Botanica mar. 20, 205-226.

Diaz-Piferrer, M., 1969. Distribution of the marine benthic flora of the Caribbean Sea. - Caribb. J. Sci. 9, 151-178.

Dixon, P. S. \& Irvine, L. M., 1977. Seaweeds of the British Isles. Vol. I. Rhodophyta. Part 1. Introduction, Nemaliales, Gigartinales. Br. Mus. nat. Hist., London, $252 \mathrm{pp}$.

Earle, S. A., 1969. Phaeophyta of the Eastern Gulf of Mexico. - Phycologia 7, 71-254.

Edelstein, T., 1964. On the sublittoral algae of the Haifa Bay area. - Vie Milieu 15, 177-212.

Edelstein, T., 1977. Studies on Gracilaria sp.: experiments on inocula incubated under greenhouse conditions. - J. exp. mar. Biol. Ecol. 30, 249-259.

Edelstein, T. \& McLachlan, J., 1966. Investigations of the marine algae of Nova Scotia. I. Winter flora of the Atlantic coast. - Can. J. Bot. 44, 1035-1055.

Edelstein, T. \& McLachlan, J., 1968. Investigations of the marine algae of Nova Scotia. V. Additional species new or rare to Nova Scotia. - Can. J. Bot. 46, 993-1003.

Edelstein, T., Bird, C. J. \& McLachlan, J., 1976. Studies on Gracilaria 2. Growth under greenhouse conditions. - Can. J. Bot. 54, 2275-2290.

Edelstein, T., Chen, L. C.-M. \& McLachlan, J., 1970. Investigations of the marine algae of Nova Scotia VIII. The flora of Digby Neck Peninsula, Bay of Fundy. - Can. J. Bot. 48,621-629.

Edelstein, T., Craigie, J. C. \& McLachlan, J., 1969. Preliminary survey of the sublittoral flora of Halifax County. - J. Fish. Res. Bd Can. 26, 2703-2713.

Edwards, P., 1969. The life-history of Callithamnion byssoides in culture, - J. Phycol. 5, $266-268$.

Edwards, $P_{*}, 1970$ a. Mlustrated guide to seaweeds and sea grasses in the vicinity of Port Aransas, Texas. - Contr. mar. Sci. (Suppl.). 15, 1-128.

Edwards, P., 1970b. Field and cultural observations on the growth and reproduction of Polysiphonia denudata from Texas. - Br. phycol. J. 5, 145-153.

Edwards, P., 1971. Effects of light intensity, daylength, and temperature on growth and reproduction of Callithamnion byssoides. In: Contributions in phycology. Ed. by B. C. Parker \& R. M. Brown. Allen Press, Lawrence, Kansas, 163-173.

Edwards, P., 1979. A cultural assessment of the distribution of Callithamnion hookeri (Dillw.) S. F. Gray (Rhodophyta, Ceramiales) in nature. - Phycologia 18, 251-263.

Feldmann, J., 1939. Les algues marines de la Côte des Albères IV. - Revue algol. 11, $247-330$.

Feldmann, J., 1941. Les algues marines de la Côte des Albères IV. - Revue algol. 12, 77-100.

Feldmann, J., 1942. Les algues marines de la Côte des Albères IV. - Trav. algol. 1, $29-118$.

Feldmann, J., 1954. Inventaire de la flore marine de Roscoff. - Trav. Stat. biol. Roscoff (Suppl.) 6, $1-152$.

Feldmann-Mazoyer, G., 1940. Recherches sur les céramiales de la Méditerranée Occidentale. Minerva, Alger, 510 pp.

Fortes, M. D. \& Lüning, K., 1980. Growth rates of North Sea macroalgae in relation to temperature, irradiance and photoperiod. - Helgoländer Meeresunters. 34, 15-29.

Frakes, L. A., 1979. Climates throughout geologic time. Elsevier, Amsterdam, 310 pp. 
Fries, L., 1967. The tetrasporophyte of Nemalion multifidum (Weber et Mohr) J. Ag. - Svensk bot. Tidskr. 61, 457-462.

Fries, L., 1969. The sporophyte of Nemalion multifidum (Weber et Mohr) J. Ag. found on the Swedish West Coast. - Svensk bot. Tidskr. 61, 457-462.

Funahashi, S., 1966. Marine algae from Vladivostok and its vicinity. - Bull. Jap. Soc. Phycol. 14, 127-145.

Funahashi, S., 1967. Marine algae in the vicinity of Noto marine laboratory. - A. Rep. Noto mar. Lab. $7,15-36$.

Funahashi, S., 1974. Distribution of marine algae in the Japan Sea, with reference to the phytogeographical positions of Vladivostok and Noto Peninsula districts. - J. Fac. Sci. Hokkaido Univ. (Ser. 5) 10,1-31.

Funk, G., 1955. Beiträge zur Kenntnis der Meeresalgen von Neapel. - Pubbl. Staz. zool. Napoli 25 , (Suppl.) 1-178.

Furnari, G. \& Scammacca, B., 1973. Ricerche floristiche sulle alghe marine della Sicilia orientale. Nuovo contributo. - Boll. Accad. Gioenia Sci. nat. Catania (Ser. 4) 11 (7-8), 1-22.

Furnari, G., Scammacca, B., Cormacci, M. \& Battiato, M., 1977. Zonazione della vegetazione sommersa dell' Isola Lachea (Catania). - Atti Congr. Soc. ital. Biol. mar. 9, 245-257.

Giaccone, G., 1969. Raccolte di fitobenthos sulla banchina continentale Italiana. - Giorn. Bot. Ital. $103,485-514$.

Giaccone, G., 1978. Revisione della flora marina del mare Adriatico. Parco marino di Miramare, stazione di controllo, Trieste, $118 \mathrm{pp}$.

Giaccone, G. \& Longo, L. R., 1976. Revisione della Flora dello Stretto di Messina (note storiche, bionomiche e corologiche). - Mem. Biol. mar. Oceanogr. 6, 69-122.

Hamel, G., 1930. Floridées de France 6. - Revue algol. 5, 61-109.

Hamel, G., 1931-39. Phéophycées de France. Wolf, Paris, 432 pp.

Haritonidis, S. \& Tsekos, I., 1974. A survey of the marine algae of Thassos and Mytilene Islands, Greece. - Botanica mar. 17, 30-39.

Hartog, C. den, 1959. The epilithic algal communities occurring along the coast of the Netherlands. - Wentia 1, $241 \mathrm{pp}$.

Hawkes, M., Tanner, C. E. \& Lebednik, P. A., 1978. The benthic marine algae of northern British Columbia. - Syesis 11, 81-115.

Hirose, H. \& Kajimura, M., 1973. Additional list of marine algae of Oki Islands. - Bull. Jap. Soc. Phycol. 21, 33-38.

Hoek, C. van den, 1963. Revision of the European species of Cladophora. Brill, Leiden, 248 pp. (Reprint: Koeltz, Königstein, 1976).

Hoek, C. van den, 1975. Phytogeographic provinces along the coasts of the northern Atlantic Ocean. - Phycologia 14, 317-330.

Hoek, C. van den, 1979. The phytogeography of Cladophora (Chlorophyceae) in the northern Atlantic Ocean, in comparison to that of other benthic algal species. - Helgoländer wiss. Meeresunters. 32, 374-393.

Hoek, C. van den, 1981. A taxonomic revision of the American species of Cladophora (Chlorophyceae) in the North Atlantic Ocean and their geographic distribution. - Verh. K. Akad. Wetensch. Amsterdam. (In press.)

Hoek, C. van den, 1982. Distribution groups of benthic marine algae in relation to the temperature regulation of their life histories. - Systematics Association Spec. Vol. (In press.)

Hoek, C. van den, Cortel-Breeman, A. M., Rietema, H. \& Wanders, J. B. W., 1972. L'interprétation des données obtenues, par des cultures unialgales, sur les cycles évolutifs des algues. Quelques exemples tirés des recherches conduites au laboratoire de Groningue. - Mém. Soc. bot. Fr. 1972, 45-66.

Hoek, C. van den \& Donze, M., 1967. Algal phytogeography of the European Atlantic coasts. Blumea 15, 63-89.

Humm, H. J., 1979. The marine algae of Virginia. - Spec. Pap. mar. Sci. 3, 1-263.

Hutchins, L.-W., 1947. The basis for temperature zonation in geographical distribution. - Ecol. Monogr. 17, 325-335.

Jaasund, E., 1965. Aspects of the marine algal vegetation of North Norway. - Bot. gothoburg. 4, $1-174$.

John, D. M., Liebermann, D. \& Liebermann, M., 1977. A quantitative study of the structure and 
dynamics of benthic subtidal algal vegetation in Ghana (tropical West Africa). - J. Ecol. 65, $497-521$.

Joly, A. B. \& Oliveira Filho, E. C. de, 1967. Two Brazilian Laminarias. - Publçoēs Inst. Pesq. Mar. 4, $1-13$

Jónsson, $H_{\text {. }}$ 1912. The botany of Iceland, I. The marine algal vegetation. Frimodt, Copenhagen, $186 \mathrm{pp}$.

Jónsson, S., 1962. Recherches sur des Cladophoracées marines (structure, reproduction, cycles comparées, conséquences systématiques). Thèse, Université de Paris, $230 \mathrm{pp}$.

Jónsson, S., 1968. Sur le cycle ontogénétique et chromosomique du Monostroma grevillei (Thur.) Wittr. de Roscoff. - C.r. hebd. Seánc. Acad. Sci., Paris, 267, 402-405.

Juett, L., Miller, C. J., Moore, S. J. \& Ford, E. S., 1976. Summer marine algae at Vero Beach, Florida. - Fla Scient. 39, 76-80.

Kain, J. M., 1979. A view of the genus Laminaria. - Oceanogr. mar. Biol. 17, 101-106.

Kapraun, D. F., 1977. The genus Polysiphonia in North Carolina, U.S.A. - Botanica mar. 20, 313-331.

Kapraun, D. F., 1978a. Field and cultural studies on selected North Carolina Polysiphonia species. Botanica mar. 21, 143-153.

Kapraun, D. F., 1978b. Field and culture studies on growth and reproduction of Callithamnion byssoides (Rhodophyta, Ceramiales) in North Carolina. - J. Phycol. 14, 21-24.

Kapraun, D. F., 1980. Floristic affinities of North Carolina inshore benthic marine algae. Phycologia 19, 245-252.

Knaggs, F. H., 1967. A review of the world distribution and ecology of Rhodochorton purpureum (Lightf.) Rosenvinge. - Nova Hedwigia 14, 549-570.

Koch, W., 1950. Entwicklungsgeschichtliche und physiologische Untersuchungen an Laboratoriumskulturen der Rotalge Trailiella intricata Batters (Bonnemaisoniaceae). - Arch. Mikrobiol. $14,635-660$.

Konno, K., 1973. On the marine algae from the coast of Oga Peninsula facing the Japan Sea. - Bull. Jap. Soc. Phycol. 21, 1-11.

Kornmann, P., 1962a. Die Entwicklung von Monostroma grevillei. - Helgoländer wiss. Meeresunters. $8,195-202$.

Kornmann, P., 1962b. Eine Revision der Gattung Acrosiphonia. - Helgoländer wiss. Meeresunters. $8,219-292$.

Kornmann, P., 1962c. Der Lebenszyklus von Desmarestia viridis. - Helgoländer wiss. Meeresunters. $8,287-292$.

Kornmann, P. \& Sahling, P.-H., 1977. Meeresalgen von Helgoland. - Helgoländer wiss. Meeresunters. 29, 1-289.

Kühnemann, O., 1972. Bosquejo fitogeografico de la vegetacion marina del litoral Argentino. Physis $31,117-142$.

Lawson, G. W., 1966. The littoral ecology of West Africa. - Oceanogr. mar. Biol. 4, 405-448.

Lawson, G. W., John, D. M. \& Price, J. H., 1975. The marine algal flora of Angola: its distribution and affinities. - Bot. J. Linn. Soc. 70, 307-324.

Lawson, G. W. \& John, D. M., 1977. The marine flora of the Cap Blanc Peninsula: its distribution and affinities. - Bot. J. Linn. Soc. 75, 99-118.

Lee, I. K. \& Kim, Y. H., 1977. A study on the marine algaeg in the Kwang Yang Bay 3. The marine algal flora. - Proc. Coll. nat. Sci. (Seoul) 2, 113-153.

Lee, R. K. S., 1973. General ecology of the Canadian Arctic benthic marine algae. Arctic. - J. Arctic Inst. N. Am. 26, 33-43.

Lee, R. K. S., 1980. A catalogue of the marine algae of the Canadian Arctic. - Publs. Bot. nat. Mus. nat. Sci. 9, 1-82.

Lee, Y. P. \& Lee, I. K., 1976. On the algal community in the intertidal belt of Jeju Island. 1. Algal community of spring season. - Korean J. Bot. 19, 111-118.

Levring, T., 1960. Contributions to the marine algal flora of Chile. - Lunds Univ. Årsskr. N.F. (Avd. 2) 56 (10), 1-85.

Levring, T., 1974. The marine algae of the Archipelago of Madeira. - Bolm Mus. munic. Funchal 28 (125), 5-111. 
Lindauer, V. W., Chapman, V. J. \& Aiken, M., 1961. The marine algae of New Zealand II: Phaeophyceae. - Nova Hedwigia 3, 129-350.

Lipkin, Y., 1972. Marine algae and seagrass flora of the Suez Canal. - Israel J. Zool. 21, 405-446. Lüning, K., 1980. Critical levels of light and temperature regulating the gametogenesis of three Laminaria species (Phaeophyceae). - J. Phycol. 16, 1-15.

Lüning, K, 1981a. Control of algal life-history by daylength and temperature. In: The shore environment. Ed. by J. H. Price, D. E. G. Irvine, W. F. Farnham. Acad. Press, New York, 915-945.

Lüning, K., 1981b. Photomorphogenesis of reproduction in marine macroalgae. - Ber. dt. bot. Ges. (In press.)

Makienko, V. F., 1975. Vodorosli-macrofity zaliva Vostok (Japanskoje Mor'e). - Biol. Morja 2, 45-57.

Martin, M. T., 1967. Observations on the life history of Nemalion helminthoides (Vell.) Batt. $-\mathrm{Br}$. phycol. Bull. 3,408.

Masuda, M. \& Umezaki, I., 1977. On the life history of Nemalion vermiculare Suringar (Rhodophyta) in culture. - Bull. Jap. Soc. Phycol. 25, $129-136$.

Mathieson, A. C., 1979. Vertical distribution and longevity of subtidal seaweeds in Northern New England, U.S.A. - Botanica mar. 30, 511-520.

May, D. de, John, D. M. \& Lawson, G. W., 1977. A contribution to the littoral ecology of Liberia. Botanica mar. 20, 41-46.

McIntyre, A. and 35 others (CLIMAP project members), 1976. The surface of the ice-age earth. Science, N.Y. 191, 1131-1137.

McLachlan, J., Chen, C.-M. \& Edelstein, T., 1969. Distribution and life history of Bonnemaisonia hamifera Hariot. - Proc. int. Seaweed Symp. 6, 245-249.

McLachlan, J. \& Edelstein, T, 1977. Life-history and culture of Gracilaria folitfera (Rhodophyta) from South Devon. - J. mar. biol. Ass. U.K. 57, 577-586.

Moura Baptista, L. R. de, 1977. Flora marinha de Torres, - Bolm Inst. Biociénc. Porto Alegre (Bot.) 37, $1-244$.

Müller, D. G., 1962. Über jahres- und lunarperiodische Erscheinungen bei einigen Braunalgen. Botanica mar. 4, 140-155.

Munda, I. M., 1977. The benthic algal vegetation of the island of Grimsey (Eyja fjarăarsýsla, North Iceland). - Bull. Res. Inst. Neđri Ás 28, 1-69.

Munda, I. M., 1978. Survey of the benthic algal vegetation of the Dýrafjördur, northwest Iceland. Nova Hedwigia 29, 281-403.

Munda, I. M., 1980. Contribution on the knowledge of the benthic algal vegetation of the Mýrar area (Faxaflói, southwest Iceland). - Bull. Res. Inst. Neări Ás 33, 1-48.

Nakaniwa, M., 1975. Marine algae along the coast of Ibaraki Prefecture. - Bull. Jap. Soc. Phycol. 23, 99-110.

Newton, L., 1931. A handbook of the British Seaweeds. Br. Mus, nat. Hist., London, 478 pp.

Nizamuddin, M., West, J. A. \& Menez, E. G., 1979. A list of marine algae from Libya. - Botanica mar. $22,465-476$.

Norton, T. A., 1977. Experiments on the factors influencing the geographical distributions of Saccorhiza polyschides and Saccorhiza dermatodea. - New Phytol. 78, 625-635.

Notoya, M., 1979. Life history of Campylaephora hypnaeoides. - Jap. J. Phycol, 27, 201-204.

Ogawa, H. \& Machida, M., 1976. Marine algae of the Oshika Peninsula. I. Chlorophyceae and Phaeophyceae. - Tohoku J. agric. Res. 27, 145-154.

Ohta, M. \& Kurogi, M., 1979. Rhodochorton purpureum (Lightf.) Rosenvinge. - Jap. J. Phycol. 27, $161-167$.

Oliveira Filho, E. C. de 1976 . Deep water marine algae from Espirito Santo State (Brazil). - Bolm Bot. Univ. S. Paulo 4, 73-80.

Oliveira Filho, E. C. de, 1977. Algas marinhas bentônicas do Brasil. Thesis, Univ. São Paulo, $407 \mathrm{pp}$.

Orris, P, K. \& Taylor, J. E, 1973. A floristic and ecological survey. The benthic macroalgae of Rehoboth Bay, Delaware. - Botanica mar. 16, 180-192.

Pankow, H., 1971. Algenflora der Ostsee I. Benthos. VEB Fischer, Jena, 419 pp.

PapenfuB, G. F, 1964. Catalogue and bibliography of Antarctic and Subantarctic benthic marine algae. - Antarct. Res. Ser. 1, 1-76. 
Pedersen, P. M., 1976. Marine benthic algae from southernmost Greenland. - Meddr Grønland 199 (3), 1-77.

Perez-Cirera, J. L., 1975. Catalogo floristico de las algas bentonicas de la Ria de Corme y Lage, NO. de España. - An. Inst. bot. A. J. Cavanillo 32, 5-87.

Postel, E., 1966. Répartition et abondance des thons dans l'Atlantique tropical. - Proc. Symp. Oceanography Fish. Res. trop. Atlant., Unesco, 109-146.

Price, J..H., John, D. M. \& Lawson, G. W., 1978. Seaweeds of the western coast of tropical Africa and adjacent islands: a critical assessment. II. Phaeophyta. - Bull. Br. Mus. nat. Hist. (Bot) 6r 87-182.

Rhodes, R. G., 1970. Seasonal occurrence of marine algae on an oyster reef in Burton's Bay, Virginia. - Chesapeake Sci. 11, 61-71.

Richardson, J. P., 1979. Overwintering of Dictyota dichotoma (Phaeophyceae) near its northern distribution limit on the east coast of North America. - J. Phycol. 15, 22-26.

Rietema, H. \& Hoek, C. van den, 1981. The life history of Desmotrichum undulatum (J. Ag.) Reinke (Phaeophyceae) and its regulation by temperature and light conditions. - Mar. Ecol. Progr. Ser. $4,321-335$.

Rietema, H. \& Klein, A. W. O., 1981. Environmental control of the life cycle of Dumontia contorta (Rhodophyta) kept in culture. - Mar. Ecol. Progr. Ser. 4, 23-29.

Rueness, J., 1977. Norsk Algeflora. Universitetsforlaget, Oslo, $266 \mathrm{pp}$.

Rueness, J. \& Rueness, M., 1980. Culture and field observations on Callithamnion bipinnatum and C. byssoides (Rhodophyta, Ceramiales) from Norway. - Sarsia 65, 29-34.

Santelices, B., 1980. Phytogeographic characterization of the temperate coast of Pacific South America. - Phycologia 19, 1-12.

Sarnthein, M., Thiede, J., Pflaumann, U., Erlenheuser, H., Fütterer, D., Koopmann, B., Lange, H. \& Seibold, H., 1981. Atmospheric and oceanic circulation patterns off N.W. Africa during the past 25 million years. In: The geology of the Northwest African Continental Margins. Ed. by U. von Rad, K. Hinz, M. Sarnthein \& E. Seibold. Springer, Berlin. (In press.)

Scagel, R. F., 1957. An annotated list of the marine algae of British Columbia and Northern Washington (including keys to genera). - Bull, natn. Mus. Can. 150, 1-289.

Scagel, R. F., 1966. Marine algae of British Columbia and Northern Washington, Part I: Chlorophyceae (green algae). - Bull. natn. Mus. Can. 207, 1-257.

Ščapova, T. F. \& Vozžinskaja, V. B., 1960. Vodorosli litorali zapadnogo poberežja Sachalina. Trudy Inst. Okeanologii 34, 123-146.

Schmidt, O. C., 1931. Die marine Vegetation der Azoren in ihren Grundzügen dargestellt. Biblthca bot. 102, 1-116.

Schneider, C. W., 1976. Spatial and temporal distributions of benthic marine algae on the continental shelf of the Carolinas. - Bull. mar. Sci. 26, 133-151.

Schneider, C. W., Suyemoto, M. M. \& Yarish, C., 1979. An annotated checklist of Connecticut seaweeds. - Bull. geol. nat. Hist. Surv., Connecticut Dept. Environ Prot. 108, 1-20.

Searles, R. B. \& Schneider, C. W., 1978. A checklist and bibliography of North Carolina seaweeds. Botanica mar. 21, 99-108.

Sears, J. R., 1971. Morphology, systematics and descriptive ecology of the sublittoral benthic marine algae of southern Cape Cod and adjacent islands. Thesis, Univ. Massachusetts. Univ, Microfilms Int., Ann Arbor, 293 pp.

Setchell, W. A. \& Gardner, N. L., 1919-20. The marine algae of the Pacific coast of North America. P. 1-3: Myxophyceae, Chlorophyceae, Melanophyceae. - Univ. Calif. Publs Bot. 8, 1-898.

Sève, M. A. de, Cardinal, A. \& Goldstein, M. E., 1979. Les algues marines benthiques des lles-de-laMadeleine (Québec). - Proc. Nova Scotian Inst. Sci. 29, 223-233.

Simpson, F. J. \& Shacklock, P. F, 1979. The cultivation of Chondrus crispus. Effect of temperature on growth and carrageenan production. - Botanica mar. 22, 295-298.

South, G. R., 1976. A checklist of marine algae of Eastern Canada-first revision. - J. mar. biol. Ass. U.K. $56,817-843$.

South, G. R. \& Hooper, R. C., 1980. A catalogue and atlas of the benthic marine algae of the Island of Newfoundland. - Mem. Univ. Newfoundland occ. Pap. Biol. 3, 1-136.

Stegenga, H., 1978. The life histories of Rhodochorton purpureum and Rhodochorton floridulum (Rhodophyta, Nemaliales) in culture. - Br. phycol, J. 13, 279-289. 
Stephenson, T. A. \& Stephenson, A., 1972. Life between tidemarks on rocky shores. Freeman, San Francisco, 425 pp.

Tanaka, T. \& Itono, H., 1972. The marine algae from the Island of Yanaguni II. - Mem. Fac. Fish. Kagoshima Univ. 21, 1-14.

Tatewaki, M., 1972. Life history and systematics in Monostroma. In; Contributions to the systematics of benthic marine algae of the North Pacific. Ed. by I. A. Abbott \& M. Kurogi. Jap. Soc. Phycol., Kobe, 1-15.

Taylor, W. R, 1945. Pacific marine algae of the Allan Hancock expeditions to the Galapagos Islands. - Allan Hancock Pacif. Exped. 12, 1-528.

Taylor, W. R., 1952. Reproduction of Acrosymphyton caribaeum. Pap. Mich. Acad. Sci. 36, 31-37.

Taylor, W. R., 1957. Marine algae of the northeastern coast of North America. Univ. Michigan Press, Ann Arbor, 509 pp.

Taylor, W. R., 1960. Marine algae of the eastern tropical and subtropical coasts of the Americas. Univ. Michigan Press, Ann Arbor, 870 pp.

Tokida, J., 1954. The marine algae of Southern Saghalien. - Mem. Fac. Fish. Hokkaido Univ. 2, $1-264$.

Tsekos, I. \& Haritonidis, S., 1977. A survey of the marine algae of the Ionian Islands, Greece. Botanica mar. 20, 47-65.

Tsuda, R. T. \& Wray, F. O., 1977, Bibliography of marine benthic algae in Micronesia. - Micronesica $13,85-120$.

Tveter-Gallagher, E., Mathieson, A. D. \& Cheney, D. P., 1980. Ecology and developmental morphology of male plants of Chondrus crispus (Gigartinales, Rhodophyta). - J. Phycol. 16, $257-264$.

Umezaki, I., 1967. The tetrasporophyte of Nemalion vermiculare Suringar. - Revue algol, 9, $19-24$.

Velasquez, G. T., Trono, G. C. \& Doty, M. S., 1975. Algal species reported from the Philippines. Philipp. J. Sci. 101, 115-169.

Velasquez, G. T. \& Lewmanomont, K., 1975. A checklist on the study of the benthic marine algae of Thailand. - Kasetsart Univ. Fish. Res. Bull. 8, 1-25.

Vielhaben, V., 1963. Zur Deutung des semilunaren Fortpflanzungszyklus von Dictyota dichotoma. Z. Bot. $51,156-173$.

Vince-Prue, D., 1975. Photoperiodism in plants. McGraw-Hill, Maidenhead, 444 pp.

Vozžinskaja, V. B., 1964. Makrofity morskich probrežij Sachalina. - Trudy Inst. Okeanol. 69, $330-440$.

Vozžinskaja, V. B., 1965. Morskije vodorosli zapadnogo poberežija Kamčatki. - Nov. Syst. Nizšich Rastenij 1965, 73-76.

West $t_{f}$ J. A., 1969. The life histories of Rhodochorton purpureum and $R$, tenue in culture. - J. Phycol. $5,12-21$.

West, J. A., 1970. A monoecious isolate of Rhodochorton purpureum. - J. Phycol. 6, 368-370.

West, J. A., 1972. Environmental regulation of the reproduction in Rhodochorton purpureum. In: Contribution to the systematics of the benthic marine algae of the North Pacific. Ed. by I. A. Abbott \& M. Kurogi. Jap. Soc. Phycol. Kobe, 213-230.

Wilce, R. T., 1959. The marine algae of the Labrador Peninsula and Northwest Newfoundland (ecology and distribution). - Bull. natn. Mus. Can. 158, 1-103.

Womersley, H. B. S, 1965. The Helminthocladiaceae (Rhodophyta) of Southern Australia. - Aust. J. Bot. 13, $451-487$.

Womersley, H. B. S., 1967. A critical survey of the marine algae of Southern Australia II. Phaeophyta. - Aust. J. Bot. 15, 189-270.

Womersley, H. B. S. \& Bailey, A., 1970. Marine algae of the Solomon Islands. - Phil. Trans. R. Soc. (B) 259, 257-352.

Zaneveld, J. S., 1972. The benthic marine algae of Delaware, U.S.A. - Chesapeake Sci. 13, $120-138$.

Zaneveld, J. S., 1976. The marine algae of the American coast between Cape May, N.J., and Cape Hatteras, N.C. III. The Phaeophycophyta. - Botanica mar. 19, 33-46.

Zimmermann, M. S. \& Livingston, F. J., 1976. Seasonality and physicochemical ranges of benthic macrophytes from a North Florida estuary (Apalachee Bay). - Contrib. mar. Sci. 20, 33-45.

Zinova, A. D., 1953. Opredel'itel' burych vodoroslej severnych mor'ej SSSR. Izd. Akad. Nauk SSSR, Leningrad, 225 pp. 
Zinova, A. D., 1955. Opredel'itel' krasnych vodoroslej severnych mor'ej SSSR. Izd. Akad. Nauk SSSR, Leningrad, $219 \mathrm{pp}$.

Zinova, A. D., 1967. Opredel'itel' zel'enych, burych i krasnych vodoroslej južnych mor' ej SSSR. Izd. "Nauka", Leningrad, $398 \mathrm{pp}$. 